\title{
WestVirginiaUniversity
}

THE RESEARCH REPOSITORY @ WVU

Graduate Theses, Dissertations, and Problem Reports

2018

\section{A Test of Perseverance: Creating the Scenic Design for The Three Musketeers}

Lindsay Maiorano

Itm0010@mix.wvu.edu

Follow this and additional works at: https://researchrepository.wvu.edu/etd

Part of the Other Theatre and Performance Studies Commons

\section{Recommended Citation}

Maiorano, Lindsay, "A Test of Perseverance: Creating the Scenic Design for The Three Musketeers" (2018). Graduate Theses, Dissertations, and Problem Reports. 3728.

https://researchrepository.wvu.edu/etd/3728

This Thesis is protected by copyright and/or related rights. It has been brought to you by the The Research Repository @ WVU with permission from the rights-holder(s). You are free to use this Thesis in any way that is permitted by the copyright and related rights legislation that applies to your use. For other uses you must obtain permission from the rights-holder(s) directly, unless additional rights are indicated by a Creative Commons license in the record and/ or on the work itself. This Thesis has been accepted for inclusion in WVU Graduate Theses, Dissertations, and Problem Reports collection by an authorized administrator of The Research Repository @ WVU. For more information, please contact researchrepository@mail.wvu.edu. 


\title{
A Test of Perseverance: Creating the Scenic Design for The Three Musketeers
}

\author{
Lindsay Maiorano
}

Thesis Submitted to the College of Creative Arts at West Virginia University

In Partial Fulfillment of the Requirements for the Degree of

\author{
Master of Fine Arts \\ In \\ Scenic Design and Technology
}

Robert Klingelhoefer, Professor of Scenic Design: Chair Steven Neuenschwander, Professor of Technical Direction Cornel Gabara, Professor of Acting

Division of Theatre and Dance

Morgantown, West Virginia

2018

Keywords: The Three Musketeers, Scenic Design, Set Design, Scenery, Theatre Design 


\begin{abstract}
A Test of Perseverance: Creating the Scenic Design for

The Three Musketeers

Lindsay Maiorano
\end{abstract}

This document is an account of the scenic design process for the West Virginia University School of Theatre \& Dance's 2018 production of The Three Musketeers by Catherine Bush. It details the entire scenic design process, including script analysis, research, and design meetings, as well as the processes of construction, scenic art, and technical rehearsals. It illustrates the transformation of a series of renderings and models, which ultimately evolved to the finalized version of the scenic design. 


\section{Dedication}

For my parents, Theresa and Michael Maiorano.

Words truly cannot express how grateful I am for your endless love and support. I am so blessed to have parents that encouraged my creativity throughout my entire upbringing. It is because of you that I am the artist and person I am today. Graduate school was truly a wild ride, and you were there for me every step of the way on this unexpected, cross-country, rollercoaster of a journey.

You selflessly moved mountains just so that I could pursue my dreams. I can never thank you enough.

I am forever in your debt-both figuratively and literally. 


\section{Acknowledgements}

To my family - thank you for your tireless faith in me and for traveling long distances to support my work. Everything you do for me means the world to me.

Thank you to the faculty and staff of Tyler School of Art at Temple University for helping me to explore my passions, grow as an artist, and develop the courage to be vulnerable in my work.

Thank you to the faculty and staff of the theatre department of California State University Long Beach for shaping the beginning of my journey as a graduate student. Thank you especially to Danila Korogodsky, Francois-Pierre Couture, and Hazel Kuang for teaching me to be unafraid to push boundaries and make waves - I will never forget to "fight for my design dreams." I am thankful to have a network of support on the west coast, and I cannot wait to see you again.

Thank you to the fellow students who worked on this production of The Three Musketeers, particularly Nicholas Skiba and James Raymond.

Nick, your relentless determination to see a project through to the end is truly admirable. Your endurance and contagious laughter inspired me to keep going during the late nights in the shop when I just wanted to drop dead. I sincerely hope for the opportunity to work with you again in the future.

James, it is because you encouraged me to look into the URTA interviews four years ago that I ended up pursuing my MFA degree in the first place. It is also because of you that I was able to transfer into a program that enabled me to flourish as an artist and challenged me to grow as a designer. I love you, brother. "I'Il see you on the field!"

Thank you to the West Virginia University School of Theatre \& Dance faculty and staff for giving me this opportunity. A special thanks to Cornel Gabara, for your collaborative spirit.

Thank you to Steven Neuenschwander-it does not go unnoticed that you have your students' best interests in mind at all times and genuinely want us to succeed in our endeavors. Thank you so much for looking out for me and for helping my crazy design dreams come true. The world needs more Technical Directors like you, and I feel incredibly lucky to have been able to learn from you.

Finally, I would like to thank my mentor and dear friend, Bob Klingelhoefer. I cannot thank you enough for accepting me into your program and for always encouraging my ideas and dreams. Your faith in me over the past two years has strengthened my confidence in my design abilities and enabled me to learn so many skills that I never thought I would be capable of. You are truly a brilliant teacher, as well as a gifted "part-time therapist." Words cannot begin to express how proud I am to have been your student, and how blessed I feel to have made a lifelong friend. Thank you so much for your constant support and invaluable wisdom. I believe that your passion for your craft is the heart of our design program-our theatre school is a magical place because of you, and I am forever thankful that my journey led me to WVU. 


\section{Table of Contents}

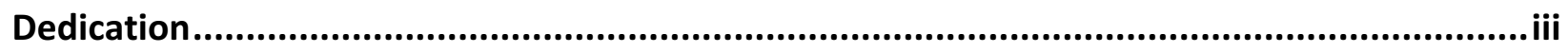

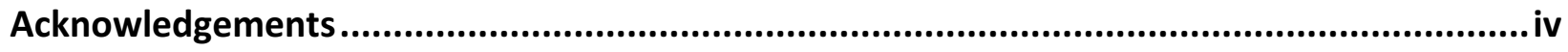

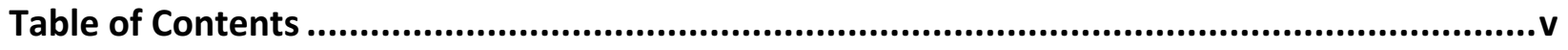

Table of Figures ................................................................................................................ vi

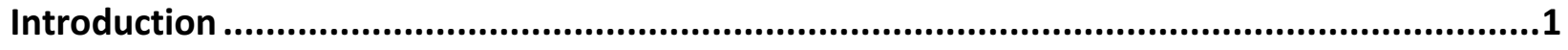

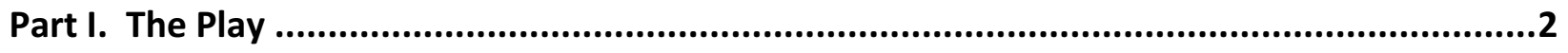

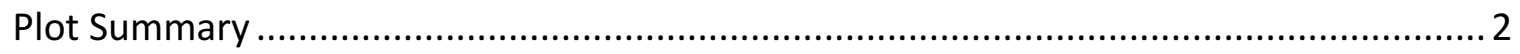

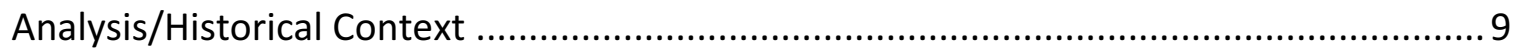

Initial Design Meeting/First Conversation with the Director ................................... 11

Part II. The Design Process ........................................................................................... 13

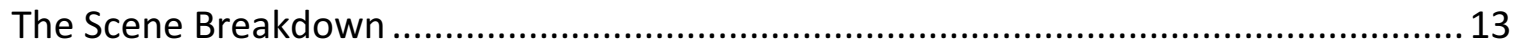

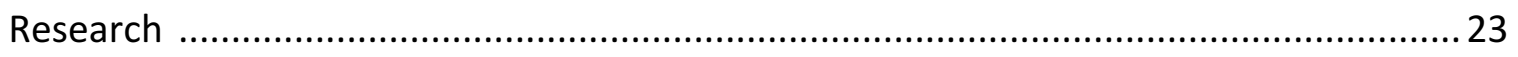

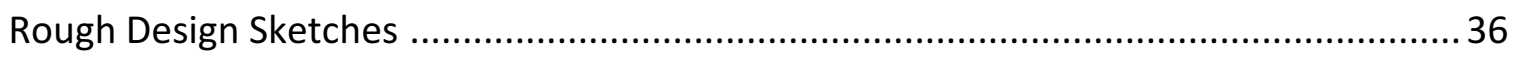

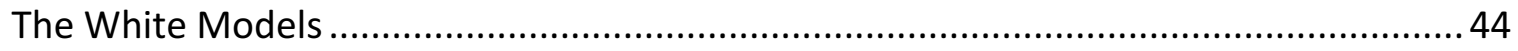

The Drafting Process ..................................................................................... 48

The Last Pieces: Conceptualizing "The Magic Doors" and "The Hanging Crest" ............ 51

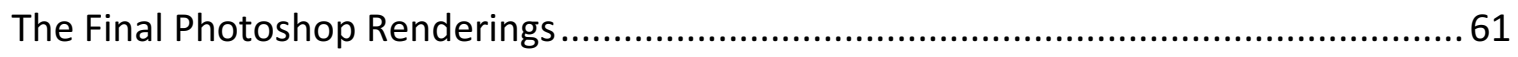

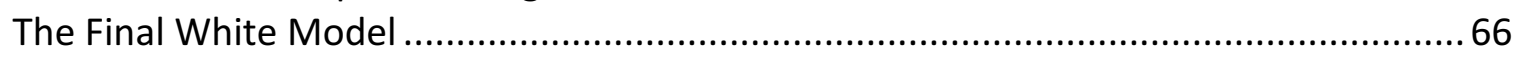

Part III. Design Execution .............................................................................................70

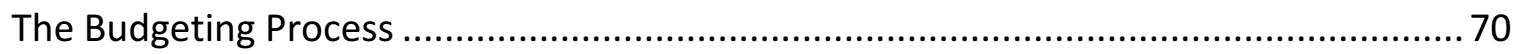

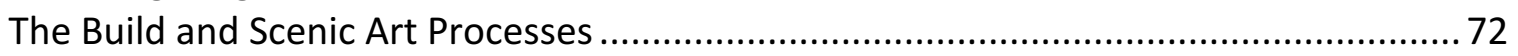

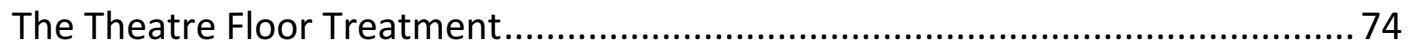

Constructing and Painting the Wagons......................................................... 79

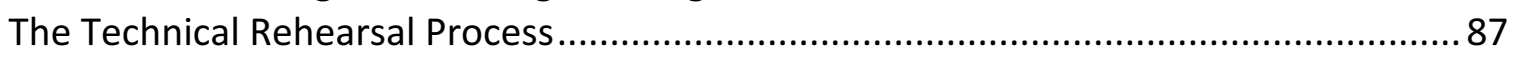

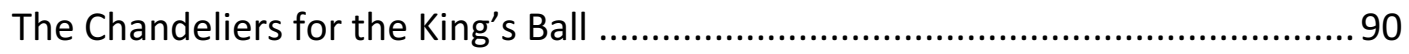

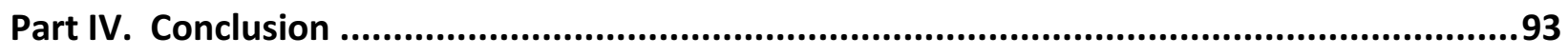

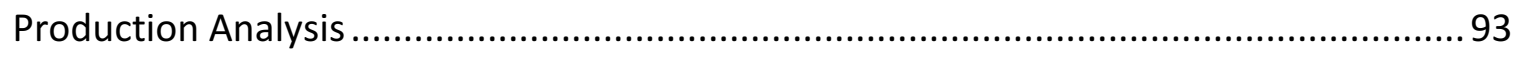

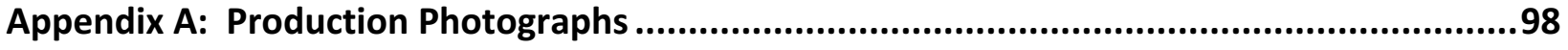

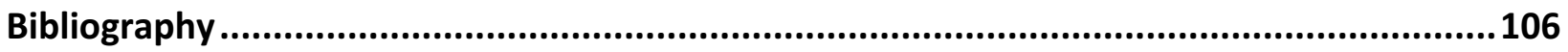




\section{Table of Figures}

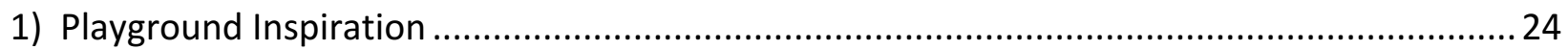

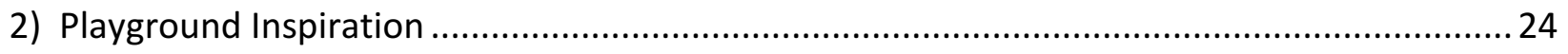

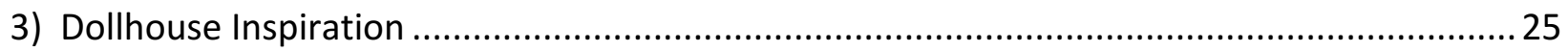

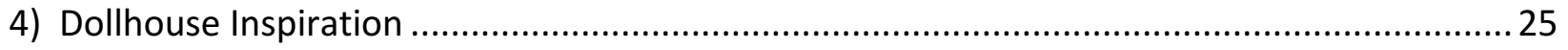

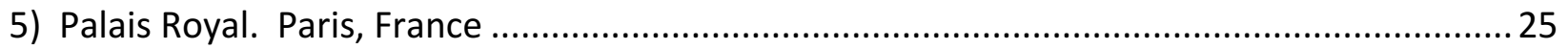

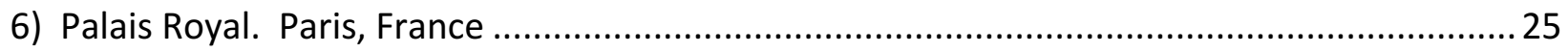

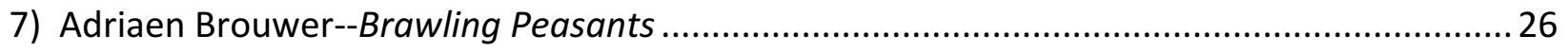

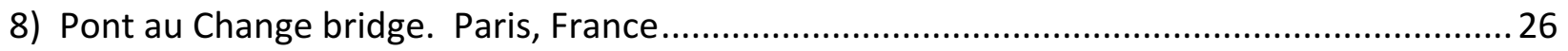

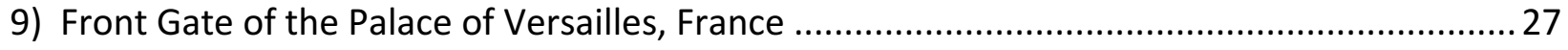

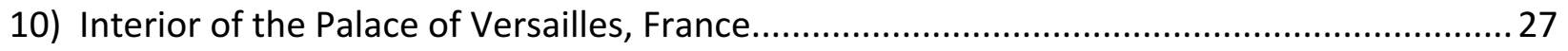

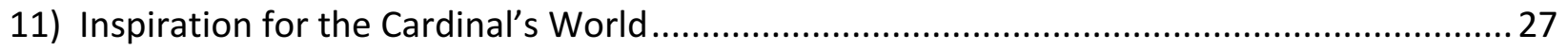

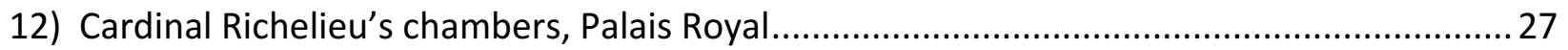

13) Philippe de Champaigne-Portrait of Armand-Jean du Plessis, Cardinal Richelieu ............... 28

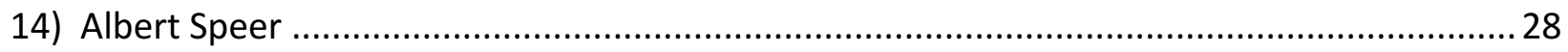

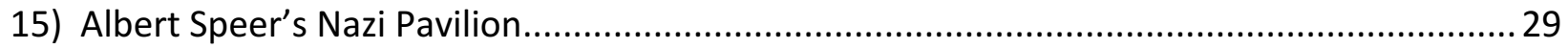

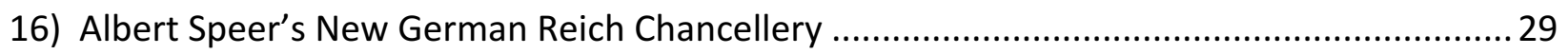

17) Collage for the Musketeers'/Earthlings' World Inspiration ................................................ 31

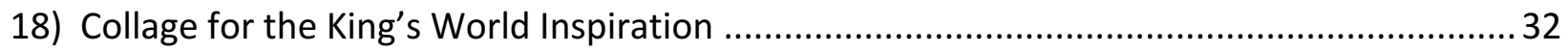

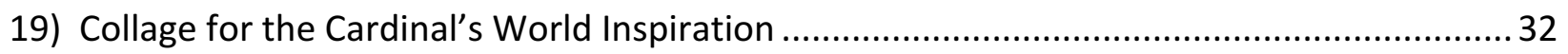

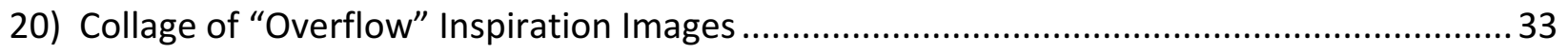

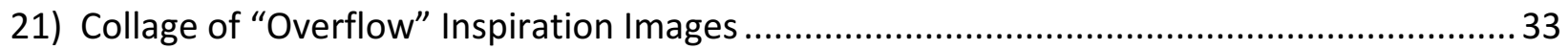

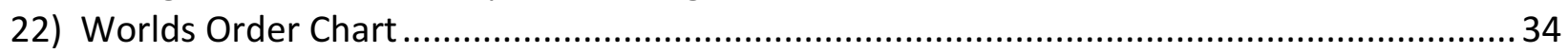

23) Edited Collage for the Musketeers'/Earthlings' World Inspiration ........................................ 35

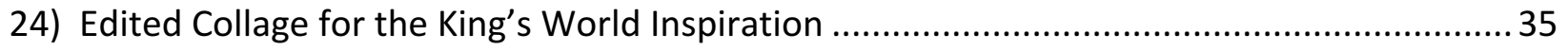

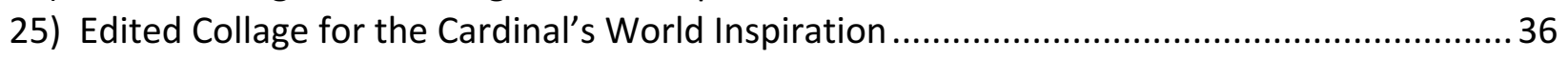

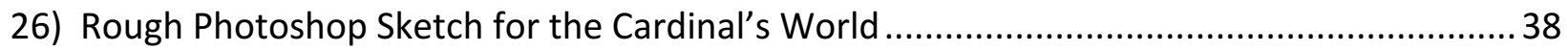

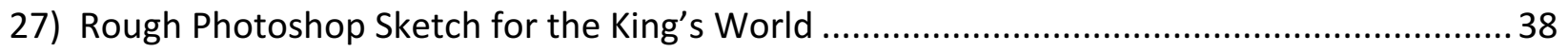

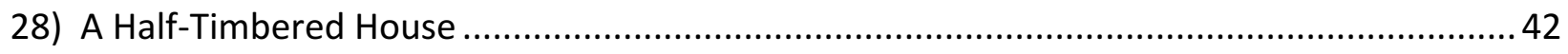

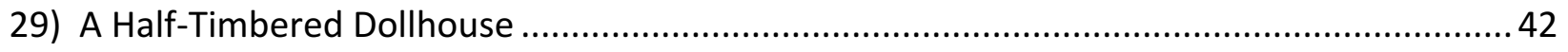

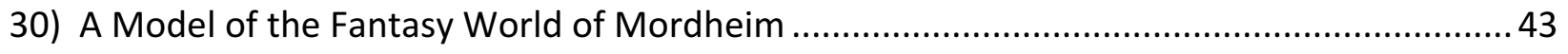

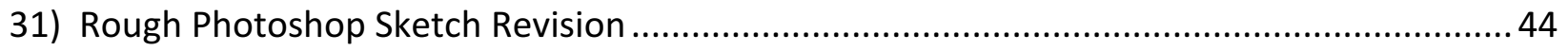

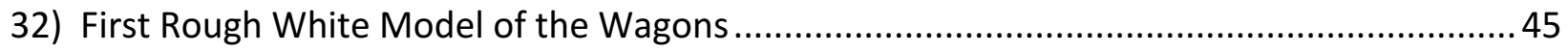

33) Refined White Model .................................................................................................. 47

34) An In-Process Updated Photoshop Rendering of a Possible Cardinal's World...................... 52

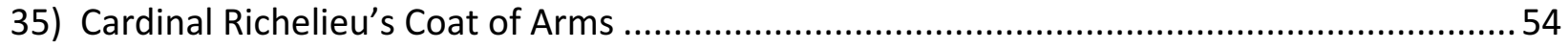

36) Coat of Arms for King Louis XIII and Cardinal Richelieu .................................................... 54

37) A Rough Vectorworks Sketch of My Own Design for the Hanging Crest............................... 54

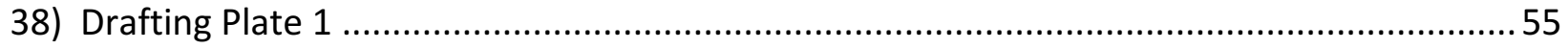

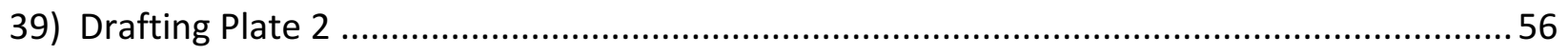

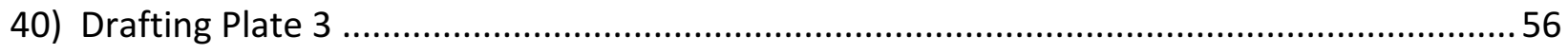




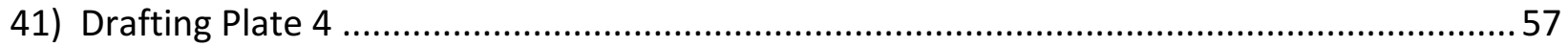

42) Drafting Plate 5

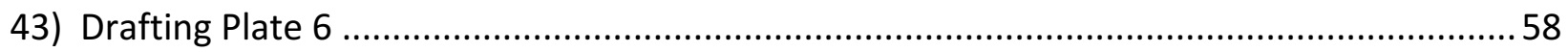

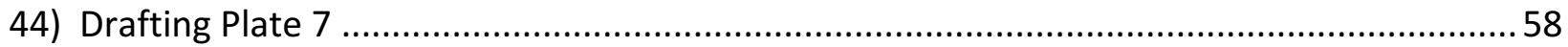

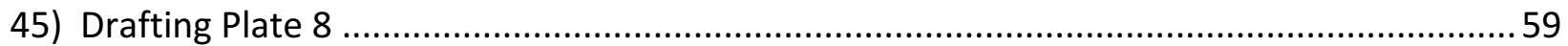

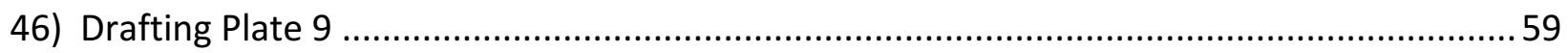

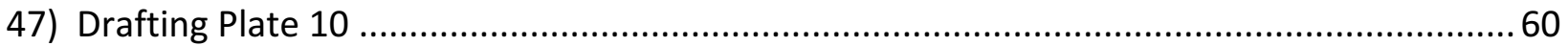

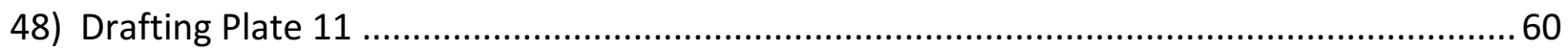

49) An In-Process Photoshop Rendering of a Slightly-Updated King's World ............................62

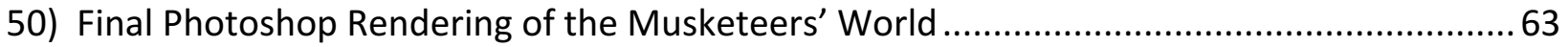

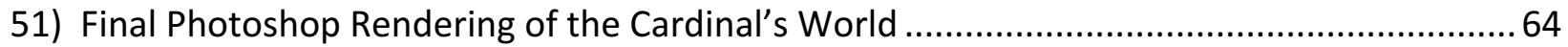

52) Final Photoshop Rendering of the Positioning for the "Neutral" Brown Doors Look ............64

53) Final Photoshop Rendering Depicting Potential Asymmetrical Wagon Positioning...............65

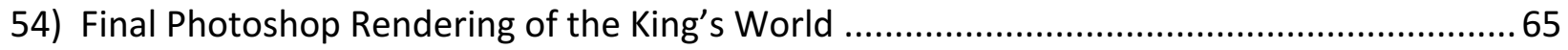

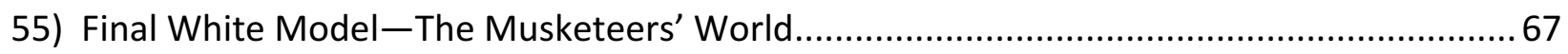

56) Final White Model-The "Neutral" Brown Doors Look.......................................................67

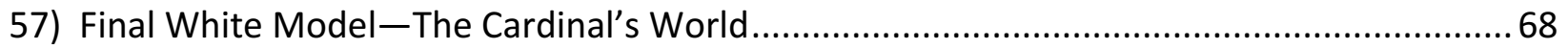

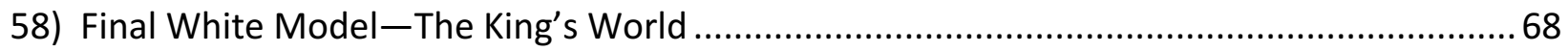

59) The Chandeliers I Borrowed for the King's Ball Scene........................................................... 72

60) Digital Paint Elevation of the Abstracted Map Floor Treatment ........................................ 75

61) Mixed Paint Colors for the Floor Treatment ……............................................................... 75

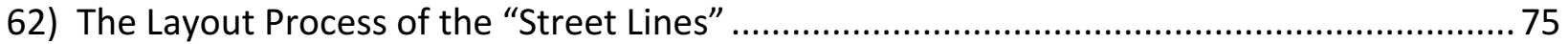

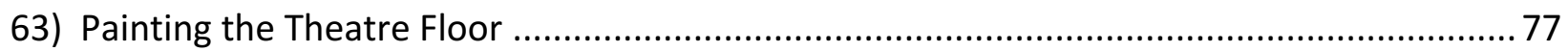

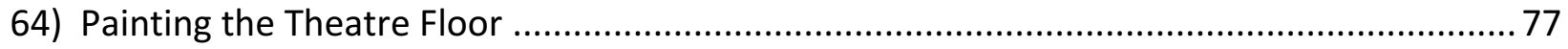

65) Front View of the Completed Floor Treatment............................................................. 78

66) Stage Left View of the Completed Floor Treatment ......................................................... 78

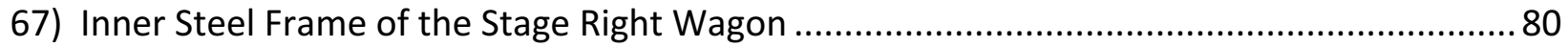

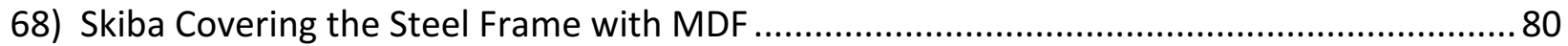

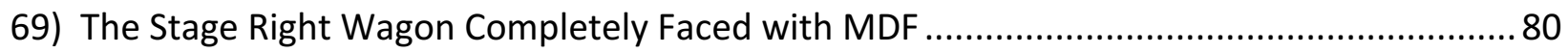

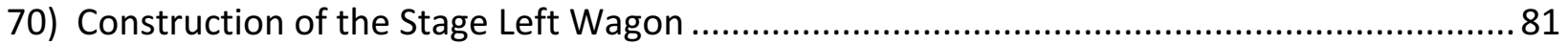

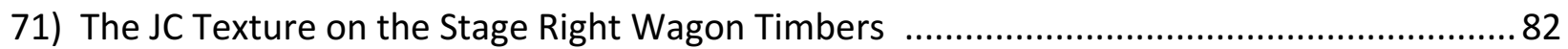

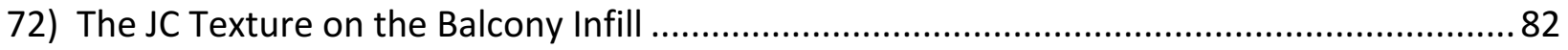

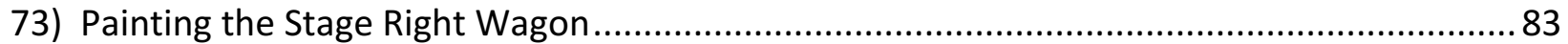

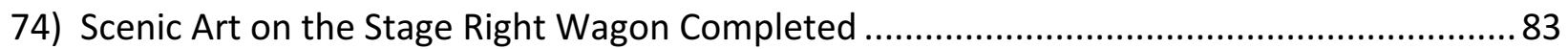

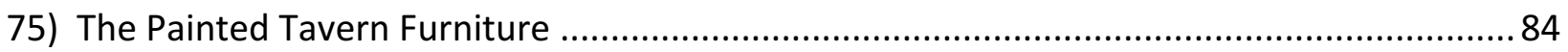

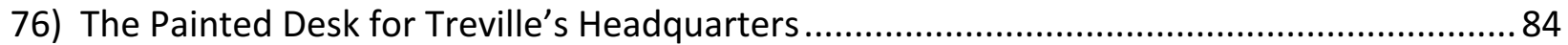

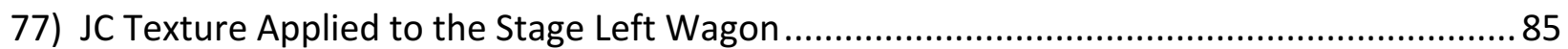

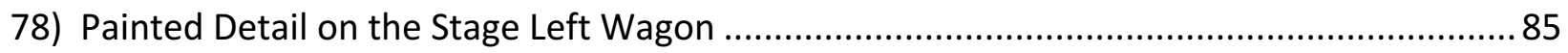

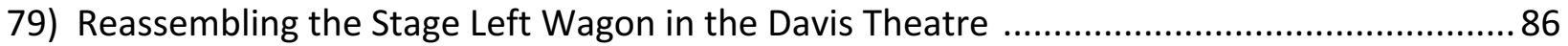

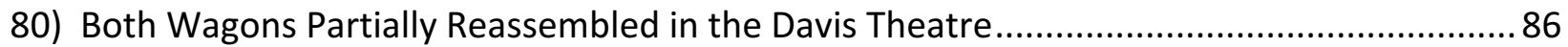

81) Raymond Applying the Gilded Trim Decals to the King's Doors.......................................... 89 


\section{Introduction}

In the spring of 2018, I was assigned the scenic design of the third and final show of the semester to fulfill my thesis requirement, which was to be The Three Musketeers by Catherine Bush. The show was scheduled to open mid-April in the Gladys G. Davis Theatre in the Creative Arts Center of West Virginia University. The Director was Professor Cornel Gabara, with Lighting Design by graduate student Thomas Gillette, Costume Design by Professor Mary McClung, Sound Design by Professor Alan McEwen, and Props Design by Professor Robert Klingelhoefer and his Stage Properties class. My scenic design was realized by senior undergraduate Technical Director Nicholas Skiba.

It was common knowledge that The Three Musketeers was specifically chosen by the Season Selection Committee for the purpose of granting our school's actors the chance to develop skills in stage combat.

Initial design conversations and meetings began just prior to the end of the fall semester in December 2017 so that each collaborator could begin his or her respective preliminary work over the university's winter break. The design deadline was originally scheduled for Friday, January 26, 2018.

This thesis describes the development of the concept, with a detailed account of the design process (focusing on the scenic design), the pre-production construction and scenic art processes, and the culmination of all of these endeavors contributing to a realized production. It also evaluates the preliminary processes and final product as a whole. 


\section{Part I. The Play}

\section{Plot Summary}

The year is 1628 , and the show opens with a criminal running through the streets of Paris, pursued by an angry mob. Young d'Artagnan, a country boy that has only just arrived to the city, intercepts the action, demanding that the man be proven guilty before punished. Rochefort (whom we later find out is a spy for the corrupt Cardinal Richelieu) enters the scene and the two draw swords. They begin to parry and d'Artagnan reveals that he has a letter for Monsieur de Treville, captain of the King's musketeers. D'Artagnan wishes to become a musketeer himself. Milady de Winter enters and bludgeons d'Artagnan with her heavy purse, enabling Rochefort to steal the letter. Rochefort gives Milady an envelope from Richelieu containing instructions for her next assignment, which is to take place in London, and the two hurry their separate ways. When he comes to, d'Artagnan panics at the theft of the letter but heads off to see Treville regardless.

The scene switches to Treville's headquarters and Cardinal Richelieu enters. He warns Treville that he has found out that the infamous three musketeers (Porthos, Athos, and Aramis) were caught dueling in a tavern brawl and that they, and Treville, will be imprisoned in the Bastille if they illegally fight in public again. Treville instructs his assistant, Planchet, to bring the three musketeers into his office and they reenact the fight as a fascinated d'Artagnan watches from the corner. Treville forgives them as he realizes that the King's guards instigated the incident by drawing their swords first. The musketeers are dispatched from the office to seek medical attention for a wound in Athos's shoulder and d'Artagnan makes his presence known once again to Treville. He is finally able to gain Treville's trust without a letter of introduction 
by disclosing details of Treville's childhood friendship with his father, but Treville is firm in that d'Artagnan must prove himself worthy to become a musketeer. D'Artagnan mentions that he overheard Treville exclaim his wishes for someone to "rip the cardinal's ring off his fat finger" (The Three Musketeers, 1.2) and volunteers for the task. Treville brushes the comment off and sends d'Artagnan to Monsieur Bonacieux to seek lodging.

As d'Artagnan rushes through the streets, he passes the three musketeers and accidentally jostles Athos's wounded shoulder. Athos attempts to duel with d'Artagnan, who first offers him a vial of healing potion from his province. Athos's shoulder heals instantly, and they once again attempt to duel. They are interrupted by the pesky Cardinal's guards, and a fight ensues once more. D'Artagnan fights alongside the three musketeers and assists their victory in the brawl, therefore gaining their trust.

D'Artagnan reaches Bonacieux's lodge and experiences love at first sight when Bonacieux's daughter, Constance, enters. Constance is a linen maid and confidante of the Queen, and she mentions that she has a letter from the Queen that must secretly be delivered. D'Artagnan offers to take on the dangerous task of delivering the letter to her secret lover, the Duke of Buckingham. The scene then shifts as Queen Anne and Buckingham have a private rendezvous. Queen Anne thinks their affair is too dangerous to continue because she knows Richelieu had seen the pair together in the past. She urges Buckingham to leave for England and sends him off with a box containing a gift to remember her by.

The scene shifts to Cardinal Richelieu's chambers. Rochefort enters and tells the Cardinal that his spies have witnessed the interaction between Queen Anne and Buckingham. Rochefort also knows that the gift in the box was a set of twelve diamonds attached to a sash 
that King Louis had given to Queen Anne for her birthday. Rochefort urges Richelieu to break the news to the King, but the Cardinal insists it must be brought to his attention delicately. King Louis enters, and Richelieu slyly convinces him to throw a ball for the Queen to lift her spirits and to encourage her to wear the diamond set to show it off. Realizing that the Queen might have time to write to Buckingham and have the diamonds sent back, Richelieu recalls that Milady de Winter is still in London. He instructs her to throw a ball and invite Buckingham as a guest of honor, knowing that he would wear the diamond set to honor his love. Milady is also instructed to steal two diamonds from the sash whilst dancing with him, and to return the diamonds to Richelieu personally. Rochefort is ordered to station spies in every tavern and inn along the coast to ensure that no one gets to Buckingham before the ball.

The scene shifts as d'Artagnan and his new friends, the three musketeers, drunkenly stumble into his room in Bonacieux's house. Constance urgently knocks on the door and enters with a letter from the Queen that must be delivered to Buckingham in haste. The women have found out about Richelieu's scheme, and the letter contains a warning of the upcoming ball and asks for the diamond set to be returned to France. The musketeers volunteer to accompany d'Artagnan on the mission to England.

The four men stop at an inn along the coast of France on their way to catch a ship to England. It turns out the place is full of Richelieu's spies, and a bar brawl ensues. Amid the excitement, Athos convinces d'Artagnan to slip out the door to catch the ship while the musketeers handle the spies. 
D'Artagnan reaches Buckingham and convinces him to give him the diamond set. Whilst taking one last look at the sash, d'Artagnan points out that two of the twelve diamonds have been stolen.

The night of the King's ball arrives, and Richelieu privately gives the two stolen diamonds to King Louis, claiming that they were found in England. King Louis confronts Queen Anne, who reveals that she does in fact have twelve diamonds on her sash, and the two Richelieu has makes fourteen altogether. D’Artagnan tells Constance that Buckingham had two duplicates made in haste before the ball. D'Artagnan and Constance schedule a secret rendezvous for the following night, and d'Artagnan gives her his wallet bearing his family crest as a token of his love. It is then made apparent that Richelieu has been spying on this exchange and is aware of their plans.

Back in d'Artagnan's room, he and the musketeers celebrate their victory in retrieving the diamonds. D'Artagnan asks Athos if he has ever been in love. Athos goes on to drunkenly reveal that he was married once, but his wife insisted on only making love in the dark and he obliged her. On a hunting trip, she was knocked unconscious when she was thrown from her horse. He cut her sleeve away to check for more injuries and discovered a fleur-de-lis brand on her shoulder: the mark of a murderer. He abided by the law and hanged her from the nearest tree.

D’Artagnan leaves for his rendezvous with Constance, and the scene shifts to Constance awaiting his arrival in the streets of Paris. She gives a beggar a coin from the wallet and another figure enters the scene. It is not d'Artagnan, but Rochefort. He drags Constance away, threatening to throw her in the Bastille, and she drops the wallet in the struggle. D'Artagnan 
then enters the scene and finds the wallet on the ground. He gets as much information about the incident as he can from the beggar and swears that he will find her. There is then a blackout and act one concludes.

Act two begins with d'Artagnan and the three musketeers arguing about Constance's situation in Treville's headquarters. D'Artagnan wishes to risk his life to break Constance out of the Bastille, but Treville informs him that she has been relocated. It turns out that Planchet's lover, Kitty, is Milady de Winter's maid and has overheard this information. Treville tells the men they must flee Paris to lie low for a little while, as it is probable that Richelieu will try to avenge his humiliation for the diamond scandal. The musketeers head off in separate directions, planning to regroup in Amiens. After they depart, d'Artagnan implores Planchet and Kitty for access to Milady de Winter's chambers to search for clues of Constance's whereabouts. They oblige, and he disguises himself and begins to search the room. Milady de Winter returns to her abode while d'Artagnan is still inside. She believes he is Rochefort and places a medallion around his neck. She says it once belonged to a man that loved her, but she is now giving it to the one she loves. Eventually she realizes that he is not Rochefort and the two begin to fight. D'Artagnan rips her sleeve and sees a fleur-de-lis brand on her shoulder. Milady de Winter manages to injure him, and he narrowly escapes her chambers. The scene shifts to Richelieu's chambers.

Richelieu admonishes Rochefort for losing track of the musketeers. Milady de Winter requests permission to kill d'Artagnan herself, but Richelieu denies her permission and instead wants her to assassinate Buckingham in England. Afterwards, she is to hide in a convent in Bethune and await further instructions. Richelieu reluctantly agrees to let her kill d'Artagnan in 
the convent (Rochefort will bring him to her) after she kills Buckingham. She requests a written order from Richelieu as a safeguard in case she is caught which states that she was given his permission to take action on behalf of France. Milady de Winter also reveals that she has a vial of poison.

Meanwhile, the musketeers have been waiting for d'Artagnan's arrival for two worrisome weeks. Porthos and Aramis are convinced that d'Artagnan is dead. Suddenly, d'Artagnan knocks on their door and staggers inside. He fills them in regarding the attack in Milady de Winter's chambers and gives them the medallion she had placed around his neck. Athos admits that the medallion bears his family crest and realizes that Lady de Winter was his former wife, who had somehow survived the hanging. Planchet also arrives and informs them that Constance had been imprisoned at Nantes, but the Queen's influence rescued her. She is now hiding in a convent in Bethune, disguised as a nun. Richelieu's spies suddenly enter the room and Planchet shocks everyone in the room by taking them all down singlehandedly.

The scene shifts to the convent in Bethune, where the abbess is showing Milady de Winter to her room. During small talk, the abbess inadvertently reveals Constance's true identity to Milady de Winter before sending Constance into the room with a tray of food and wine. Milady tricks Constance into trusting her enough to confirm that she is not a true nun and is in fact d'Artagnan's lover. Milady pours the vial of poison into the glass of wine and offers it to Constance. Constance hears the sounds of d'Artagnan's and the musketeers' horses approaching, and Milady threatens her with a knife from the table. Constance finally realizes Milady works for Rochefort and Richelieu, and the two fight. Milady succeeds in pouring the poisoned wine down Constance's throat and escapes. By the time d'Artagnan and the 
musketeers reach her side, it is too late to save her. She musters enough strength to tell them that Milady de Winter poisoned her and dies in d'Artagnan's arms. Athos sets off to find Milady de Winter.

Milady is in an inn on the coast of France, planning to sail out on the next ship to England. Athos sneaks into the room to confront her. She tries unsuccessfully to convince him that she is innocent and her actions were within the law. She kisses him and attempts to stab him but is unsuccessful, and Athos snaps her neck.

Back in Paris, Treville offers his condolences to d'Artagnan for Constance's death. Planchet informs them that Buckingham was assassinated by a fanatic that claimed he committed the murder for Milady de Winter's love. Athos returns and gives d'Artagnan the written order Milady had obtained from Richelieu.

D'Artagnan heads to his lodge to inform Bonacieux about his daughter's death. He realizes that Rochefort is behind Bonacieux, holding a knife plunged into Bonacieux's back. Rochefort states that he intends to avenge Milady's death. The two fight, and d'Artagnan wins. Richelieu and his soldiers arrive at the lodge to arrest d'Artagnan for dueling in public. D'Artagnan argues that he is not in public, but in a private residence and flaunts the written order he possesses in Richelieu's handwriting. Richelieu demands him to give him the written order. D'Artagnan tells him he will only exchange it for Richelieu's precious ring. The two trade their respective items.

The scene shifts to Treville's headquarters. D'Artagnan has given Richelieu's ring to Treville and fulfills his dream of becoming a full-fledged musketeer. The three musketeers congratulate d'Artagnan, but then admit that they are retiring to pursue other endeavors. 
Suddenly, Planchet runs in and announces that the Queen has been kidnapped by bandits en route to Germany. The three musketeers decide to band together with d'Artagnan for another adventure. The show concludes with the four musketeers exclaiming, "All for one, and one for all!" (The Three Musketeers, 2:9)

\section{Analysis/Historical Context}

Upon my first reading of the script, the main thing that stood out to me was that it wasn't very profound or substantial; it felt instead like a mound of "fluff." A hearty portion of the dialogue itself throughout the entire script is comprised of exposition, which was somewhat exhausting to read; most of the action was described by the characters verbally instead of actually occurring onstage. This made the entire script feel very rushed. It was as if the author was so desperate to tie up all of the loose ends to an already shallow plot by cramming as much (arguably unnecessary) detail into a 90-minute script as possible. In my opinion, the actual writing style of the script itself was lackluster, underwhelming and elementary; I could easily imagine this show being perfectly suitable for a production at a middle school, but here we were, about to perform this script in a university setting. That being said, I didn't feel as if there was anything much to analyze, though I did attempt to glean as much substance out of it as possible. Conversely, I will say that although it lacked the profundity I am often accustomed to enjoying in our school's typical season selections, it was, in a way, a refreshing break to work on a project that was lighthearted and not so heavy.

I had already been aware that there are several versions of The Three Musketeers in existence in both theatre and film, including two different Disney films that released in 1993 and 2004 , so I began by researching the historical context of the original version The Three 
Musketeers by French author Alexandre Dumas. I found that although it is today regarded as a novel, it turns out that it was originally not published in traditional novel format-it instead began as a series of episodes published in a Parisian magazine called Siecle in 1844. Each time a new issue of the periodical was released, it featured the next segment of Dumas's story. It quickly gained popularity amongst the French public, who would form long lines to obtain each new issue.

The Romanticism movement that had originated in Europe was at its peak as Dumas created The Three Musketeers. At the time of its release, $19^{\text {th }}$ century France was in turmoil because it was suffering the aftermath of the French Revolution. Dumas made the brilliant move of combining the two existing genres of Historical Novel and Romance to create a story that gifted its readers with pure escapism. This escapist work was also written in a modern voice, and its publication in Siecle made it a more accessible work than those of his predecessors. While the story contained characters based on actual historical figures, such as Cardinal Richelieu, and was based on $17^{\text {th }}$ century France, it was still an adventure that was purely fictional. However, its depiction of France also helped to promote a rekindled sense of national pride in its audience, at a time when it was much needed. It idealized the nation's history whilst omitting any details that might have struck a nerve in its readers. In other words, The Three Musketeers is a significant piece of literature because it is entertaining and fun, and it continues to live on today, in several different versions and media. Having understood this, I started to ease up a little bit on my critical opinion of Catherine Barter's script. To this day, I am still not necessarily a fan of her writing style or that particular script because I feel it does not 
do justice to Dumas's sentimental masterpiece, but I did try to have more of an appreciation of the fact that her script was purely "fun."

\section{Initial Design Meeting/First Conversation with the Director}

During my first meeting with director Professor Gabara, I discovered that his initial reaction to the script basically echoed mine; I believe his exact phrasing was that the script is "nothing special," and it was up to his direction and our overall interpretation to make the show worthwhile both for university-level actors to work on, as well as for a university-level audience to enjoy. He mentioned that conceptually, the energy of light-hearted live-action adventure movies should serve as our inspiration, and suggested that I take a closer look at films such as the Disney version of "The Three Musketeers," "The Mask of Zorro," and "The Princess Bride." He also mentioned that our production would focus on the city of Paris through d'Artagnan's eyes. Having just arrived from the country, d'Artagnan is a young, ambitious hero in a "fish out of water" situation, and Paris should seem like a vastly different world than his hometown. Paris should seem like a complex and complicated world in which the musketeers are guardians. The staged fights between the characters would be "dirty."

In terms of design, he visualized there being a push and pull between "dirty" and "clean" between the physical spaces and costumes of the musketeers/villagers and that of the pristine King and Cardinal and their guards. It was during this conversation that we also started putting heavy emphasis on the depiction of color-coded "Worlds," and this became the primary idea that served as the driving force behind my own research later on. He visualized the King's World as purple (primarily because purple is the indicator of royalty), the Cardinal's World as red (for both the color of the Cardinal's robes and the color's stereotype as powerful and 
dangerous), and the Musketeers/Villagers' World as a mixture of blue (for the color of their tabards) and earth tones (to represent class of a lower status).

Professor Gabara imagined the set to be very physical and enable spectacle, with varying levels to simulate a hierarchy, with an implication of divinity at the uppermost level. He also imagined there to be a strong sense of verticality in the King's World and Cardinal's World. The challenge for me as a scenic designer for the latter worlds was to make it clear that the King and Cardinal operated in the same physical space, but I wanted each space to have a slight variance to echo their different motives and/or perceptions. Professor Gabara mentioned that he wanted to show elements of kinkiness in Richelieu's scenes to highlight his corruptive tendencies and hypocrisy. He used an analogy to inspire the differentiating look of the King's World as being "like a Christmas tree with one too many ornaments." The Duke of Buckingham and Milady de Winter would also be somewhat associated with these worlds, and he used an analogy that these characters were "in the same hotel, but in different rooms" as the King and Cardinal.

The script calls for very swift transitions, so we also knew it was crucial for the scenic transitions to be performed quickly as to not disrupt the story. We assumed the actors would perform the fluid transitions in front of the audience to promote the sense of presentational theatricality. We also knew that whatever the set ended up looking like, it was of utmost importance that the set itself be conducive to stage choreography. 


\section{Part II. The Design Process}

\section{The Scene Breakdown}

When I am working on a show that calls for multiple location shifts and/or swift transitions, I will often create a chart that scene designers refer to as a Scene Breakdown. This type of chart can be altered to include any specific information that will aid the designer depending on the circumstances of a show, but I generally include more or less the same information each time.

The chart I created for The Three Musketeers specified each act and scene number in chronological order, followed by columns specifying particular locations and the names of the characters in each scene. This helped me to get my thoughts in order to see how much of a location transition (if any) was necessary between scenes as the show progressed, as well as to keep track of how many actors were going to be onstage at a time.

I then added a column labeled "Description" so that I could keep track of the events that take place in each scene. This helped me to become accustomed to the flow of the story and was also helpful because it served as a quick reference source that eliminated the need of having to flip through the entire script to take a closer look at a certain scene.

The "Implied Set Pieces \& Props" column was where I would make a note of what objects were necessary for each scene, especially if an object is mentioned in the dialogue. For example, if it is evident in the script that a character is drinking, it is pretty obvious that a mug or tankard of some sort should probably be present onstage, but that also opens up the possibility for other objects to be onstage-is there a table or surface of some sort that the character sets the prop on, or does he hold it for the entirety of the scene? Those types of 
questions are the reason that I include the phrase "Implied Set Pieces" as the title of that column. These are set pieces that are not necessarily mentioned in the dialogue, but I can consider adding into the look the scene, or prepares me in advance for set pieces that the director might add into that moment at his discretion. If a scene takes place in a tavern, it becomes slightly safe to assume that a director may expect or request tables and stools, unless it is for whatever reason agreed upon that they are not completely necessary to imply a tavern mood. This column in the chart was very helpful in this design scenario because any furniture or props brought onstage at any given time had to factor into the flow of the transitions.

The last column in my table is entitled "Other Notes", which is where I specified moments between scenes that were faster or more drastic in their location changes, as well as recorded any personal reactions I had in terms of the mood of a certain scene, or anything else I wanted to keep in mind as I began to design.

Upon completing this chart, I scheduled a meeting with Professor Gabara so that we could talk through the needs of each scene, and I adjusted the "Implied Set Pieces \& Props" column accordingly throughout our discussion. We also compared our own reactions regarding the mood of each scene. Following our conversation, I provided him with a copy of this chart to ensure that we remained on the same page.

The next few pages show a copy of the actual Scene Breakdown I created for this process. 
THE THREE MUSKETEERS SCENE BREAKDOWN

\begin{tabular}{|c|c|c|c|c|c|}
\hline Act: Scene & Location & Characters & Description & $\begin{array}{l}\text { Implied Set } \\
\text { Pieces \& Props }\end{array}$ & Other Notes \\
\hline $1: 1$ & Street in Paris & $\begin{array}{l}\text { Criminal, } \\
\text { d'Artagnan, } \\
\text { soldiers, } \\
\text { Rochefort, } \\
\text { Milady De } \\
\text { Winter }\end{array}$ & $\begin{array}{l}\text { D'artagnan tries } \\
\text { to defend a } \\
\text { criminal, duel } \\
\text { begins between } \\
\text { d'Artagnan and } \\
\text { Rochefort, } \\
\text { Milady knocks } \\
\text { him out with her } \\
\text { purse and they } \\
\text { steal his letter. } \\
\text { He wakes up } \\
\text { after the other } \\
\text { two flee the } \\
\text { scene. }\end{array}$ & $\begin{array}{l}\text { Swords, letter, } \\
\text { heavy purse, } \\
\text { envelope }\end{array}$ & \\
\hline $1: 2$ & $\begin{array}{l}\text { Headquarters of } \\
\text { King's } \\
\text { Musketeers }\end{array}$ & $\begin{array}{l}\text { Planchet, } \\
\text { Treville, } \\
\text { Richelieu, } \\
\text { d'Artagnan, } \\
\text { Jussac, guards, } \\
\text { bar patrons }\end{array}$ & $\begin{array}{l}\text { Richelieu } \\
\text { informs } \\
\text { Planchet of a } \\
\text { duel involving } \\
\text { the } 3 \\
\text { musketeers; } \\
\text { D'Artagnan } \\
\text { introduces } \\
\text { himself to } \\
\text { Treville; } 3 \\
\text { musketeers } \\
\text { enter and } \\
\text { reenact the } \\
\text { tavern duel; } \\
\text { D'Artagnan } \\
\text { gains Planchet's } \\
\text { trust. }\end{array}$ & $\begin{array}{l}\text { Vial of potion, } \\
\text { desk (or implied } \\
\text { desk), pieces of } \\
\text { paper, swords }\end{array}$ & $\begin{array}{l}\text { Transitions } \\
\text { quickly into a } \\
\text { reenacted } \\
\text { flashback at the } \\
\text { tavern, then } \\
\text { back to the } \\
\text { headquarters }\end{array}$ \\
\hline $1: 3$ & Streets outside & $\begin{array}{l}3 \text { musketeers, } \\
\text { d'Artganan, } \\
\text { Jussac and } 3 \\
\text { guards }\end{array}$ & $\begin{array}{l}\text { D'Artagnan runs } \\
\text { into the } 3 \\
\text { musketeers and } \\
\text { ends up fighting } \\
\text { alongside them } \\
\text { when Jussac and } \\
\text { the guards enter } \\
\text { the scene, thus } \\
\text { gaining their } \\
\text { trust. }\end{array}$ & $\begin{array}{l}\text { Vial of potion, } \\
\text { swords }\end{array}$ & $\begin{array}{l}\text { Transitions into } \\
\text { Monsieur } \\
\text { Bonacieux's } \\
\text { house }\end{array}$ \\
\hline
\end{tabular}




\begin{tabular}{|c|c|c|c|c|c|}
\hline $1: 4$ & $\begin{array}{l}\text { Monsieur } \\
\text { Bonacieux's } \\
\text { house }\end{array}$ & $\begin{array}{l}\text { Monsieur } \\
\text { Bonacieux, } \\
\text { d'Artagnan, } \\
\text { Constance, } \\
\text { Buckingham }\end{array}$ & $\begin{array}{l}\text { D'Artagnan } \\
\text { meets Monsieur } \\
\text { Bonacieux when } \\
\text { he arrives to } \\
\text { stay at his place } \\
\text { and falls in love } \\
\text { with Constance } \\
\text { at first sight. He } \\
\text { offers to help } \\
\text { her deliver an } \\
\text { urgent note. }\end{array}$ & Wallet, note & $\begin{array}{l}\text { Transitions into } \\
\text { No. } 75 \text { Rue de la } \\
\text { Harpe, the } \\
\text { address at } \\
\text { which } \\
\text { d'Artagnan is to } \\
\text { deliver the } \\
\text { note. } \\
\text { Constance } \\
\text { narrates the } \\
\text { instructions as } \\
\text { d'Artagnan acts } \\
\text { them out. }\end{array}$ \\
\hline $1: 5$ & $\begin{array}{l}\text { Secret chamber } \\
\text { in the Palais du } \\
\text { Louvre }\end{array}$ & $\begin{array}{l}\text { Buckingham, } \\
\text { Queen Anne, } \\
\text { Constance }\end{array}$ & $\begin{array}{l}\text { Buckingham and } \\
\text { Queen Anne } \\
\text { meet secretly } \\
\text { and we find out } \\
\text { that they are in } \\
\text { love, but Anne is } \\
\text { married to King } \\
\text { Louis and she } \\
\text { says she cannot } \\
\text { see him } \\
\text { anymore but } \\
\text { has a gift for } \\
\text { him to } \\
\text { remember her } \\
\text { by. They are } \\
\text { concerned } \\
\text { about being } \\
\text { caught in } \\
\text { Richelieu and } \\
\text { Rochefort's web } \\
\text { since the } \\
\text { cardinal saw the } \\
\text { two of them } \\
\text { together, and } \\
\text { we find out that } \\
\text { spies follow } \\
\text { Anne } \\
\text { everywhere. }\end{array}$ & Rosewood box & $\begin{array}{l}\text { Feelings of } \\
\text { secrecy, } \\
\text { shadow, being } \\
\text { watched }\end{array}$ \\
\hline
\end{tabular}




\begin{tabular}{|c|c|c|c|c|c|}
\hline 1: 6 & $\begin{array}{l}\text { Richelieu's } \\
\text { chambers }\end{array}$ & $\begin{array}{l}\text { Richelieu, } \\
\text { Rochefort, King } \\
\text { Louis, Milady, } \\
\text { and } \\
\text { Buckingham (in } \\
\text { narration) }\end{array}$ & $\begin{array}{l}\text { Rochefort } \\
\text { reveals that } \\
\text { Buckingham has } \\
\text { left for England } \\
\text { and knows that } \\
\text { the box } \\
\text { contained a set } \\
\text { of } 12 \text { diamonds } \\
\text { that the king } \\
\text { had given to } \\
\text { Anne. They } \\
\text { convince the } \\
\text { king to throw a } \\
\text { ball and insist } \\
\text { that Anne wear } \\
\text { the diamonds. }\end{array}$ & $\begin{array}{l}\text { Handheld } \\
\text { mirror }\end{array}$ & $\begin{array}{l}\text { Transitions into } \\
\text { a narration of } \\
\text { Richelieu's plan } \\
\text { to have Milady } \\
\text { steal some } \\
\text { diamonds from } \\
\text { Buckingham } \\
\text { during the ball }\end{array}$ \\
\hline 1:7 & $\begin{array}{l}\text { D'Artagnan's } \\
\text { room }\end{array}$ & $\begin{array}{l}\text { Anne, } \\
\text { Constance, } \\
\text { d'Artagnan, } 3 \\
\text { musketeers }\end{array}$ & $\begin{array}{l}\text { Transitions into } \\
\text { Anne giving } \\
\text { Constance a } \\
\text { letter, and then } \\
\text { transitions into } \\
\text { d'Artagnan's } \\
\text { room; the three } \\
\text { musketeers are } \\
\text { jolly and singing. } \\
\text { Constance } \\
\text { informs } \\
\text { d'Artagnan that } \\
\text { a letter must be } \\
\text { delivered to } \\
\text { Buckingham } \\
\text { explaining that } \\
\text { Anne needs the } \\
\text { diamonds back } \\
\text { before the ball } \\
\text { in one week. } \\
\text { The musketeers } \\
\text { decide to join } \\
\text { him. Constance } \\
\text { and d'Artagnan } \\
\text { kiss. }\end{array}$ & letter & \\
\hline
\end{tabular}




\begin{tabular}{|c|c|c|c|c|}
\hline $1: 8$ & $\begin{array}{l}\text { Golden Lily Inn, } \\
\text { Calais (the } \\
\text { French coast) }\end{array}$ & $\begin{array}{l}\text { D'Artagnan, } \\
\text { musketeers, } \\
\text { barmaid, } \\
\text { prostitute, } \\
\text { fisherman, } \\
\text { sailors, } \\
\text { innkeeper }\end{array}$ & $\begin{array}{l}\text { Bar feels } \\
\text { sketchy to the } \\
\text { musketeers } \\
\text { upon entering; } \\
\text { it turns out all of } \\
\text { the } \\
\text { workers/patrons } \\
\text { have caught the } \\
\text { musketeers and } \\
\text { d'Artagnan in a } \\
\text { trap. A big } \\
\text { brawl ensues. }\end{array}$ & $\begin{array}{l}\text { Drinks, tables, } \\
\text { chairs/stools }\end{array}$ \\
\hline $1: 9$ & $\begin{array}{l}\text { Buckingham's } \\
\text { study, England }\end{array}$ & $\begin{array}{l}\text { Buckingham, } \\
\text { Braddock, } \\
\text { d'Artagnan }\end{array}$ & $\begin{array}{l}\text { D'Artagnan } \\
\text { gives } \\
\text { Buckingham the } \\
\text { letter; they } \\
\text { realize in horror } \\
\text { that the } \\
\text { diamond set is } \\
\text { missing two } \\
\text { diamonds. }\end{array}$ & $\begin{array}{l}\text { Desk, letters, } \\
\text { rosewood box } \\
\text { with diamonds }\end{array}$ \\
\hline $1: 10$ & $\begin{array}{l}\text { Ball in King's } \\
\text { Palace, France }\end{array}$ & $\begin{array}{l}\text { King Louis, } \\
\text { Richelieu, Anne, } \\
\text { crowd, } \\
\text { Constance, } \\
\text { d'Artagnan }\end{array}$ & $\begin{array}{l}\text { Richelieu alerts } \\
\text { the King that } \\
\text { two diamonds } \\
\text { will be missing } \\
\text { from the } \\
\text { queen's set, and } \\
\text { produces 2 } \\
\text { diamonds that } \\
\text { he claims were } \\
\text { found in } \\
\text { England. Anne } \\
\text { reveals that she } \\
\text { has replaced the } \\
\text { two diamonds } \\
\text { and Richelieu } \\
\text { quickly pretends } \\
\text { he created a } \\
\text { ruse to gift her } \\
\text { with two more } \\
\text { diamonds. } \\
\text { Richelieu } \\
\text { secretly watches } \\
\text { Constance and } \\
\text { d'Artagnan } \\
\text { arrange a secret } \\
\text { rendezvous. } \\
\text { D'Artagnan } \\
\text { gives Constance } \\
\text { his wallet. }\end{array}$ & $\begin{array}{l}\text { Diamonds, } \\
\text { wallet }\end{array}$ \\
\hline
\end{tabular}




\begin{tabular}{|c|c|c|c|c|c|}
\hline 1: 11 & Lodge & $\begin{array}{l}\text { D'Artagnan, } 3 \\
\text { musketeers, } \\
\text { Mystery } \\
\text { Woman? (in } \\
\text { narration) }\end{array}$ & $\begin{array}{l}\text { The musketeers } \\
\text { celebrate their } \\
\text { success with the } \\
\text { diamond } \\
\text { scheme. } \\
\text { D'Artagnan } \\
\text { reveals that he } \\
\text { is in love and } \\
\text { looks at the } \\
\text { moon. Athos } \\
\text { tells the story of } \\
\text { his ex-wife. }\end{array}$ & $\begin{array}{l}\text { Wine glasses, } \\
\text { wine jug }\end{array}$ & $\begin{array}{l}\text { Athos drunkenly } \\
\text { passes out and } \\
\text { d'Artagnan } \\
\text { leaves to meet } \\
\text { up with } \\
\text { Constance } \\
\text { (transitions to } \\
\text { the streets) }\end{array}$ \\
\hline 1: 12 & $\begin{array}{l}\text { Street outside } \\
\text { the bungalow }\end{array}$ & $\begin{array}{l}\text { D'Artagnan, } \\
\text { Beggar, Citizen, } \\
\text { Constance, } \\
\text { Rochefort }\end{array}$ & $\begin{array}{l}\text { Constance gives } \\
\text { a beggar a coin } \\
\text { from the wallet; } \\
\text { shortly } \\
\text { afterwards } \\
\text { Rochefort } \\
\text { abducts } \\
\text { Constance and } \\
\text { she drops the } \\
\text { wallet. The } \\
\text { beggar picks it } \\
\text { up. D'Artagnan } \\
\text { enters the scene } \\
\text { and interrogates } \\
\text { the beggar } \\
\text { when he notices } \\
\text { the wallet. }\end{array}$ & wallet & \\
\hline $2: 1$ & $\begin{array}{l}\text { Treville's } \\
\text { headquarters }\end{array}$ & $\begin{array}{l}\text { Treville, } \\
\text { d'Artagnan, } 3 \\
\text { musketeers, } \\
\text { Planchet }\end{array}$ & $\begin{array}{l}\text { D'Artagnan } \\
\text { pleads for help } \\
\text { in rescuing } \\
\text { Constance. It is } \\
\text { revealed that } \\
\text { Planchet is the } \\
\text { lover of Milady's } \\
\text { maid and he } \\
\text { says that while } \\
\text { Constance is not } \\
\text { in the Bastille, } \\
\text { her location is } \\
\text { still unknown. } \\
\text { Treville urges } \\
\text { the men to flee } \\
\text { Paris to let the } \\
\text { diamond } \\
\text { incident blow } \\
\text { over. } \\
\text { D'Artagnan says } \\
\text { he needs access } \\
\text { to Milady's } \\
\text { chambers. }\end{array}$ & Desk, note & \\
\hline
\end{tabular}




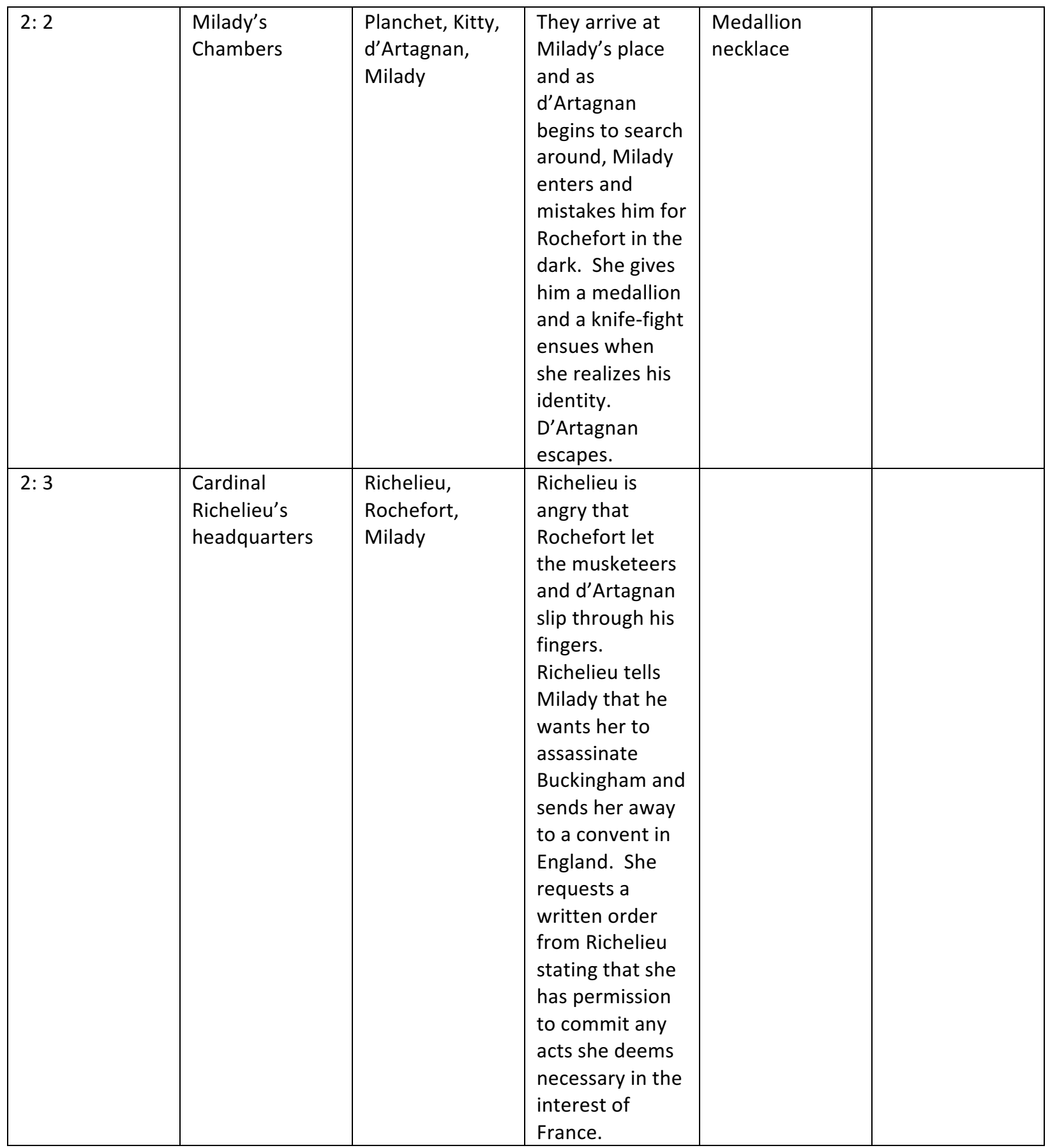




\begin{tabular}{|c|c|c|c|c|c|}
\hline $2: 4$ & $\begin{array}{l}\text { Room in } \\
\text { Amiens, } 2 \\
\text { weeks later }\end{array}$ & $\begin{array}{l}3 \text { musketeers, } \\
\text { d'Artagnan, } \\
\text { Planchet, spies }\end{array}$ & $\begin{array}{l}\text { The musketeers } \\
\text { worry that } \\
\text { d'Artagnan is } \\
\text { dead until he } \\
\text { stumbles } \\
\text { through the } \\
\text { door. He shows } \\
\text { them the } \\
\text { medallion and } \\
\text { Athos reveals } \\
\text { that Milady was } \\
\text { his ex-wife and } \\
\text { is horrified she } \\
\text { survived the } \\
\text { hanging. } \\
\text { Planchet } \\
\text { discovered that } \\
\text { Anne rescued } \\
\text { Constance from } \\
\text { the prison at } \\
\text { Nantes and hid } \\
\text { her in the same } \\
\text { convent Milady } \\
\text { is headed to. } \\
\text { Spies enter the } \\
\text { scene; a brawl } \\
\text { ensues in which } \\
\text { Planchet is } \\
\text { single-handedly } \\
\text { victorious. The } \\
\text { musketeers and } \\
\text { d'Artagnan } \\
\text { escape. }\end{array}$ & $\begin{array}{l}\text { Medallion } \\
\text { necklace }\end{array}$ & $\begin{array}{l}\text { Knocks/pounds } \\
\text { on the door are } \\
\text { noted in the } \\
\text { script; } \\
\text { Constance may } \\
\text { be revealed } \\
\text { wearing a habit } \\
\text { during the } \\
\text { narration }\end{array}$ \\
\hline $2: 5$ & $\begin{array}{l}\text { Convent in } \\
\text { Bethune, } \\
\text { England }\end{array}$ & $\begin{array}{l}\text { Abbess, Milady, } \\
\text { Constance, } \\
\text { d'Artagnan, } 3 \\
\text { musketeers }\end{array}$ & $\begin{array}{l}\text { Milady tricks } \\
\text { Constance into } \\
\text { revealing her } \\
\text { identity, the two } \\
\text { fight and Milady } \\
\text { poisons } \\
\text { Constance with } \\
\text { the wine as the } \\
\text { musketeers and } \\
\text { d'Artagnan are } \\
\text { heard } \\
\text { approaching. } \\
\text { Milady escapes, } \\
\text { Constance dies } \\
\text { in his arms, and } \\
\text { Athos runs away } \\
\text { to slay Milady. }\end{array}$ & $\begin{array}{l}\text { Tray of food, } \\
\text { wine, chairs, } \\
\text { table }\end{array}$ & \\
\hline
\end{tabular}




\begin{tabular}{|c|c|c|c|c|c|}
\hline 2: 6 & $\begin{array}{l}\text { Golden Lily Inn } \\
\text { on the coast of } \\
\text { France }\end{array}$ & $\begin{array}{l}\text { Innkeeper, } \\
\text { Milady, Athos }\end{array}$ & $\begin{array}{l}\text { Athos and } \\
\text { Milady } \\
\text { encounter each } \\
\text { other, Milady } \\
\text { kisses Athos and } \\
\text { he kills her. }\end{array}$ & & $\begin{array}{l}\text { Script notes } \\
\text { Athos being } \\
\text { revealed by } \\
\text { hiding behind } \\
\text { the open door. }\end{array}$ \\
\hline 2: 7 & $\begin{array}{l}\text { Headquarters of } \\
\text { the King's } \\
\text { musketeers, } \\
\text { France }\end{array}$ & $\begin{array}{l}\text { Treville, } 3 \\
\text { musketeers, } \\
\text { d'Artagnan, } \\
\text { Planchet } \\
\text { (possibly } \\
\text { Buckingham, } \\
\text { Felton, and } \\
\text { Milady in } \\
\text { reenactment } \\
\text { during } \\
\text { narration) }\end{array}$ & $\begin{array}{l}\text { Planchet reveals } \\
\text { that } \\
\text { Buckingham is } \\
\text { dead because a } \\
\text { man named } \\
\text { John Felton } \\
\text { stabbed him in } \\
\text { the name of } \\
\text { love for Milady. } \\
\text { The musketeers } \\
\text { tell d'Artagnan } \\
\text { that Milady is } \\
\text { dead and that } \\
\text { he should tell } \\
\text { Bonacieux of } \\
\text { Constance's } \\
\text { death. Athos } \\
\text { gives him } \\
\text { Milady's written } \\
\text { order from } \\
\text { Richelieu. }\end{array}$ & Note & \\
\hline 2: 8 & $\begin{array}{l}\text { Bonacieux's } \\
\text { house }\end{array}$ & $\begin{array}{l}\text { Bonacieux } \\
\text { (dead), } \\
\text { d'Artagnan, } \\
\text { Rochefort, } \\
\text { Richelieu, } \\
\text { soldiers }\end{array}$ & $\begin{array}{l}\text { We discover } \\
\text { that Rochefort } \\
\text { has stabbed } \\
\text { Bonacieux in the } \\
\text { back. They fight } \\
\text { and d'Artagnan } \\
\text { slays Rochefort, } \\
\text { but Richelieu } \\
\text { and other } \\
\text { soldiers enter. } \\
\text { D'Artagnan } \\
\text { produces the } \\
\text { written order } \\
\text { and isn't } \\
\text { arrested, but } \\
\text { exchanges it for } \\
\text { Richelieu's ring. } \\
\text { Richelieu tries } \\
\text { to offer him a } \\
\text { job, and } \\
\text { d'Artagnan } \\
\text { spares his life. }\end{array}$ & Note, ring & \\
\hline
\end{tabular}




\begin{tabular}{|c|c|c|c|}
\hline $2: 9$ & $\begin{array}{l}\text { Treville's } \\
\text { headquarters }\end{array}$ & $\begin{array}{l}\text { Treville, } \\
\text { Planchet, } \\
\text { d'Artagnan, } 3 \\
\text { musketeers }\end{array}$ & $\begin{array}{l}\text { D'Artagnan } \\
\text { gives Treville } \\
\text { the ring and has } \\
\text { become a } \\
\text { musketeer. The } \\
\text { musketeers } \\
\text { begin to } \\
\text { announce their } \\
\text { retirement until } \\
\text { Planchet tells } \\
\text { them the queen } \\
\text { was kidnapped } \\
\text { into Germany. } \\
\text { They prepare to } \\
\text { embark on } \\
\text { another } \\
\text { adventure; end }\end{array}$ \\
\hline
\end{tabular}

\section{Research}

Collecting visual research is often an integral component of a scenic designer's process. My own research process varies slightly depending on the show I am designing, but generally I will often seek out imagery that falls into two different categories-historical and emotive.

Historical research includes any image that depicts what the architecture, furniture, and décor of the time period actually looked like, and I strive to find information of this kind from museum sources (such as by seeking out museum art collections) if I can to make sure it is a legitimate representation of the time period.

Emotive research includes any image that inspires abstract and/or metaphorical reactions. I will add images to my collection if the content and colors embody a certain mood or invoke an emotional reaction in me that is relevant to the feeling of the story.

My research process for this show mostly took place over the winter break. As I began to search for inspirational material for the overall look of the set as a whole, as well as for each World that the set would embody, I looked for both historical and emotive images. 
For the overall look of the set, I became inspired with the idea of creating a layout that was reminiscent of a playground. The story itself was written for the purpose of entertainment, so I began to envision the world of the play as a playground. I could imagine the actors "playing" on various levels of an irregular set that enabled their movements to be highly active and could inspire the movements of the fight choreography. Figures 1 and 2 are some of the playground images that struck me the most.

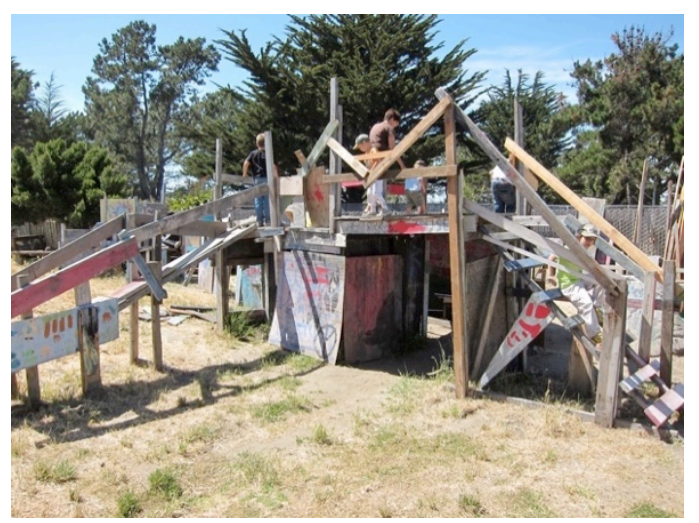

Figure 1: Playground Inspiration

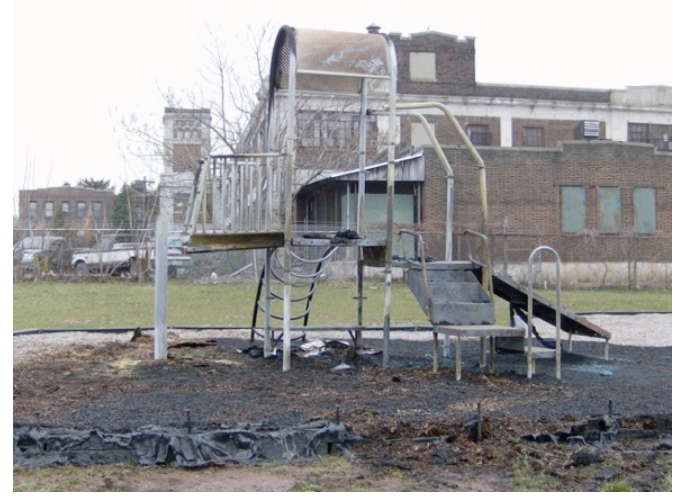

Figure 2: Playground Inspiration

The playground inspiration led me to becoming interested in dollhouses as well. Because of the way that narration and reenactment are laced throughout the script, I could imagine a scenic layout in which multiple events could occur at once in different compartments reminiscent of a dollhouse structure. The endless possibilities in the details of different dollhouses, such as in the ones shown in Figures 3 and 4, also served as a reminder to me to take playful liberties with any architectural elements so that the final design would not feel so heavy for such a "fluffy," shallow show. 


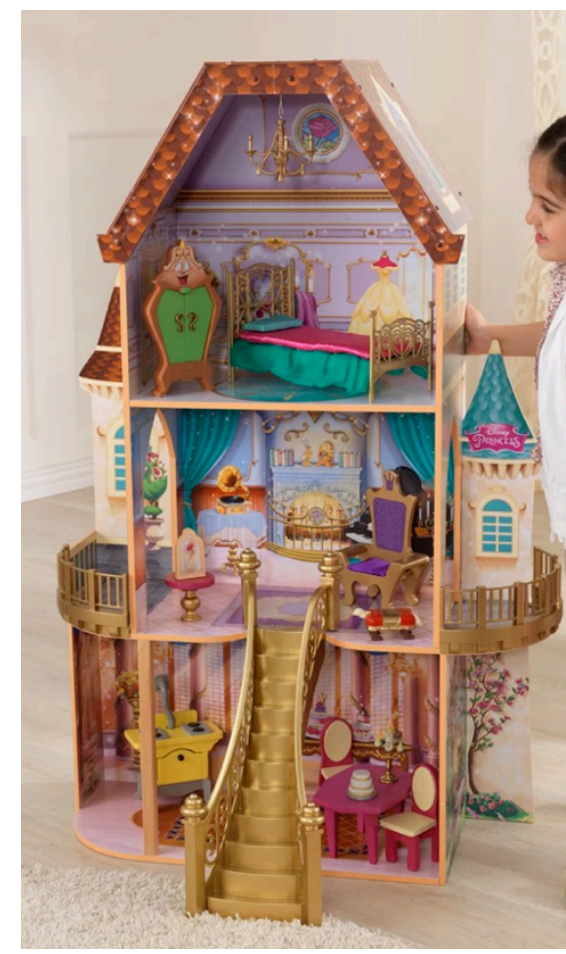

Figure 3: Dollhouse Inspiration

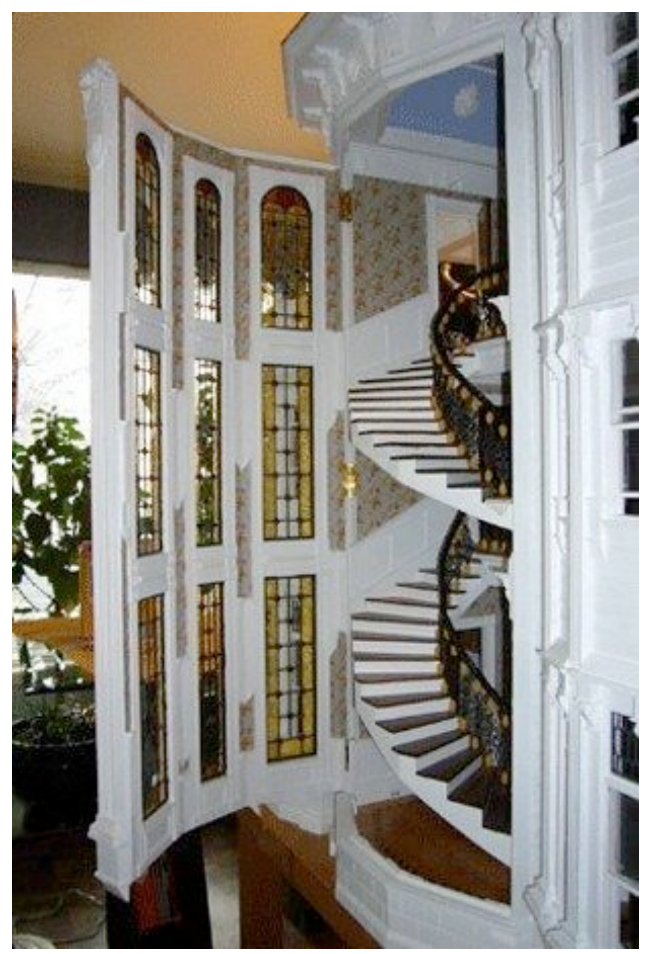

Figure 4: Dollhouse Inspiration

Figures 5 and 6 are photos of Palais Royal in France (the Royal Palace), which I held onto in case any elements of the site's architecture could contribute to the general layout of the set.

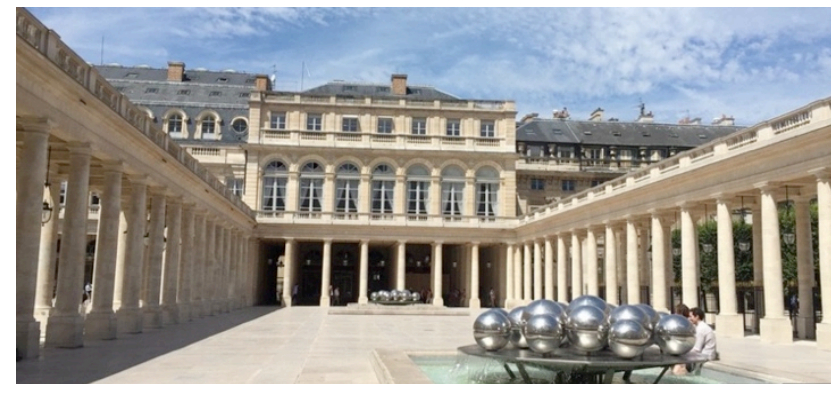

Figure 5: Palais Royal. Paris, France

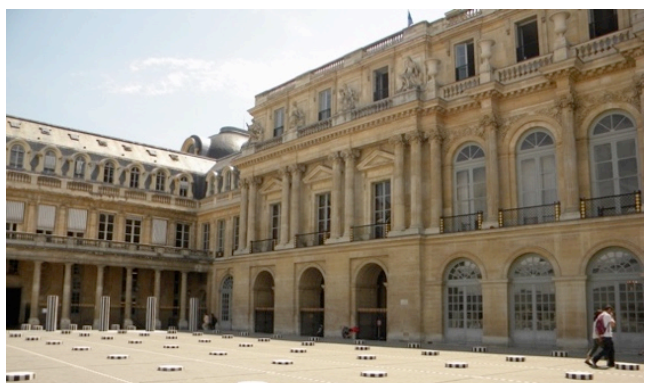

Figure 6: Palais Royal. Paris, France

For the Musketeer's World, my research included multiple playground images and

historical paintings of tavern scenes in muted, earthy color palettes. I was particularly drawn to the figure 7 painting below entitled Brawling Peasants. I had also found a few images of bridges on the Seine River, namely the Pont Neuf bridge and the Pont au Change bridge (Figure 
8), mainly because the action in the story spans from France to England and the musketeers do quite a bit of traveling.

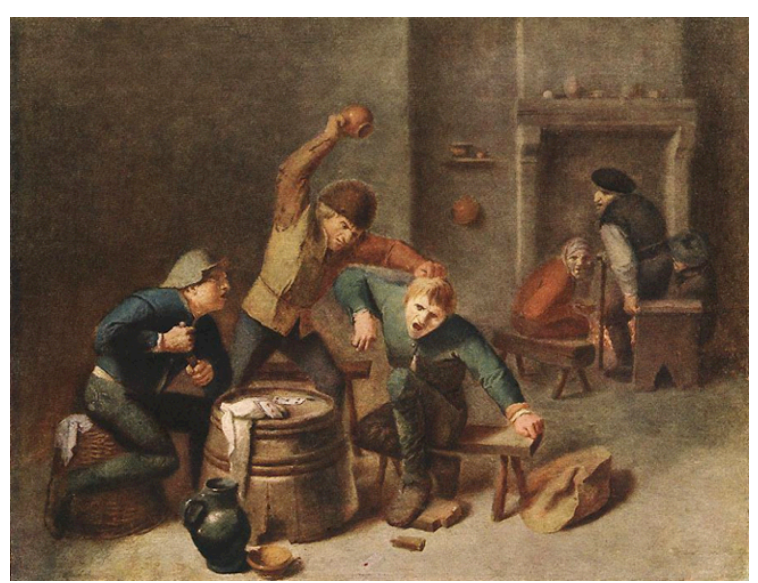

Figure 7: Adriaen Brouwer--Brawling Peasants

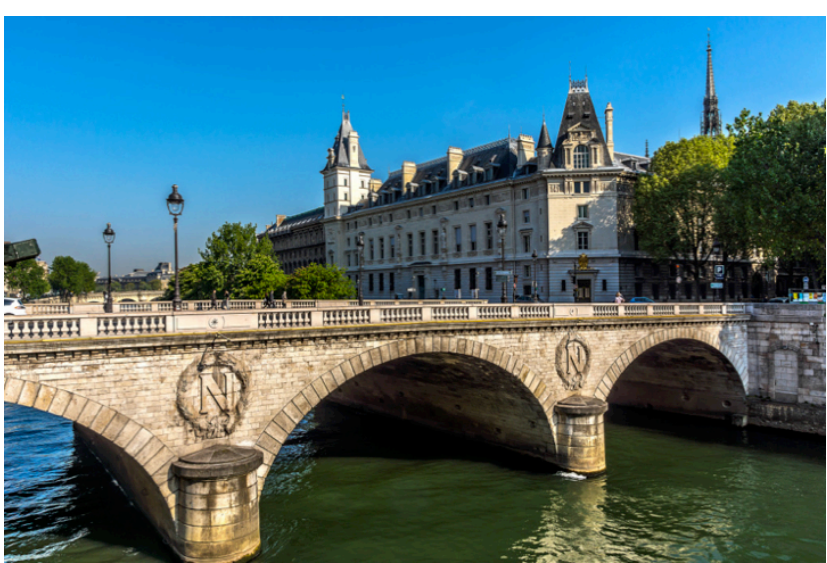

Figure 8: Pont au Change bridge. Paris, France

My research for the King's World mostly consisted of photos of Versailles. Even though I knew that King Louis in the script was technically Louis XIII, and also that the script specifically states that it takes place in 1628 , the Versailles project of Louis XIV was too irresistible to pass up for visual inspiration. I justified this choice because although the stage notes mention the year 1628, there is no part of the actual dialogue in the script that reveals this year to the audience. Additionally, I had already learned that Alexander Dumas took plenty of liberties with historical facts when he wrote the original version, so I figured this was an acceptable research choice. I selected imagery of the organic, gilded gates of Versailles and some photos of the site's interior that oozed with over-the-top opulence and decorative overload. Figures 9 and 10 were among my favorites. 


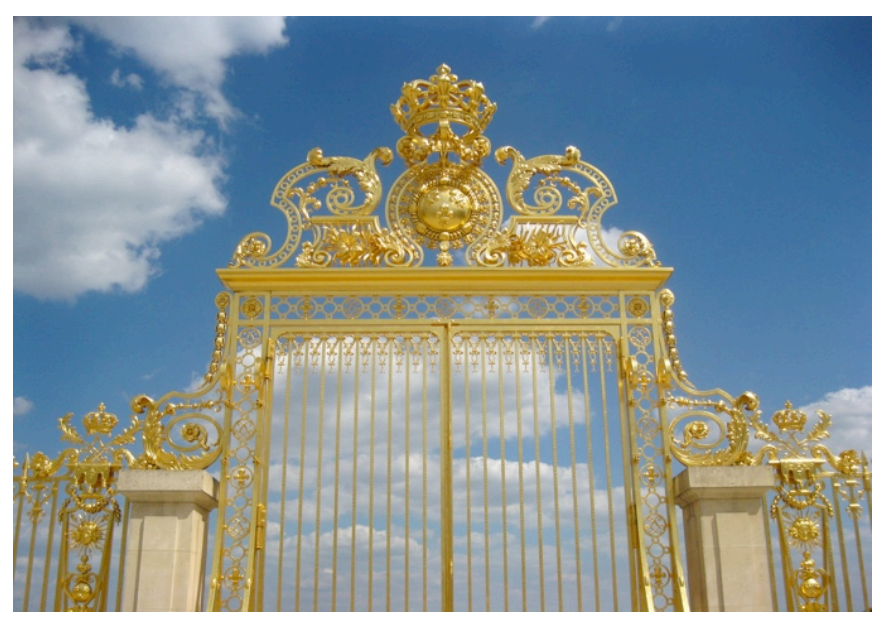

Figure 9: Front Gate of the Palace of Versailles, France

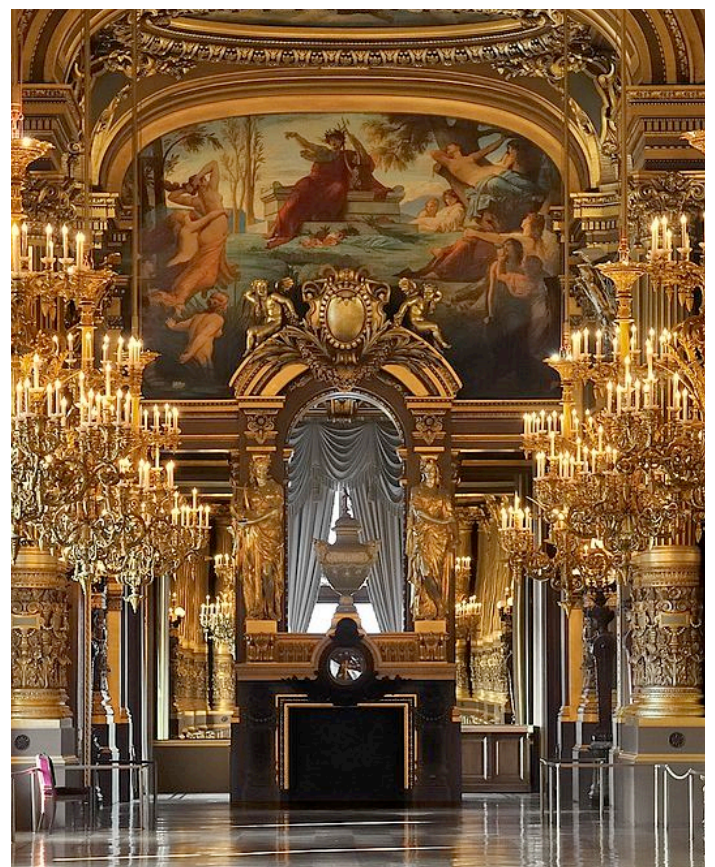

Figure 10: Interior of the Palace of Versailles, France

My research for the Cardinal's World first included photos that simulated glowing embers and blood-red stained glass, because I felt these could be scenic details that very obviously characterized Richelieu as the villain. I was able to find some imagery from the preserved chambers in Palais Royal of the actual historical figure Cardinal Richelieu, whose real name was Cardinal Armand Jean du Plessis. These images are shown below in figures 11-13.

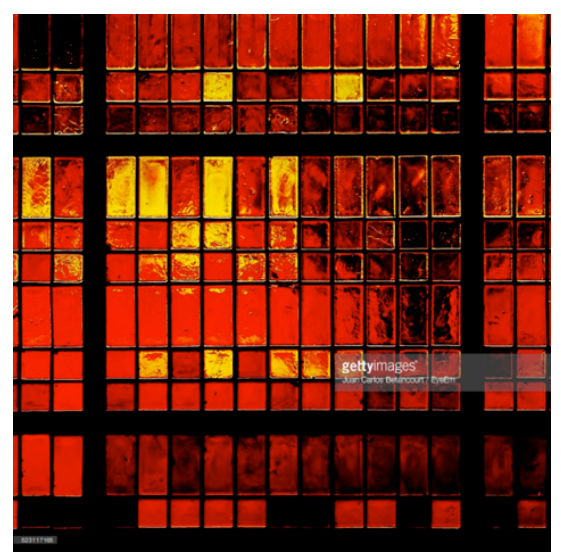

Figure 11: Inspiration for the Cardinal's World

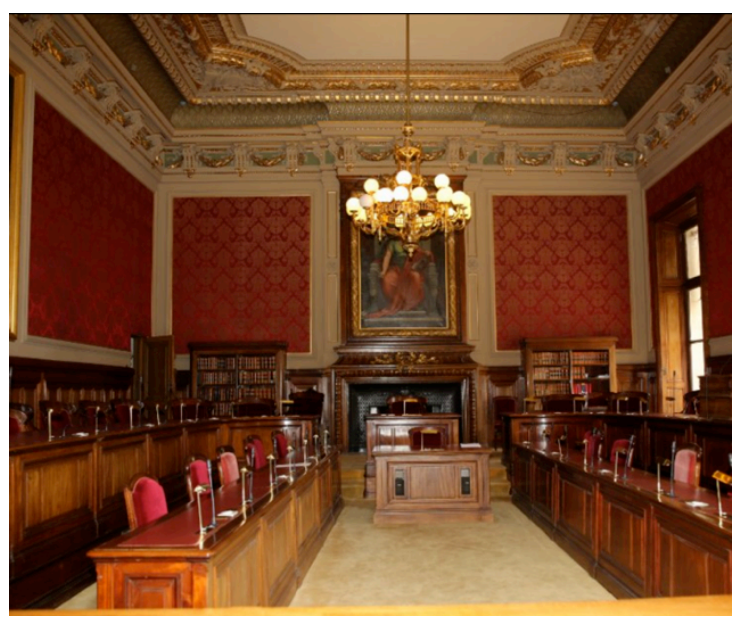

Figure 12: Cardinal Richelieu's chambers, Palais Royal 


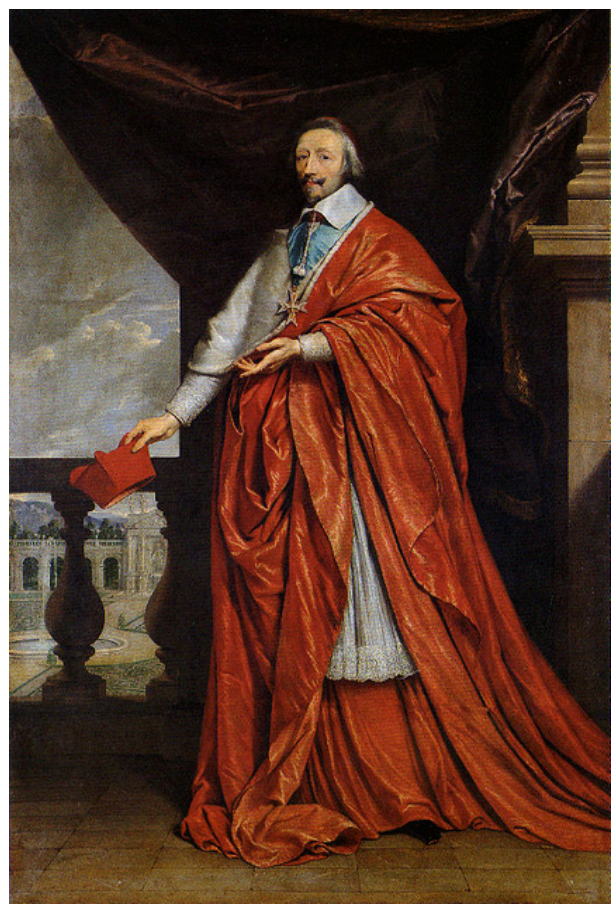

Figure 13: Philippe de Champaigne-Portrait of Armand-Jean du Plessis, Cardinal Richelieu

At the suggestion of my scenic design mentor, Professor Klingelhoefer, I also started researching the work of Hitler's chief architect, Albert Speer. Figure 14 is a photo of the most prominent Third Reich architect.

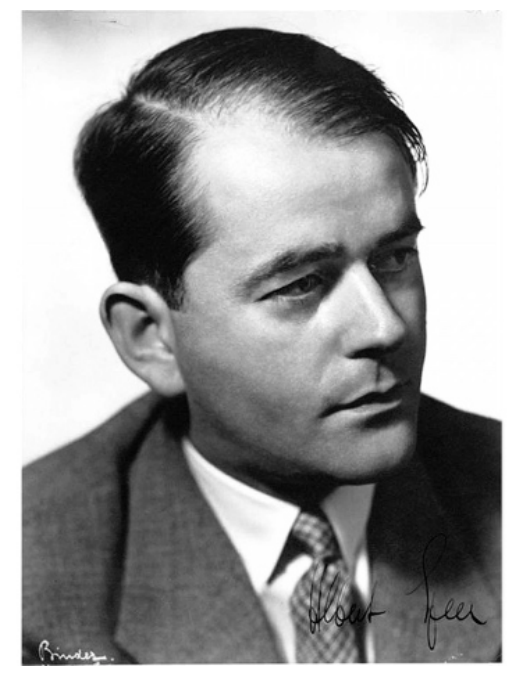

Figure 14: Albert Speer 
The reason for this suggestion was because incorporating fascist-style architecture in the scenery could serve as a contrast between the Musketeers'/Villagers' World (rustic, warm) and the space that the Cardinal and King operated in (sleek, cold). The contrasting architecture would also support the concept of viewing Paris through d'Artagnan's eyes, as Professor Gabara had mentioned in our first meeting. Varying types of architecture could imply new construction and embody the idea that Paris is a city that does not quite know what it wants to be. Many of Speer's projects seemed eerily pristine, "modern", and were designed with an imposing, almost phallic verticality that exuded dominance (Figures 15 and 16), which was suggestive of Cardinal Richelieu's qualities. I was especially drawn to his vertical pavilion topped with a stepped pyramid that he had designed for the Nazi participation in the 1937 Paris World Exhibition.

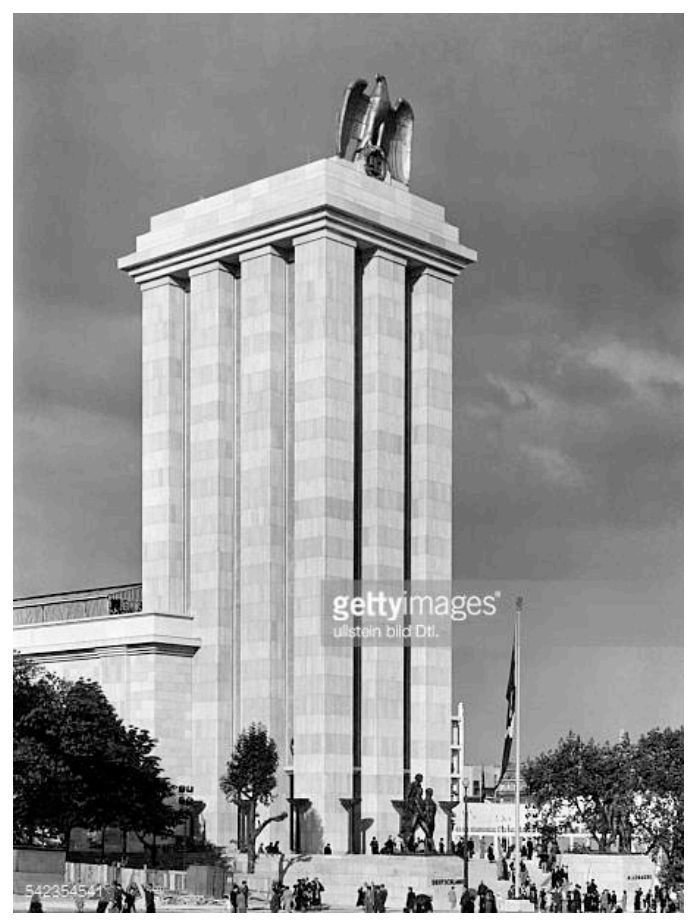

Figure 15: Albert Speer's Nazi Pavilion

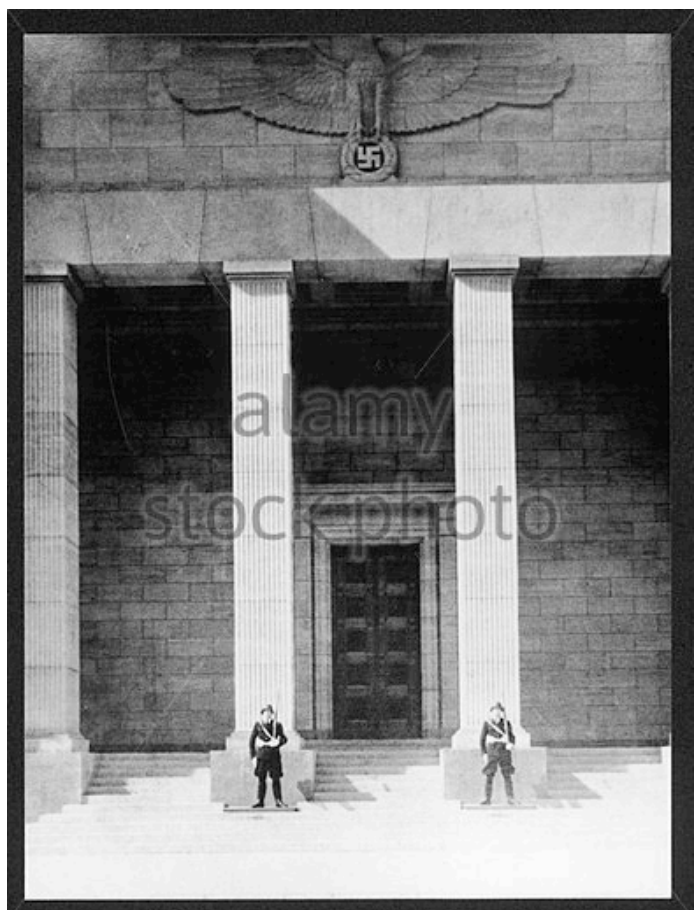

Figure 16: Albert Speer's New German Reich Chancellery 
Once I felt that I had gathered enough material, I created a board with labels designating space for the Musketeers'/Earthlings' World, the King's World, and the Cardinal's World. I also designated a space as an "overflow" area for any additional imagery that I felt could be helpful in creating the overall layout of the set as a whole in an effort to keep all of these colliding worlds in one cohesive container. It is always helpful for me to work with tangible pieces instead of remaining stuck with the digital images on my computer screen, so I print out my photos for the elimination process. For my process on The Three Musketeers, I cut out all of the images I printed and spread them before me. If I felt a certain image would be helpful in the creation of a scenic World, I taped it on my board in its respective place. I did not use permanent adhesive because I wanted to have the constant capability of rearranging the imagery around the board if I wished. In general, sometimes it is helpful for designers to rearrange research images to see them in different combinations alongside other images in order to get ideas flowing. In the end, however, many of the photos I had collected did not make it to my board, even though I had taken the time to print and cut them out. This is because I felt that certain images were either redundant alongside others that I had already chosen, or no longer seemed as relevant or as harmonious alongside others I had chosen.

I then referenced the scene breakdown I had already created to make another chart to go along with this collage. This chart was meant to serve as an even quicker reference to the "Worlds Order" so that I could see how the focus of each world had to shift during transitions. I gave each world an alphabetical letter as a label and made a key of these labels at the top of the chart before showing the order in which they appeared.

Figures 17-22 are images of my completed board and my Worlds Order chart. 


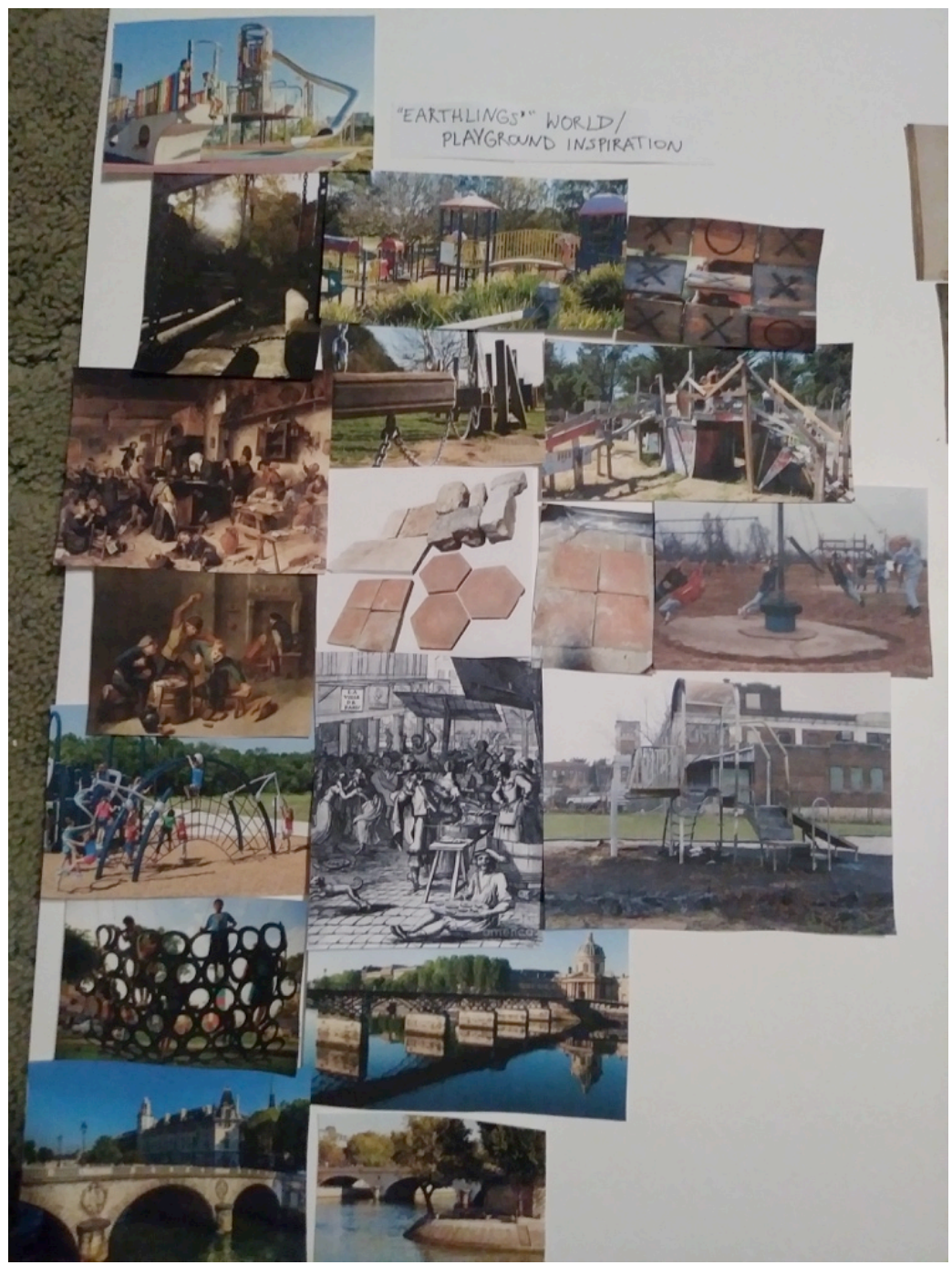

Figure 17: Collage for the Musketeers'/Earthlings' World Inspiration 


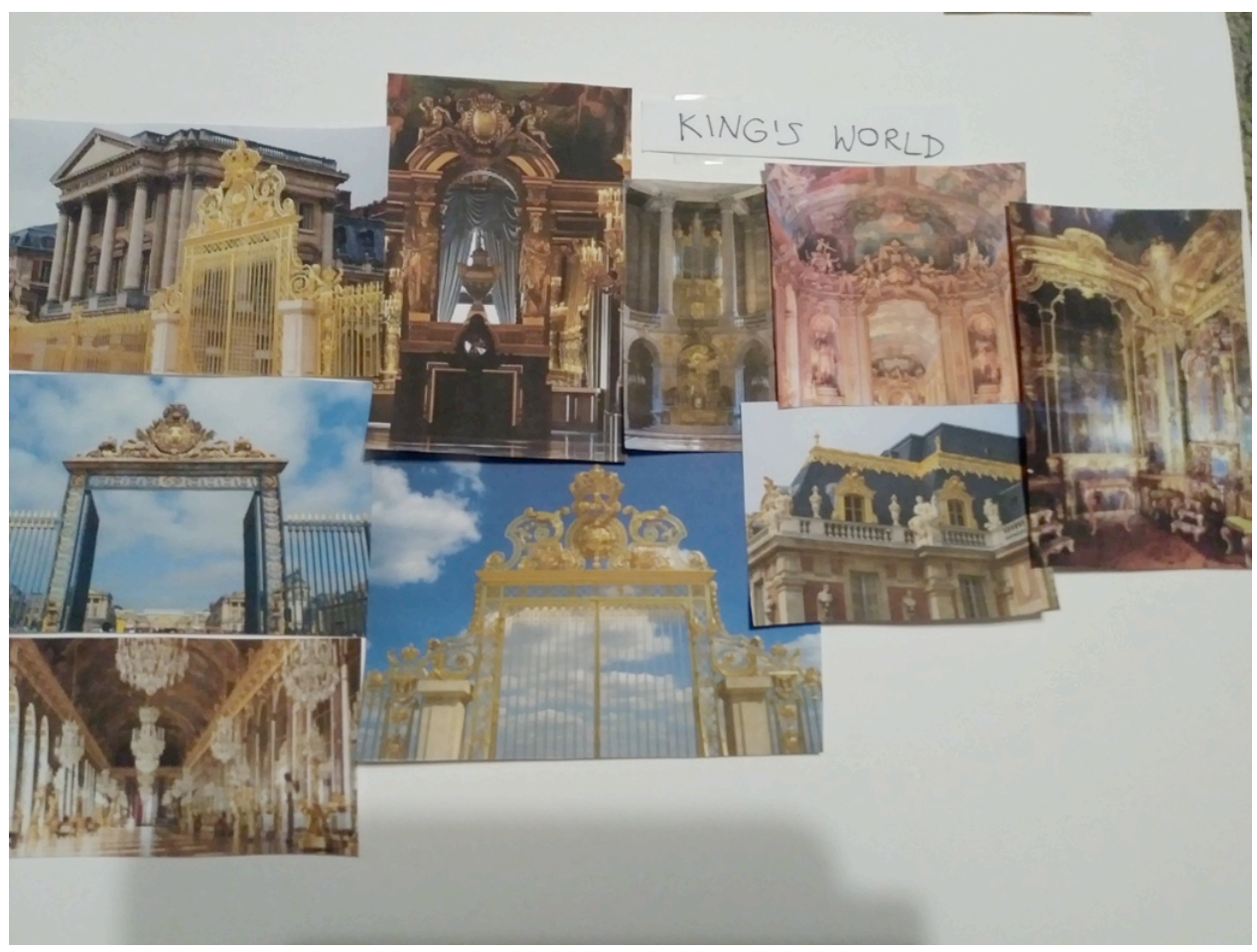

Figure 18: Collage for the King's World Inspiration

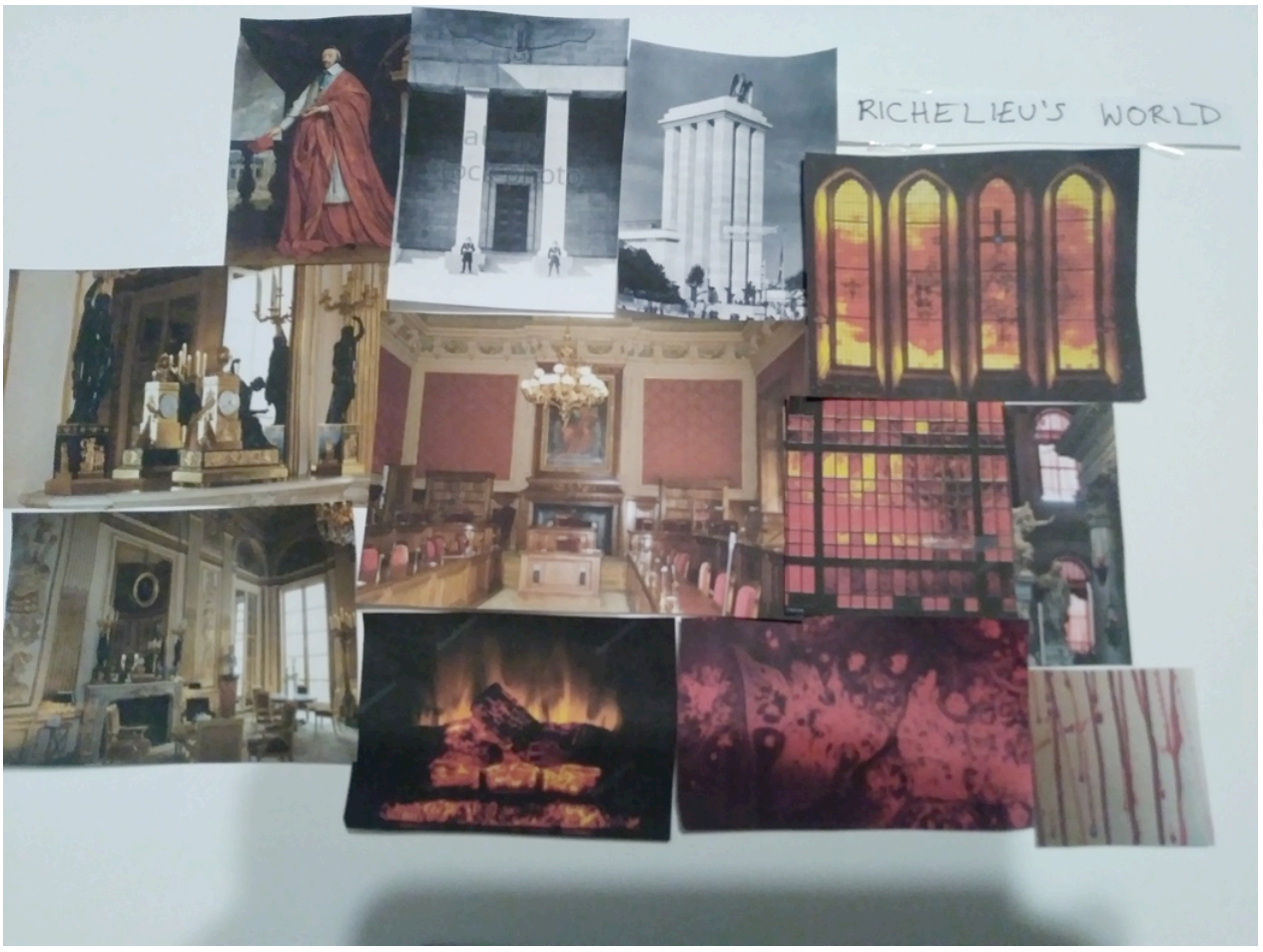

Figure 19: Collage for the Cardinal's World Inspiration 


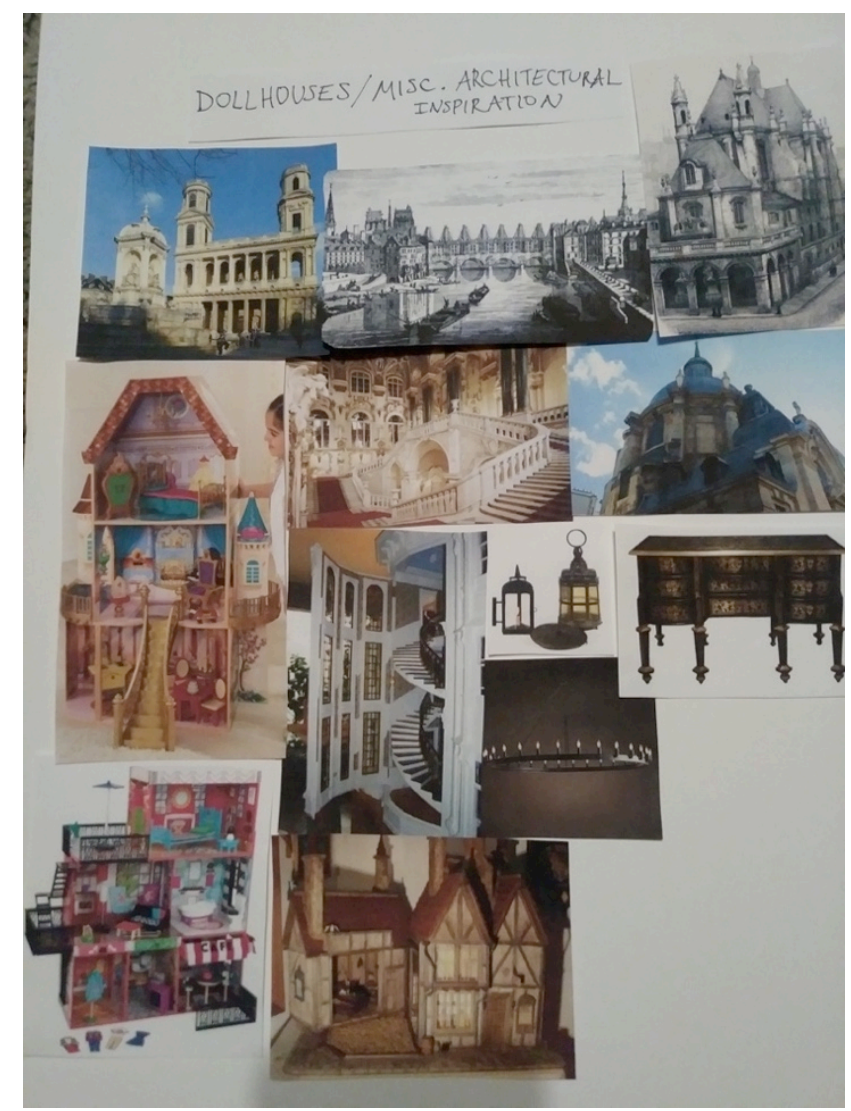

Figure 20: Collage of “Overflow" Inspiration Images

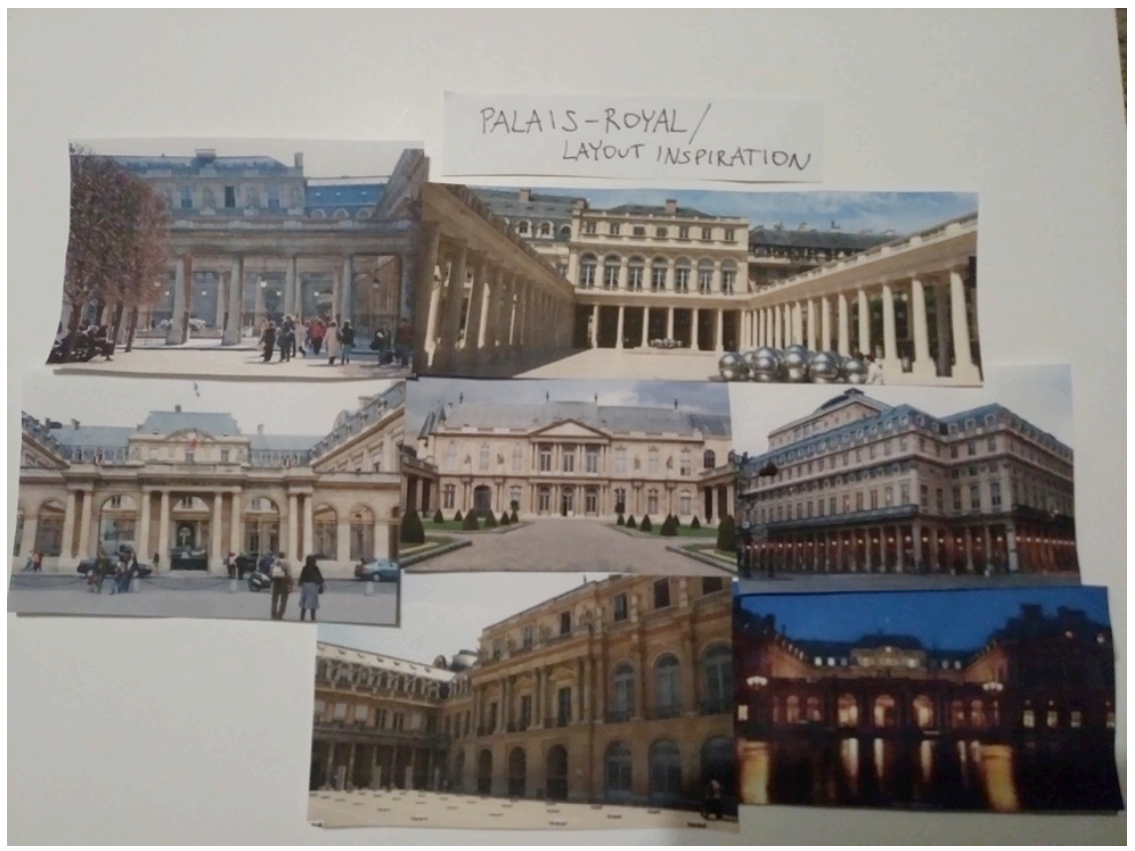

Figure 21: Collage of "Overflow" Inspiration Images 


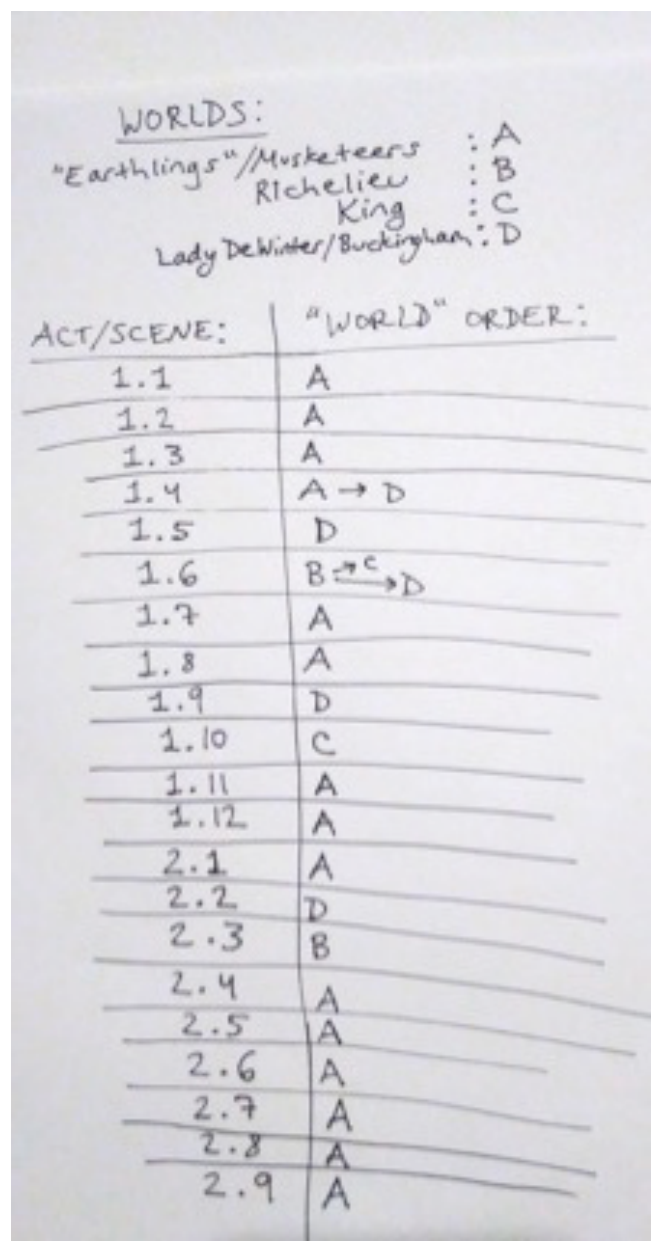

Figure 22: Worlds Order Chart

As mentioned earlier, I completed this step of the process over the winter break, so I took photos of my board and emailed them to Professor Klingelhoefer. He responded that he thought the initial board looked really great, but encouraged me to take the elimination process a step further by reducing the amount of images to four for each World. After some contemplation, I narrowed each group down to the four that I felt were the strongest and that spoke to me the most. I took photos of the updated board and emailed them to him again.

The results are depicted in Figures 23-25. 


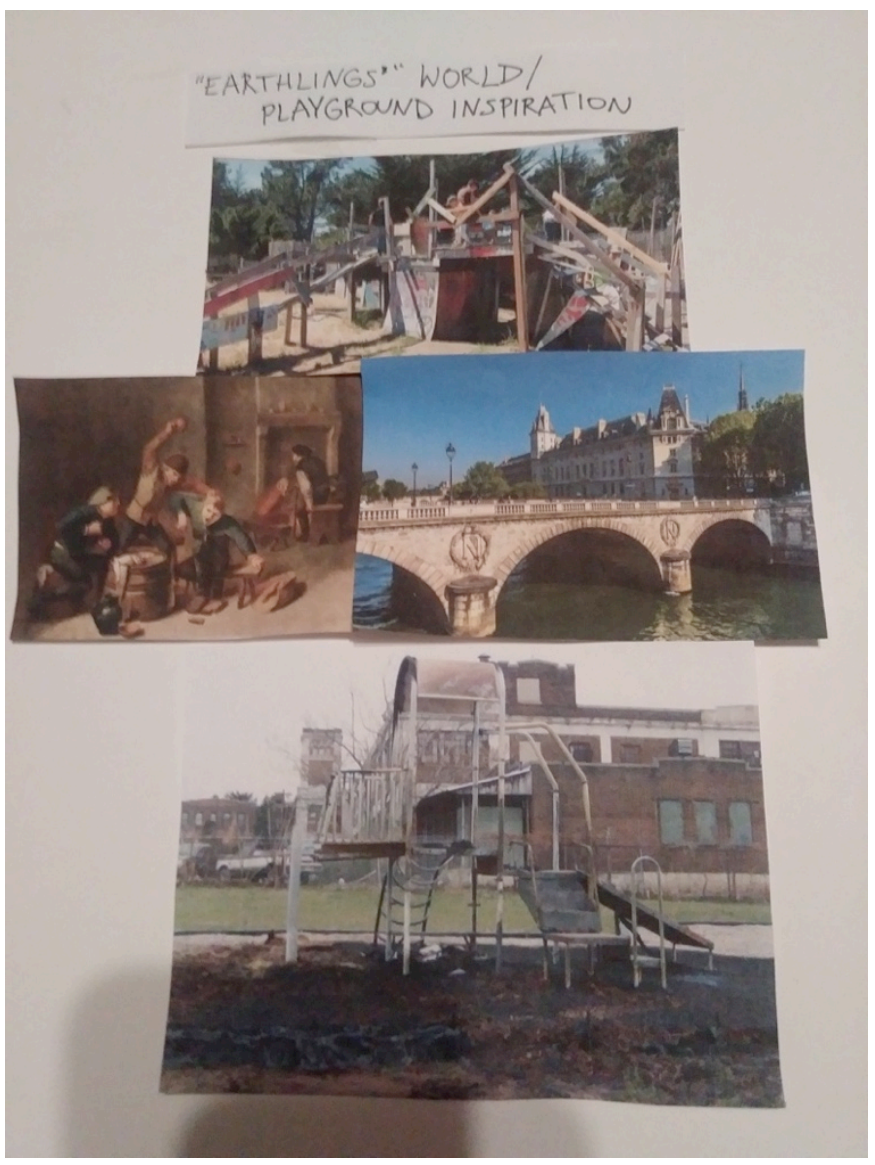

Figure 23: Edited Collage for the Musketeers'/Earthlings' World Inspiration

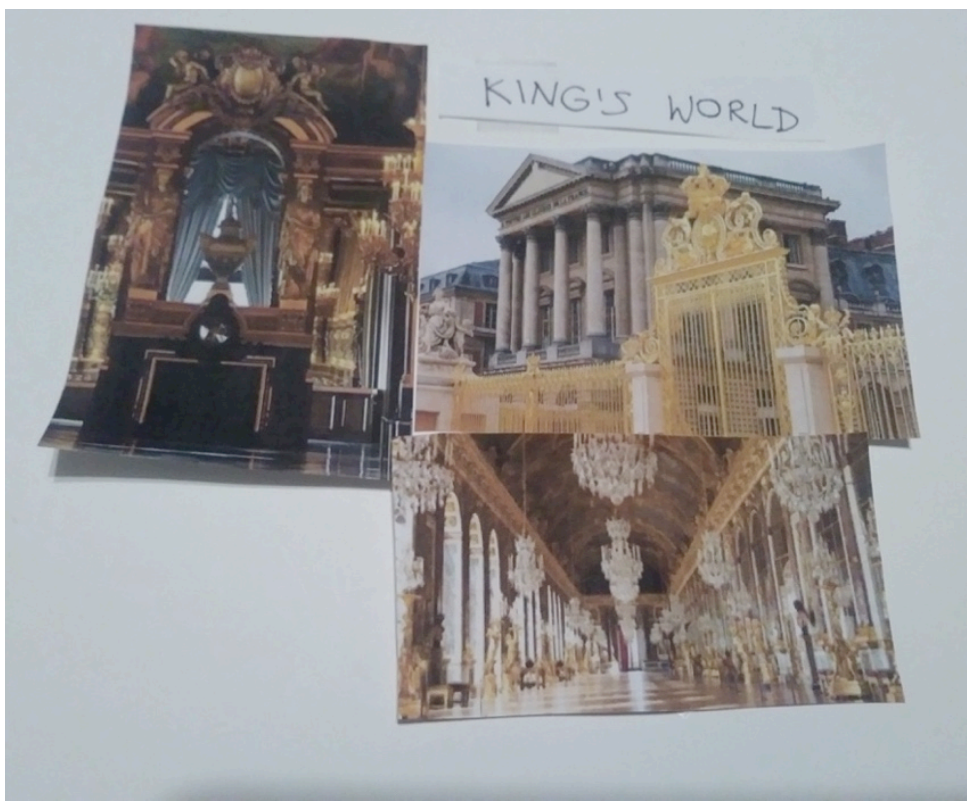

Figure 24: Edited Collage for the King's World Inspiration 


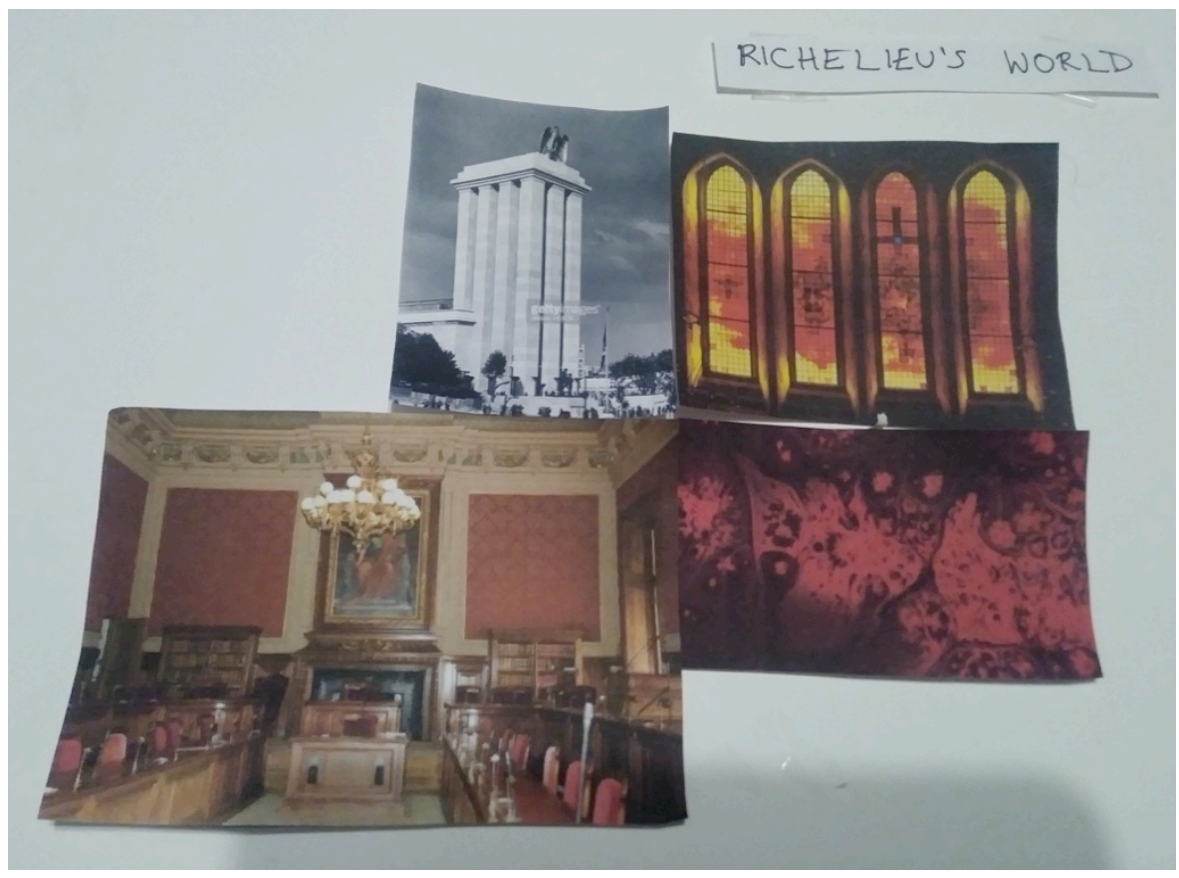

Figure 25: Edited Collage for the Cardinal's World Inspiration

I was most drawn to the images of playgrounds that seemed very dirty and looked to be more "makeshift," as opposed to commercial, and I held on to an image of a tavern brawl scene. These pictures seemed to capture the energy of d'Artagnan and the musketeers.

For the King's World, I kept the frilliest of decorative images. I especially liked the photo of the front gilded gate of Versailles contrasting with the heavy, stone material of the palace itself; it made me think of the King and Cardinal working in the same space. The dainty golden gate looked so light and almost naïve against the solid, looming imposition of the palace material, echoing the King's oblivion to the Cardinal working against him.

\section{$\underline{\text { Rough Design Sketches }}$}

After thoroughly immersing myself in a lengthy research process, it was time to start attempting to put my findings to use. Personally, this is the part in the timeline of my process that I usually dread and often refer to as my "Stumble Period." I always enjoy searching for 
exciting imagery for any show, but it often takes me a while to figure out exactly how to get my findings to work together in a cohesive direction. This time was no different. I was intrigued by all of the images I had narrowed my research down to, but still could not seem to figure out a tangible plan. I remember feeling unsure as to how far or abstracted I should push the playground concept, and I felt like my brain just kept going around in circles.

After letting my edited collage marinate in my brain for a few days, I decided to finally start roughly combining some of its elements in Photoshop to see if something would click. In one of our early meetings before the break, Professor Gabara had drawn a very rough sketch depicting a possible layout for the set that he had in mind. Since I was feeling stuck, I decided to directly combine the structure of his sketch with elements from my own research to see if that direction could work, and if not, at least I knew that I had tried and could rule it out. The rough Photoshop sketches of my first attempt at the design are displayed in Figures 26 and 27. 


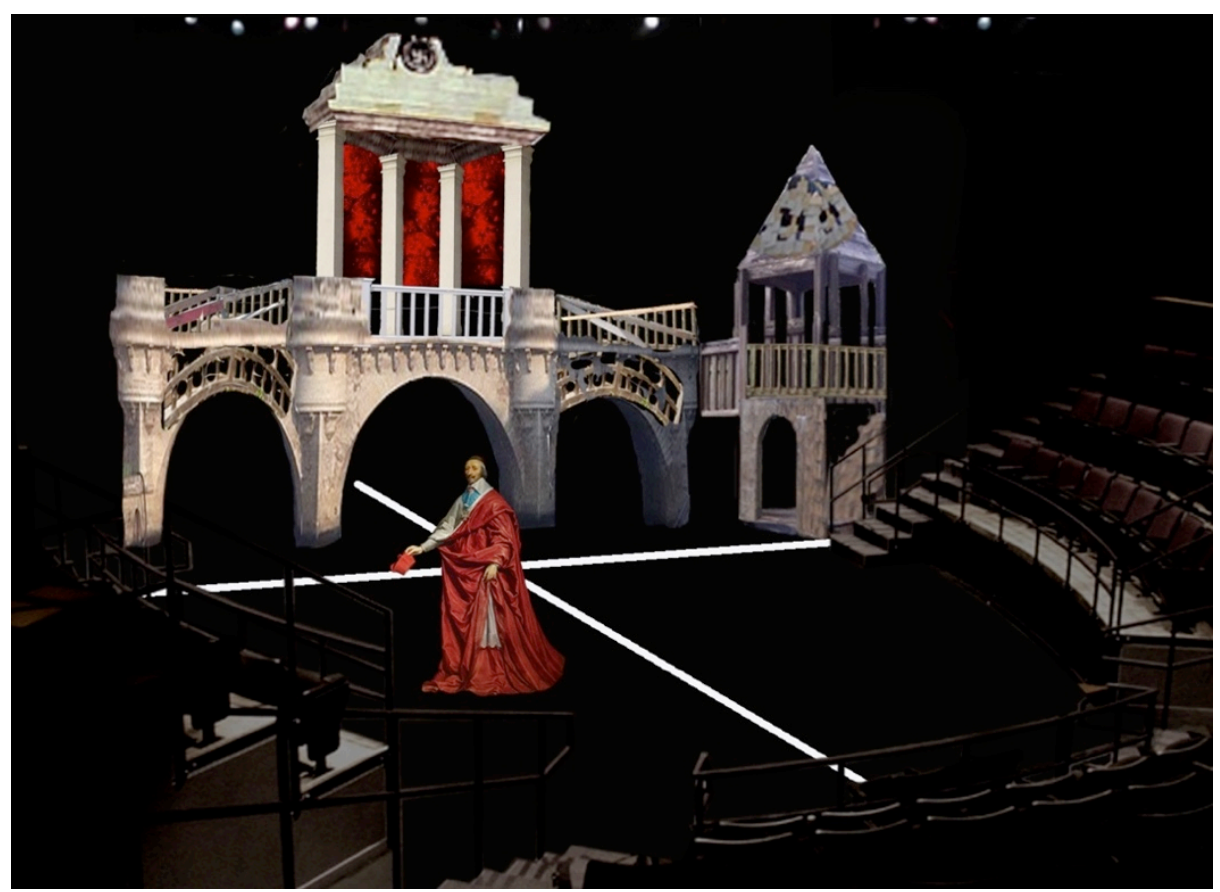

Figure 26: Rough Photoshop Sketch for the Cardinal's World

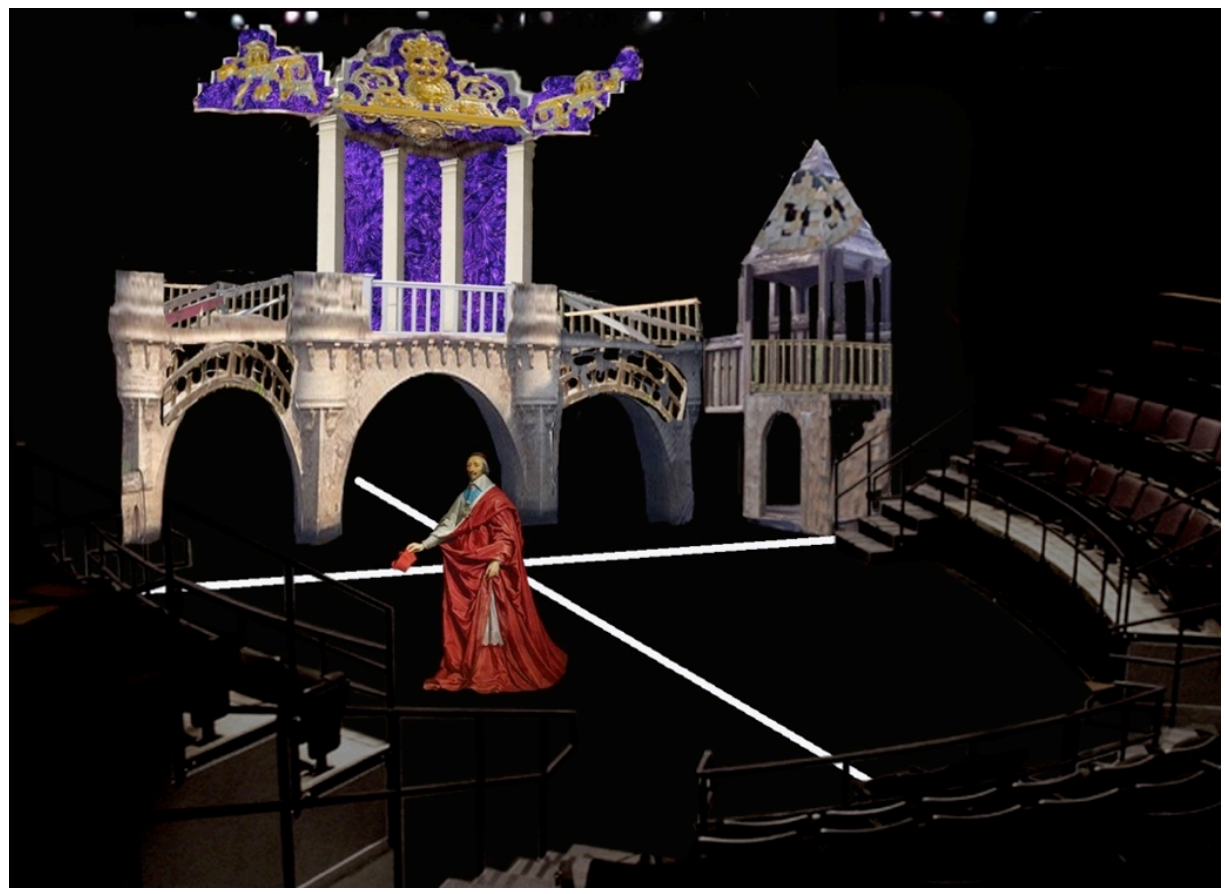

Figure 27: Rough Photoshop Sketch for the King's World 
I utilized my imagery of the bridges over the Seine river in France as the horizontal component in his sketch, and plugged in Albert Speer's vertical structure to achieve the imposing sense of divinity for the Cardinal's/King's World. I had learned in my research that the stepped pyramid is a common motif in fascist architecture, so I decided the stepped pyramid at the top of the tower could indicate Richelieu's space. Panels of rear projection screen, or some sort of plastic that could take lighting effects, could possibly be lit red to indicate the Cardinal's chambers.

I had a fleeting idea of utilizing my dollhouse research in order to change the space to imply the King's World: the stepped pyramid could possibly hinge open, much like a dollhouse, to reveal cheesy decorative detail inside while still keeping the playful spirit alive that I was aiming for. The material that would glow red for Richelieu could possibly glow purple for King Louis.

I had also added a little castle structure on the stage left side, inspired by wooden playgrounds, to give more possibilities for storytelling and acting space. The haphazard wooden beams above the arches were an attempt to incorporate the feeling of contrasting materials and promote the feeling that Paris was under construction.

At this point, winter break was drawing to a close and I was getting ready to head back to school for the spring semester. I was not particularly thrilled about this first version of the design but still had not figured out how else to move forward, so I emailed these sketches to Professor Klingelhoefer for some advice and feedback. He responded that he thought the sketches looked good, but asked my reason for not focusing on a look for the Musketeers' World. He said that when I arrived at school, we should take a closer look at my research 
imagery and try to combine them in different ways, but also to show Professor Gabara these initial sketches to get him onboard.

When I arrived back at school, I explained that I had not been able to design the Musketeers' World because I honestly felt stuck and was somehow more focused on getting the King's and Cardinal's Worlds to operate together, and I had hoped everything else would fall into place around that. We scheduled a meeting with Professor Gabara that same morning in an effort to keep moving forward. I showed him the sketches, and he responded positively, saying that he could make that layout work with the actors. Interestingly enough, the element of the sketch he was most drawn to was not anything I had actually created myself, but was rather the white perpendicular guidelines that are present in the Photoshop file of the Davis theatre that Professor Klingelhoefer had given me to work with. The guidelines are a layer intended to help scenic designers sketch with the proper perspective since the photograph of the Davis was taken from an angle. Professor Gabara stated that the simple white guidelines looked powerful against the black background and seemed to be a phallic line "raping" the arch opening of the horizontal structure.

In a design meeting shortly after this side meeting, I presented my rough sketches to the other designers just to show them my progress, but I was feeling insecure because I was not thrilled about this current direction and I had a strong feeling that my actual end result was going to be very different. I knew I still had some creative problems to figure out, such as how the transitions would flow, and how the actors would be able to get from one space to another, and I knew that as I tried to figure this out, the current design was malleable enough to completely transform. Both Professor Klingelhoefer and Professor of Lighting Design, Alan 
McEwen, pointed out to me that the distance from the stage floor to the grid in the Davis theater was only eighteen feet, and it would be difficult to achieve the strong sense of verticality that I was hoping for in that space because the height of the lower horizontal level would have to sit at the mid-point distance of the tower, thus diminishing that visual vertical effect. I realized that they were right and remembered a phrase that Professor Klingelhoefer often says that set designers should keep in mind: "renderings can lie." This is because it is so easy to adjust perspective to make different layers fit into a Photoshop sketch, but it can be easy for a designer to get carried away and forget that Photoshop renderings are not to scale.

Following the meeting, I went back to Professor Klingelhoefer's office to come up with a plan to push the design further and hopefully resolve some of its issues. He mentioned to me that he was really drawn to the image of the broken-down, dirty playground structure that he knew I had also decided was significant in my research, since it had remained a part of my edited collage for the Musketeers' World. He suggested that I start over in Photoshop and directly try to utilize that image in a second version for a possible design, but without losing a strong vertical element for the King and Cardinal upstage center in the space. We discussed the possibility of two wagons coming together and moving apart in the space for a "conceal and reveal" effect to support the storytelling.

I was more interested in this direction and finally started feeling inspired again. We also discussed the architectural style of "half-timbering" that was prominent in France during the 1600s. Half-timbering consisted of houses and buildings being assembled by load-bearing timber frames, with the spaces between the timbers being filled with a variety of materials referred to as "infill." Infill could include any combination of plaster, hay, or brick, to name a 
few materials. This building style is exemplified in Figure 28. I had included an image of a halftimbered dollhouse (Figure 29) in the "overflow" area of my research collages and decided to pay more attention to it than I previously had.

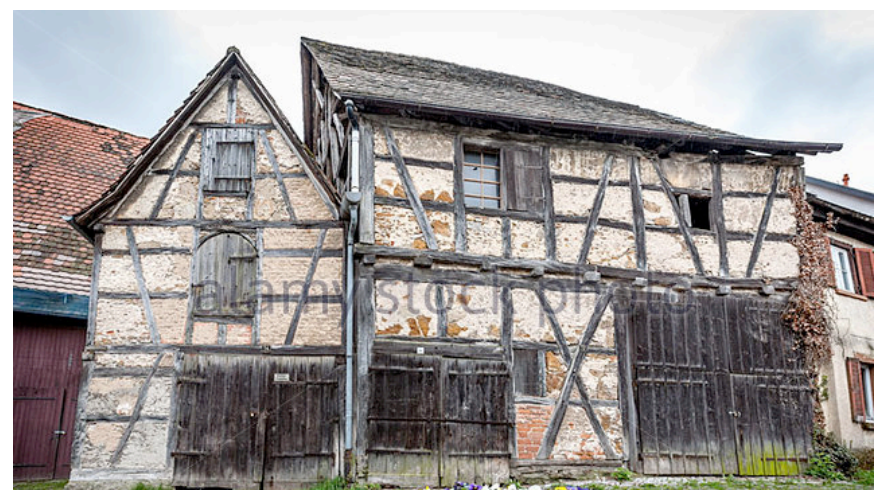

Figure 28: A Half-Timbered House

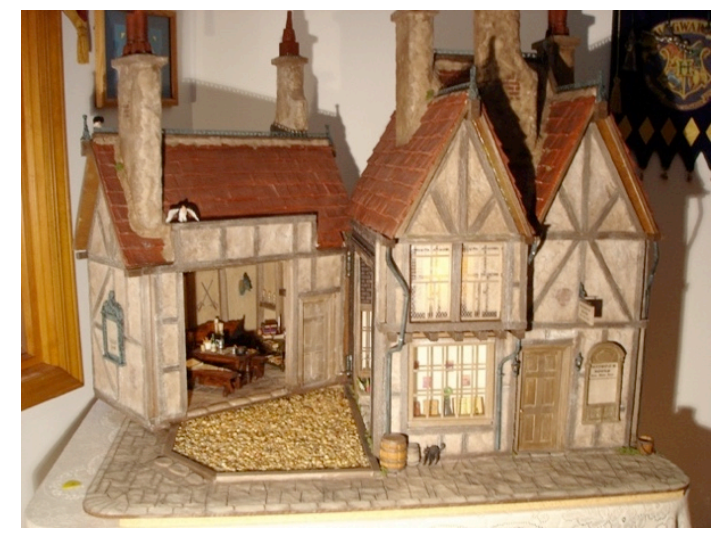

Figure 29: A Half-Timbered Dollhouse

While browsing Pinterest, Professor Klingelhoefer had also stumbled across an image of a handmade model of a half-timbered village, which I learned was for a fantasy role-playing game called Mordheim. This image (Figure 30) was immensely helpful to me because it was reminiscent of both my playground and dollhouse research, but also incorporated historically accurate décor detail. 


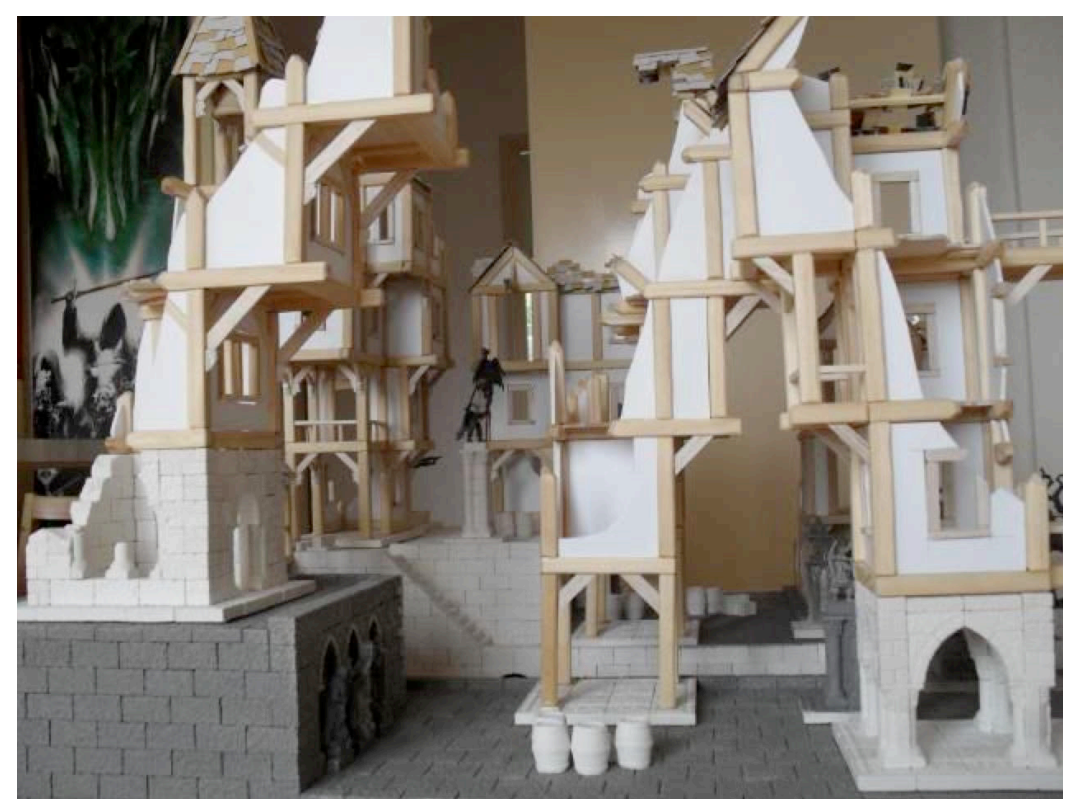

Figure 30: A Model of the Fantasy World of Mordheim

That night, I reopened Photoshop and made another very rough sketch. At this point I did not have the luxury of time to sit down and create a refined rendering, which is a timeconsuming endeavor. The new sketch, shown in Figure 31, was just intended for the purpose of testing out this direction so that I might share the idea with Professor Gabara and the other designers. I roughly combined elements of the dirty playground image with pieces of the halftimbered model and briefly played with the idea of a cross detail in a cobblestone pattern for a possible earthy floor treatment. This attempt at the floor treatment did not end up looking as interesting as I had hoped it would, but I wanted to make sure I kept that aspect of the design in mind as I moved forward since the floor is such a highly visible scenic component in the thrust space of the Gladys G. Davis Theatre. 


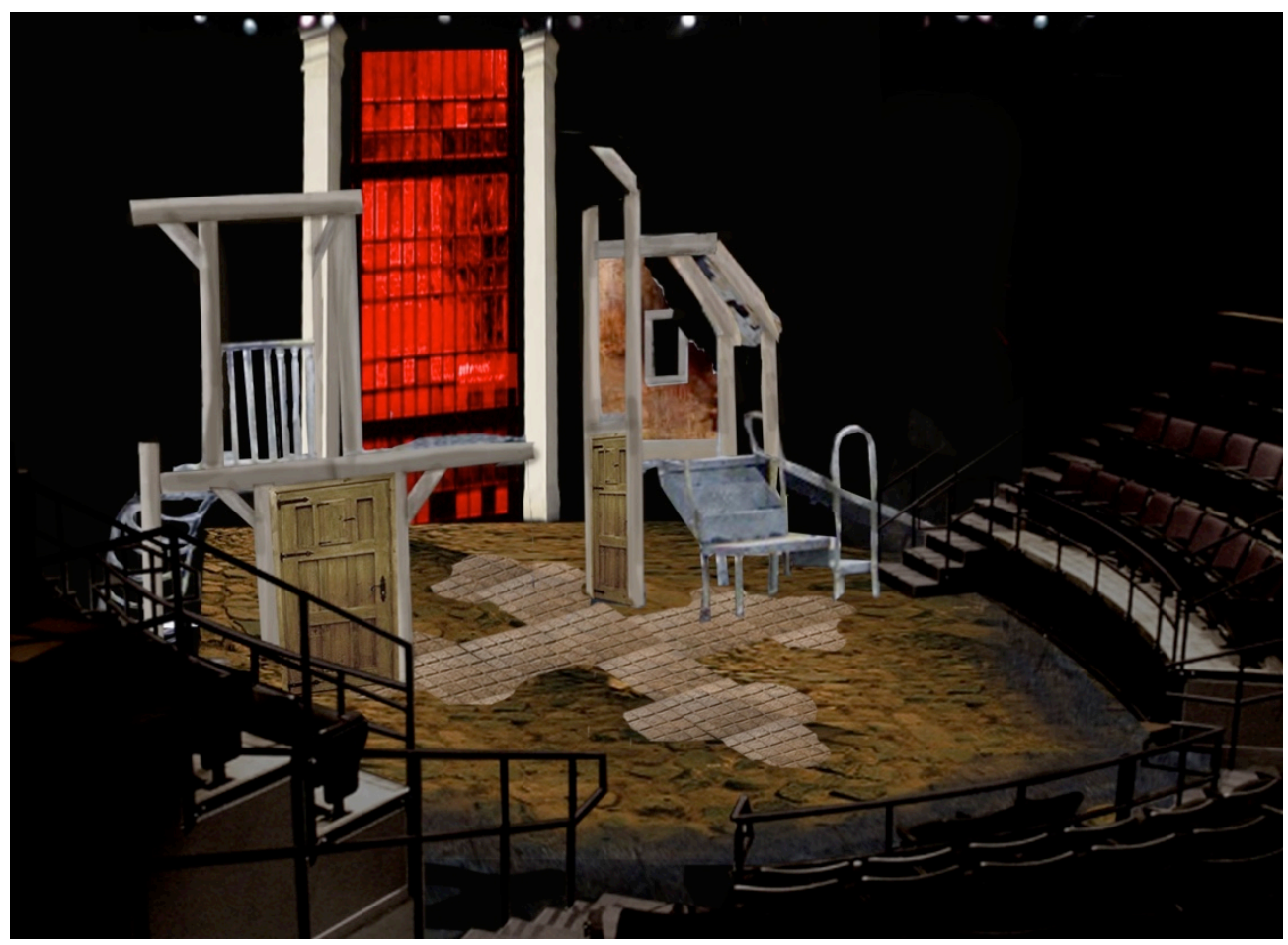

Figure 31: Rough Photoshop Sketch Revision

The next day, I met with the other designers and Professor Gabara to explain the new

sketch. It was important to update Professor Gabara on this change since the first version he had already seen was vastly different, and it was important for the Lighting Designer, Thomas Gillette, to account for two large moveable wagons in his light plot. The reception was positive, and I was excited about refining this new version.

\section{The White Models}

The next move was to take a step out of Photoshop and try to create a rough model so that I could focus more on what the pieces would actually look like and move past the hypothetical concept. That night, I stayed in the Design Room in the Creative Arts Center so that I could refer to our department's half-inch scale model box of the Davis theatre and created rough models for each wagon. At this point, I did not worry about determining the 
actual measurements of the stairs for each wagon, because I knew I could figure that out later while creating a more refined model or while drafting; I just focused on the placement of the stair units and arrangements of different levels on each wagon. I kept the structure loosely held together with tape and pins so that I could rearrange different details if I wished as I kept building (Figure 32). I did not really have a plan as I started this - I kept the process really quick and fun and just referred to my playground and dollhouse research every now and then as inspiration for playful levels on the pieces.

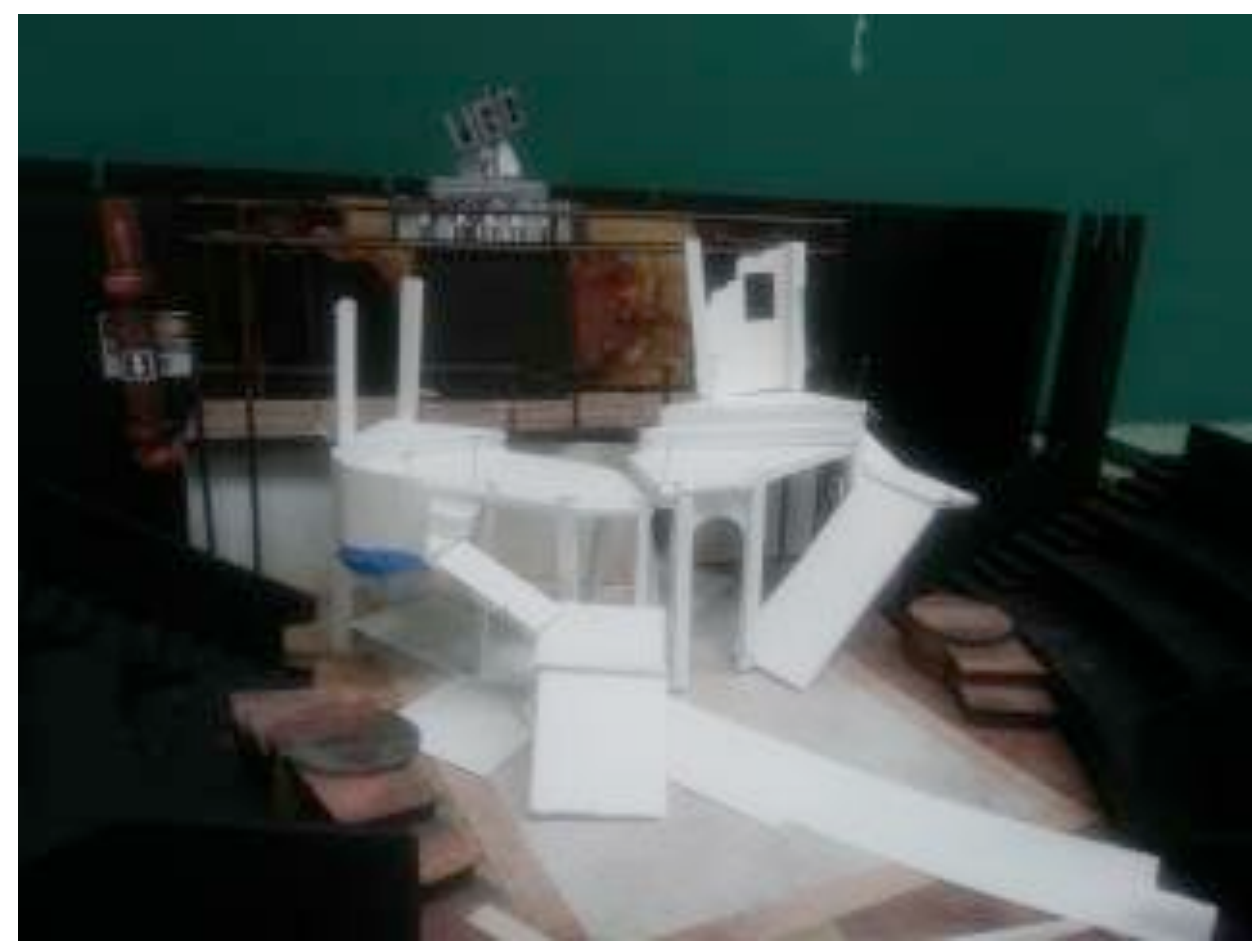

Figure 32: First Rough White Model of the Wagons

The upstage vertical piece was still unresolved, but I kept working on trying to balance that aspect with the wagons. I knew I was still interested in having a stepped pyramid motif, so I created a stepped pyramid base that led up to a narrow vertical unit heavily inspired by Speer. It was comprised of stone pillars revealing slivers of rear projection screen that could 
potentially be lit. I still wanted to keep working on this piece, as it felt a little too heavy in relation to the other pieces, but it was coming along.

I remembered that Professor Gabara was struck by the thin white perspective guidelines in my first rendering, so the last detail I added was some strips of thin white paper on the floor of the Davis theatre model so I could try to play with abstract designs for the floor treatment. These lines started to remind me of roads in a map, and I became intrigued by the notion of making the painted floor treatment look like an abstracted map of Paris, due to the nature of adventure and swift travel in the story.

I showed this model to Professor Klingelhoefer the next day, and he encouraged me that my design was moving in a good direction and to go ahead and make a more refined white model to show Professor Gabara by the end of the week. A white model is basically exactly what it sounds like-it is a model made out of foam core, bristol board, or even just paper, and it enables a designer to quickly execute the shape and size of a structure without having to worry about making final choices regarding color or texture. It usually serves to help designers provide adequate information to communicate an idea to the director and show them how a set piece can look and move in a space.

It took me only two nights to create the refined white model in figure 33 for the wagons, and in this version I also tried my best to nail down the exact dimensions of the stairs so that I would be a step closer to starting to draft. I was finally pleased about the progress I was making with the design overall, and when I looked at my model in the scaled-down Davis theatre box, the space seemed to come alive with exciting possibilities. I began to envision how the actors could use the different levels of the set for their fight choreography, and I also 
started to imagine the possibility of a chandelier hanging in the downstage thrust area of the Davis that would be strong enough for actors to grab and swing from during tavern brawl scenes. I dubbed this idea "the Swinging Chandelier" and made a mental note to pursue this idea seriously. This development inspired me to want to incorporate ropes that the actors could swing on, or even add zip-lines into the set if possible so that the musketeers could dramatically enter a scene in a fashion that was both surprising and fun.

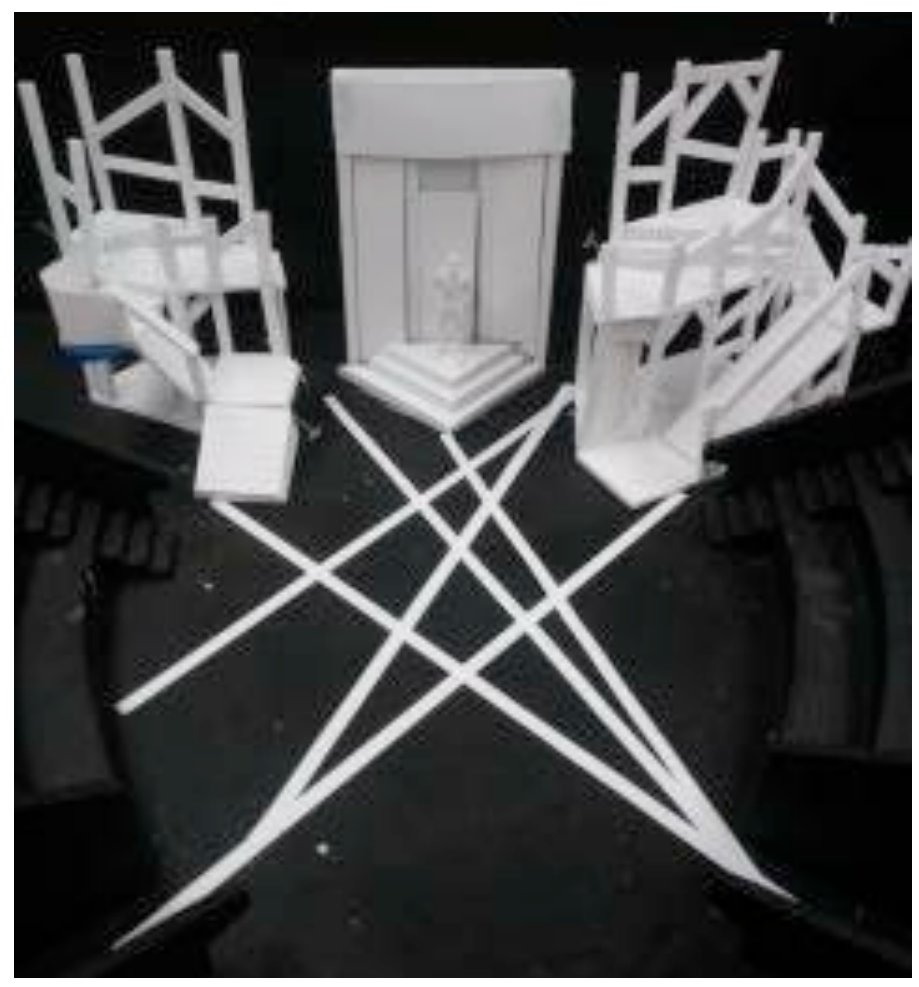

Figure 33: Refined White Model

The next day, I presented the white model to Professor Gabara. I explained that I was still trying to resolve the exact look of the vertical King/Richelieu unit upstage, but that the layout of the set overall would most likely stay the same. He approved the look of the wagon units and was also very receptive to the Swinging Chandelier and zip-line possibilities. He even asked if I could find out if it might be possible for the actors playing the musketeers to zip-line 
over the heads of the audience members and onto the playing space! Having received approval from the director again in this phase of the process, I knew I could keep moving forward. It was exciting that the elements were finally starting to fall into place.

In retrospect, I am still surprised with the amount of progression I had made with the set design in a mere five days. I had gone from spending lots of time feeling completely stuck and a little overwhelmed by my research process to hitting the ground running the second I returned to school from break, and my design had literally gone through four phases of work in that first week of the spring semester.

Overall, I was thrilled with how the latter meeting went with Professor Gabara and was relieved that I could begin drafting the set over the weekend. At this point, I had roughly two weeks left until final designs were due.

\section{The Drafting Process}

The refined white model I had shown to Professor Gabara was helpful for me to start drafting because I was able to directly measure my model with a scale ruler and replicate those dimensions in Vectorworks, a computer program that enables designers and architects to draft in both two-dimensional and three-dimensional space. I spent the majority of the weekend drafting all views of both of the wagon units and was feeling satisfied with the amount of progress I had made in such a short amount of time. However, it did not occur to me in that moment that I had made a major mistake: I had decided to start drafting each wagon beginning with the front elevation (the front view), before going on to draft the plan (top) view and side views. I started this way because I had never drafted a show before that contained so many irregular angles in what I considered very large scale. This caused me to focus on what the 
front of each wagon would look like, and unfortunately it somehow completely slipped my mind that designers should always start with the plan view when drafting a set. The plan view helps us see exactly what a set piece will look like in relation to the space it is in. If we then use that viewpoint to line up our other views as we go on, those other angles may look odd to us on the computer screen because the drawing becomes flattened out in two-dimensional space, but the dimensions of the piece are correct nonetheless. I had somehow thought that even if I started by drafting the front elevation, the other views would inevitably fall into place correctly by using the same process of lining up its elements.

The following Monday morning, I showed Professor Klingelhoefer the progress on my drafts in comparison to the white model pieces, and luckily he noticed right away that something had gone wrong. He pointed out to me that the plan views of the wagons in the drafts looked different than the shapes of the tops of the model pieces I had built. He said if I started over again by reworking the plan views of each piece, there was a good chance I might not need to alter a drastic amount of lines in each of the other views. Since I still had a little less than two weeks left before the design deadline, I still felt confident in that moment that I could complete my design package on time. I also assumed that after this mistake, I would surely draft the pieces correctly the second time around.

I spent the rest of the week updating the drafts I had already started, and found that it ended up being more work than I had anticipated. Since I had completely adjusted each plan view correctly, I found that almost none of my previous lines in the other views lined up properly, so I had to redraw everything I had drafted the previous weekend. Separate homework assignments and other projects started to pile up, such as our school's involvement 
with creating the set for the West Virginia University Children's Hospital Gala, I began to lose focus and did not get as far on the drafting during weeknights as I had hoped; I ended up needing to devote more time to fixing my mistakes over the following weekend so that I could fully focus.

When I arrived at school the next Monday, I only had four days left to complete the drafting package. I was starting to feel stressed because I still had to draft the vertical unit upstage, add all of the dimensions and notes in the sheet layers, and completely update my Photoshop renderings, but I still felt that I could accomplish all of this by the deadline because I had already drafted the most difficult scenic units...or so I thought. I had emailed my updated drafting of the wagons to Professor Klingelhoefer on Sunday evening, and stopped in his office first thing on Monday morning. He apologetically broke the news to me that apparently, all of my various stair units on each of the wagons, including the escape stairs, had too many inconsistencies in their rise and run measurements that neither of us had realized before, and he knew this would cause issues in the build process later on. He assured me that it was better to fix all of these issues sooner rather than later. I instantly became more stressed because both wagons featured two stylized stair units each: a disjointed unit that was meant to be seen by the audience, and a set of curving (out-of-sight) escape stairs. I knew that changing any part of the drafting would inevitably lead to the necessity of making many other adjustments in every view of each unit, or else the drawings would be riddled with problematic discrepancies. Any irregular or complicated issues in the scenic units that were not fixed at this point would only cause more issues in the shop later on. 
It was in that moment that reality sank in and I knew that I would not be able to meet the upcoming design deadline on Friday. Thankfully, the Production Manager rescheduled the presentation for final designs to take place on the following Monday, granting me an entire weekend to finish the design package. Professor Klingelhoefer had also mentioned to me that since the wagon units had so much irregular detail, I should create an additional drafting plate for each wagon that split the plan views with a section line, thus breaking down the detail of the front and back elevations of each piece even further. This would help to provide even more clarity for the Technical Director, Nicholas Skiba, that otherwise would not be as easily communicated in the views I had already drafted.

\section{The Last Pieces: Conceptualizing "The Magic Doors" and "The Hanging Crest"}

It was also during this final week before the postponed design deadline that the look of the upstage unit for Richelieu and the King fell into place. While looking at the Photoshop renderings that I had gradually started updating since the refined white model was built (Figure 34), I still thought the upstage unit looked too heavy behind the wagons. Although I was going for a contrast between the Musketeers' World and the other worlds, the vertical piece seemed too out of place. 


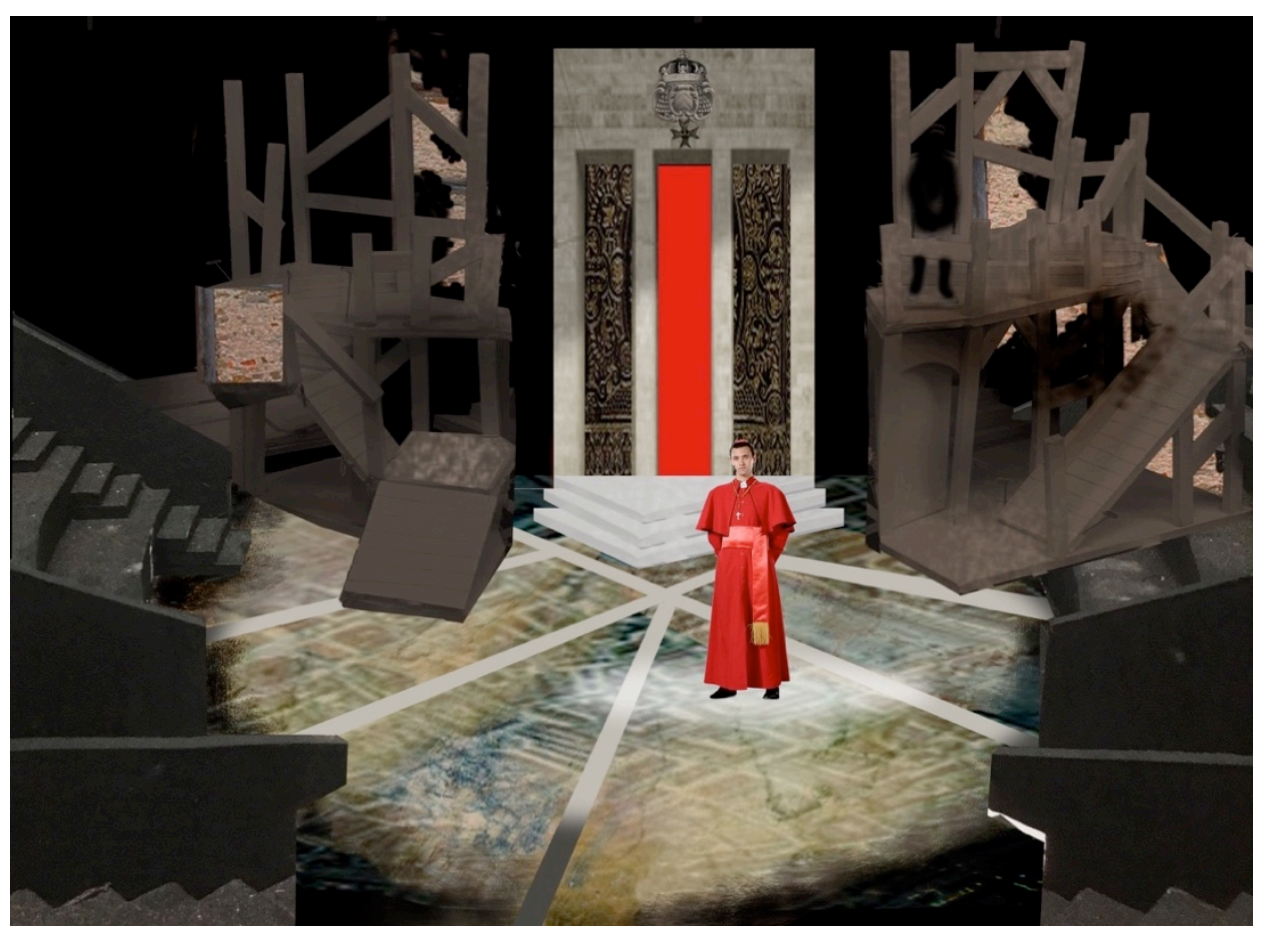

Figure 34: An In-Process Updated Photoshop Rendering of a Possible Cardinal's World

Professor Klingelhoefer suggested that I try to keep some of the elements that I already had there, but to strip the piece down and rearrange it. I knew that I wanted to keep the stepped pyramid base and rear projection screen for lighting effects, and the only other way I could think of showing two worlds on that platform was to eliminate the stone pillars and incorporate spinning doors with a different look on each reversible side. I had previously utilized spinning doors in my last design for Assassins in the Fall semester, so I wanted to try to find a way to differentiate that effect this time around. Professor Klingelhoefer suggested the idea of incorporating hinges onto each reversible door so that an additional panel could be either be hinged shut, or unfolded to reveal a third look. Revealing a third look was a perfect suggestion because I was no longer limited to just having indicators of the Cardinal's World and the King's World: I could also have a "neutral" look for the scenes involving Milady de Winter 
and Lord Buckingham, supporting the Professor Gabara's earlier analogy of those characters being "in the same hotel, but in different rooms" as the Cardinal and King. I decided that one side of the spinning doors would be the "Neutral Look" and feature a glossy, dark wood grain treatment with curved molding so that they would look like doors that could conceivably be found in any 1600s European upper-class establishment.

The reverse side of the spinning doors would feature the Cardinal's Look, and I was inspired by heavy bank vault doors to retain the essence of imposition and power. Opening and unfolding the extra hinged panels on each door presented the possibility of there being four panels in total instead of two and I realized that this reveal could be utilized as a "magical" moment of surprise in the transitions. That being said, I decided to use this third look for the King's World, namely for the grand ball scene, since that moment only happens once in the show. The four doors would be base-painted purple and decorated with gilded detail and an over-the-top Sun King image, characteristic of Louis the XIV.

I had decided early on that I wanted there to be some sort of symbol associated with the upstage unit to represent the combined and conflicting power of the King and the Cardinal, and I found in my research that there were often crests created throughout French history to commemorate the pairings of monarchy and clergy in power. These crests, such as in Figures 35 and 36, often combined the symbol of a king's crown with a cardinal's double-armed cross, so I combined this imagery to create my own stylized crest (Figure 37) to hang above the Magic Doors. 


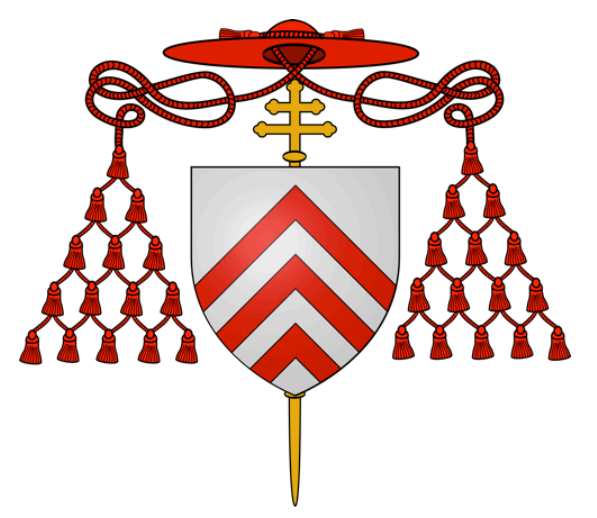

Figure 35: Cardinal Richelieu's Coat of Arms

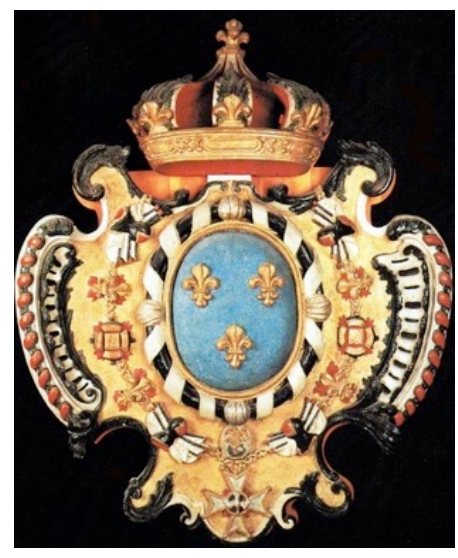

Figure 36: Coat of Arms for King Louis XIII and Cardinal Richelieu

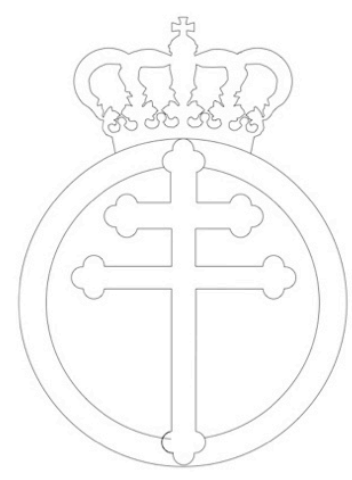

Figure 37: A Rough Vectorworks Sketch of My Own Design for the Hanging Crest

The rear projection screen would hang behind the Magic Doors, on the upstage edge of the stepped pyramid platform, with a wall in front of it bearing simple trim to make the screen look like part of a basic interior wall. I had already assumed that we would recycle a rear projection screen from a previous production for the sake of budget, and I knew that the dimensions of the screen were $13^{\prime} \times 13^{\prime}$. Because the floor-to-grid measurement in the Davis theater is eighteen feet, and the stepped pyramid was designed at a height of two feet, I knew there would be a three-foot gap between the top of the pyramid base and the bottom edge of the screen. I designed this interior wall at five feet tall, so that it would conceal this gap and also provide the potential of a masked crossover for the actors. 
I spent the rest of that week finishing the drafting package, which also resulted in me staying up until the sun came up on Sunday morning, only stopping to nap for a few hours before starting again. While I am accustomed to having to pull all-nighters from time to time for a project, I was pleasantly surprised that this one in particular was not stressful, but actually rather enjoyable, and I was feeling confident about the way the drafts were coming along. I completely finished the package at 2:00 AM on Monday and drove to the Creative Arts Center immediately to print them out on the plotter because I was too worried I might have printing issues if I had waited until the school day started. Figures 38-48 are images of my drafting plates.

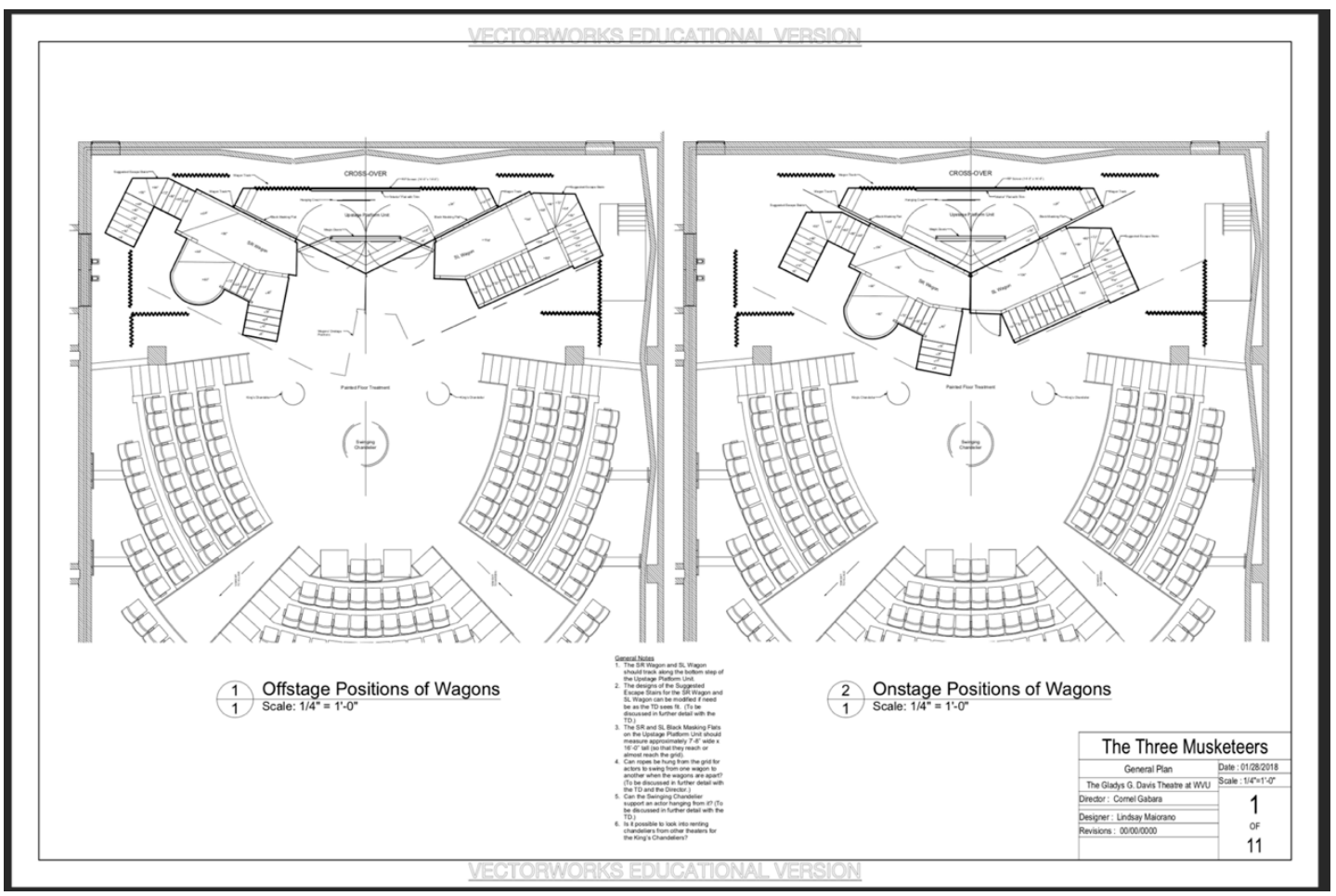

Figure 38: Drafting Plate 1 


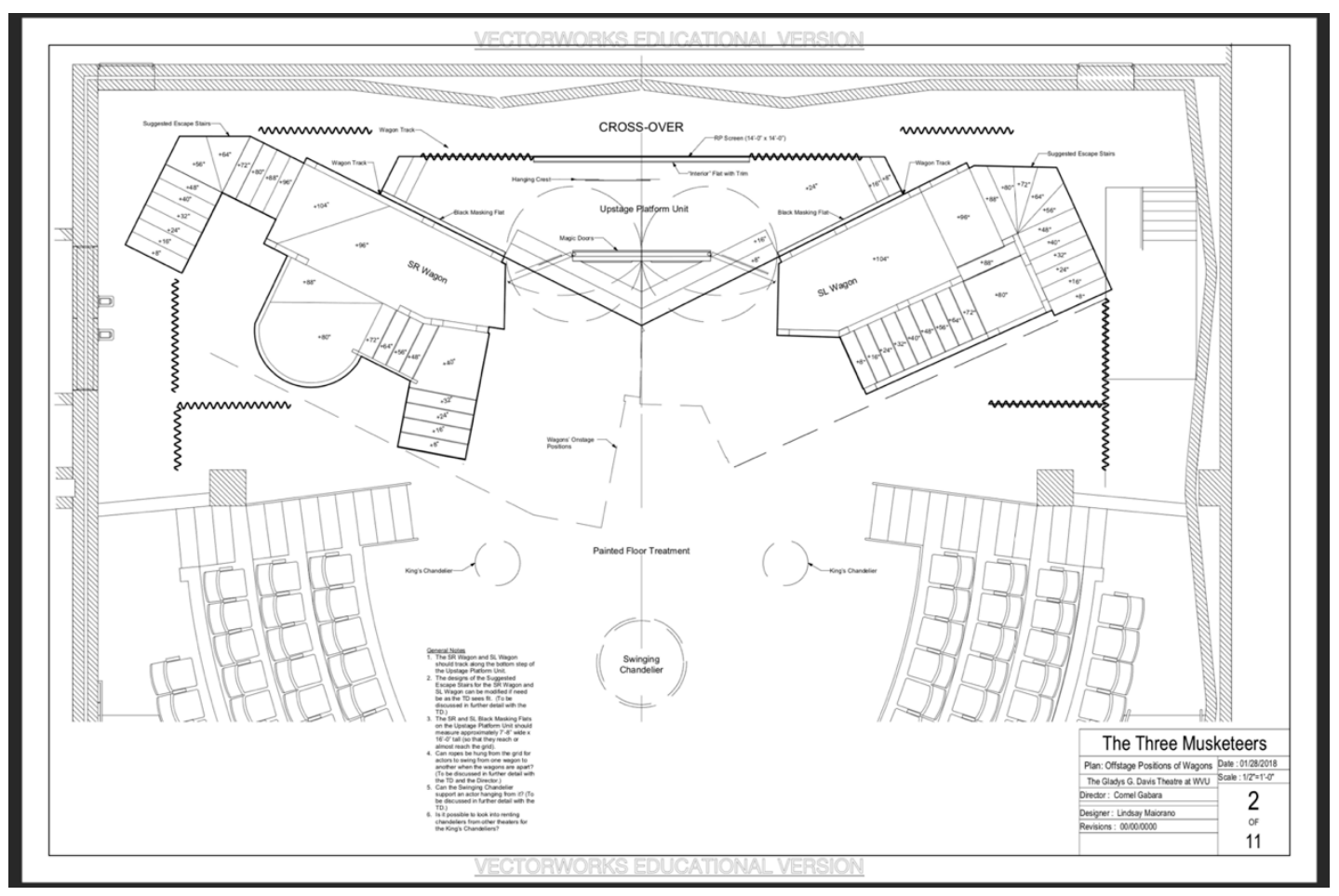

Figure 39: Drafting Plate 2

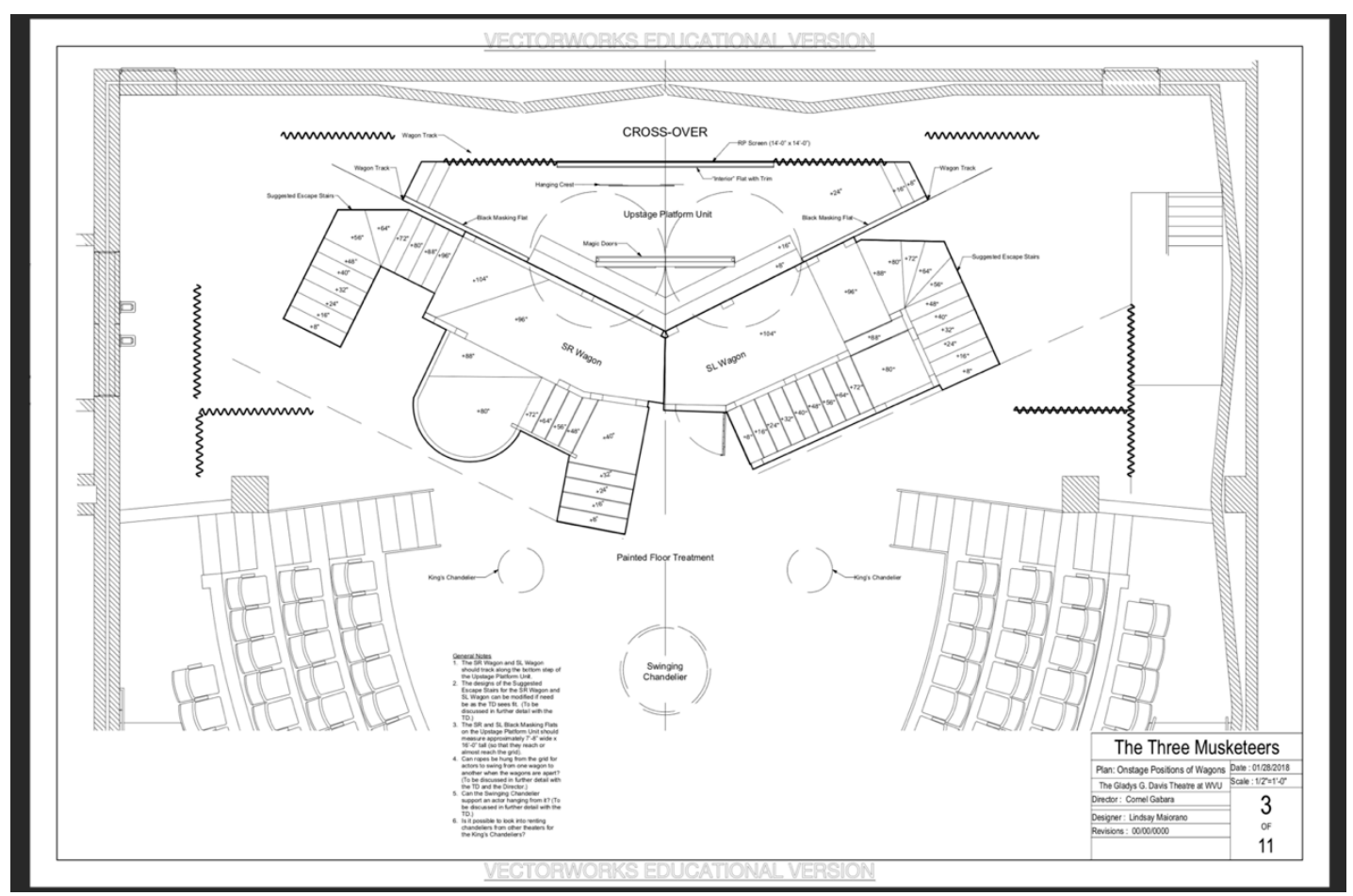

Figure 40: Drafting Plate 3 


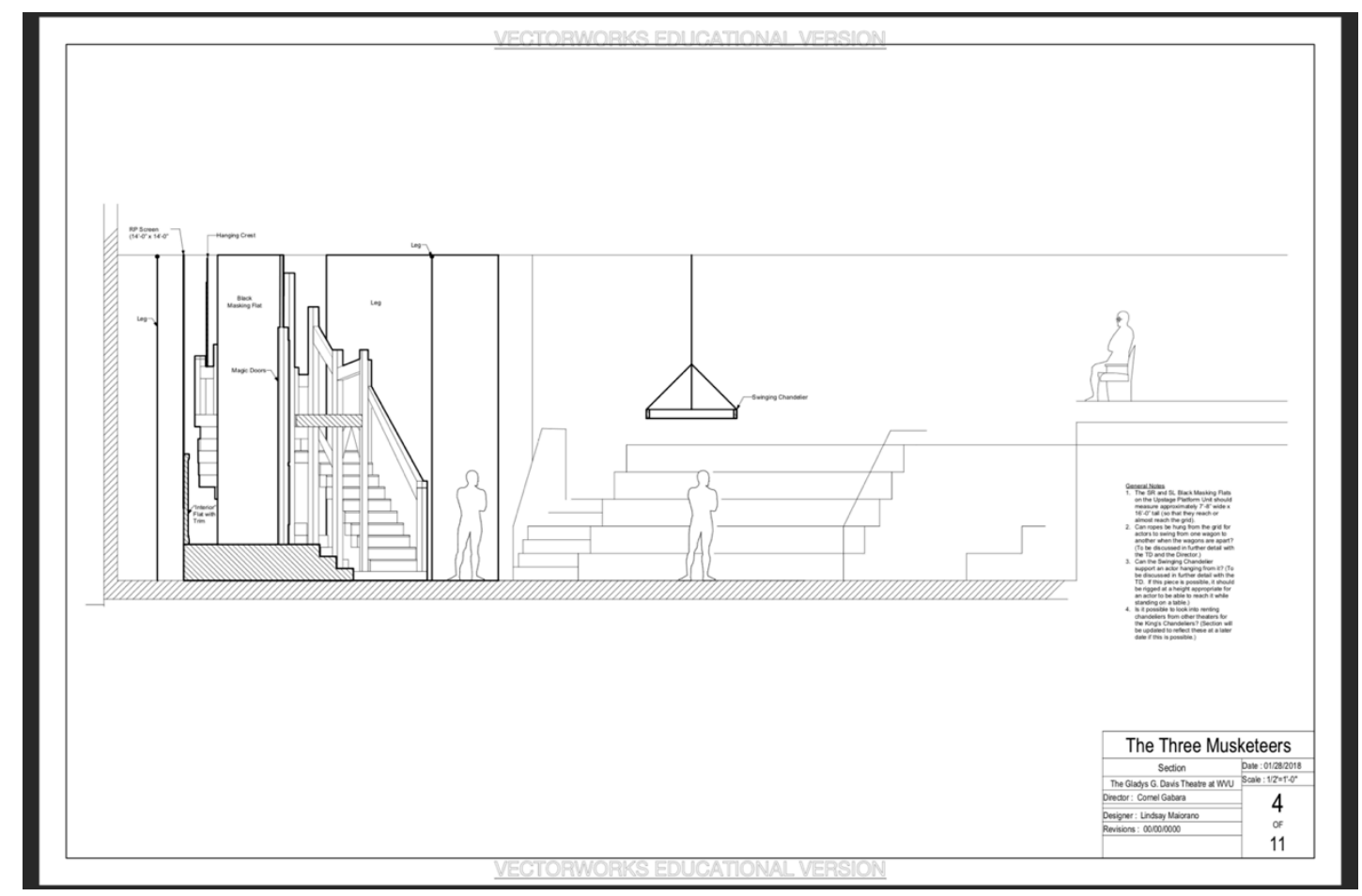

Figure 41: Drafting Plate 4

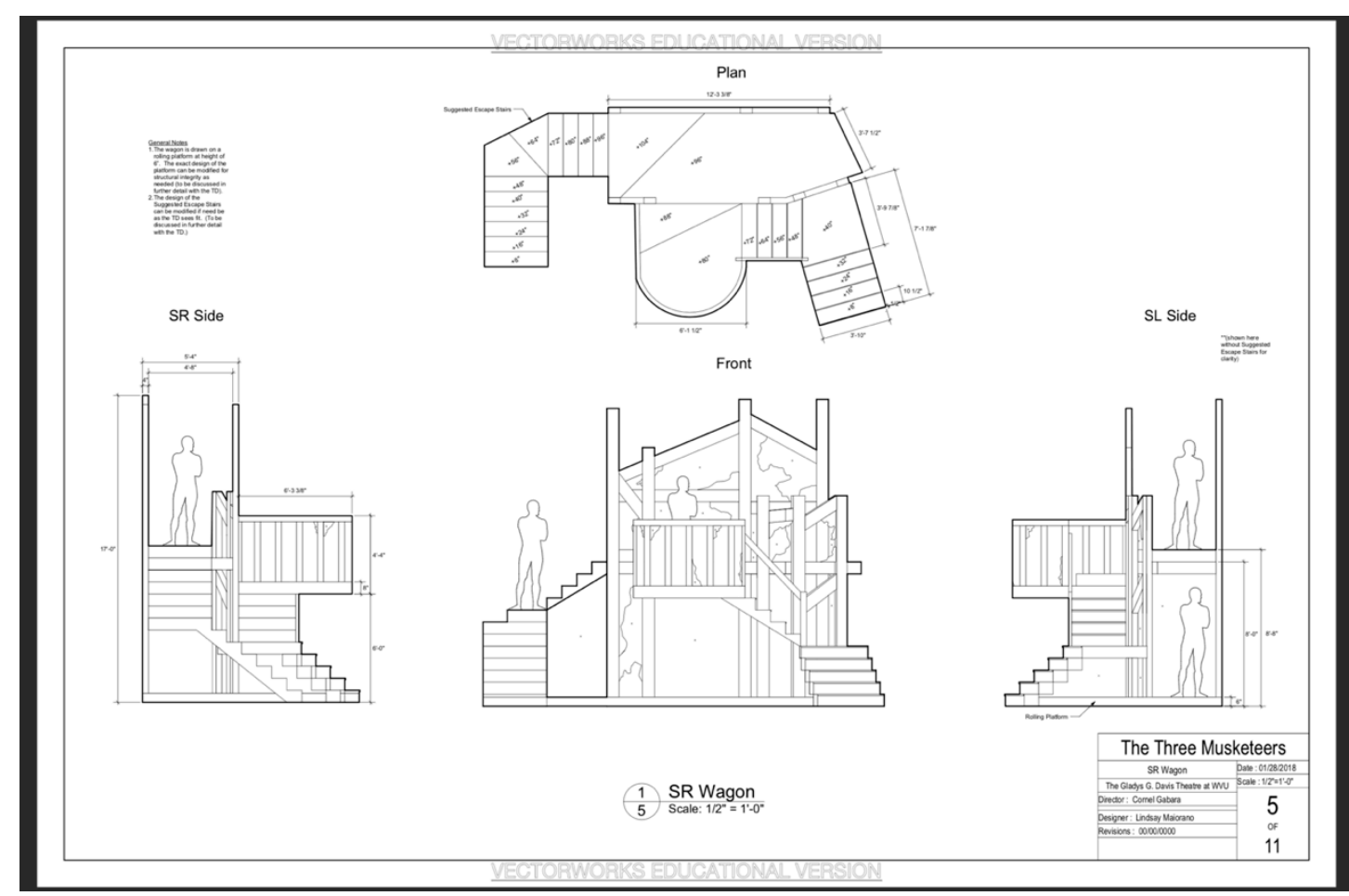

Figure 42: Drafting Plate 5 


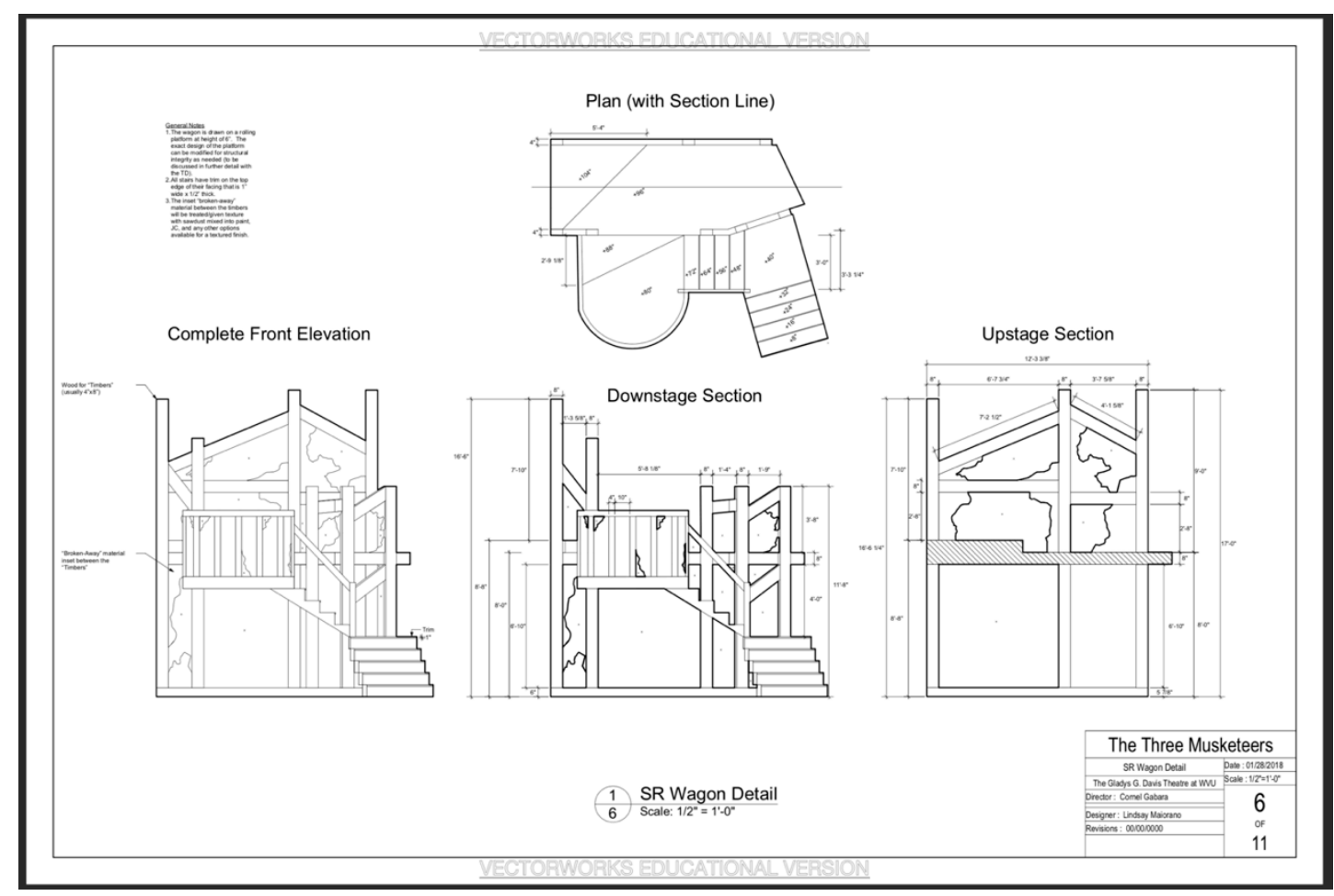

Figure 43: Drafting Plate 6

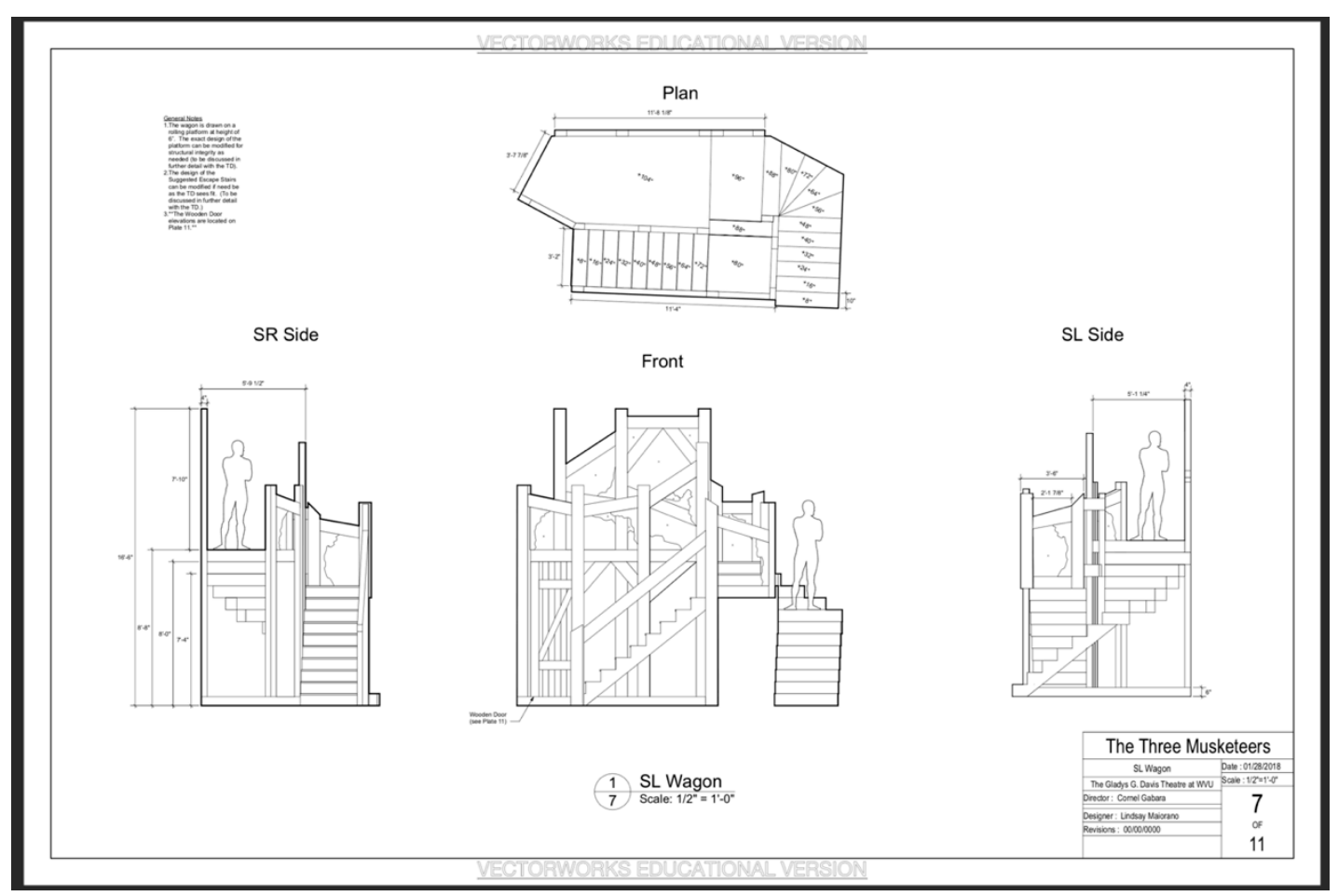

Figure 44: Drafting Plate 7 


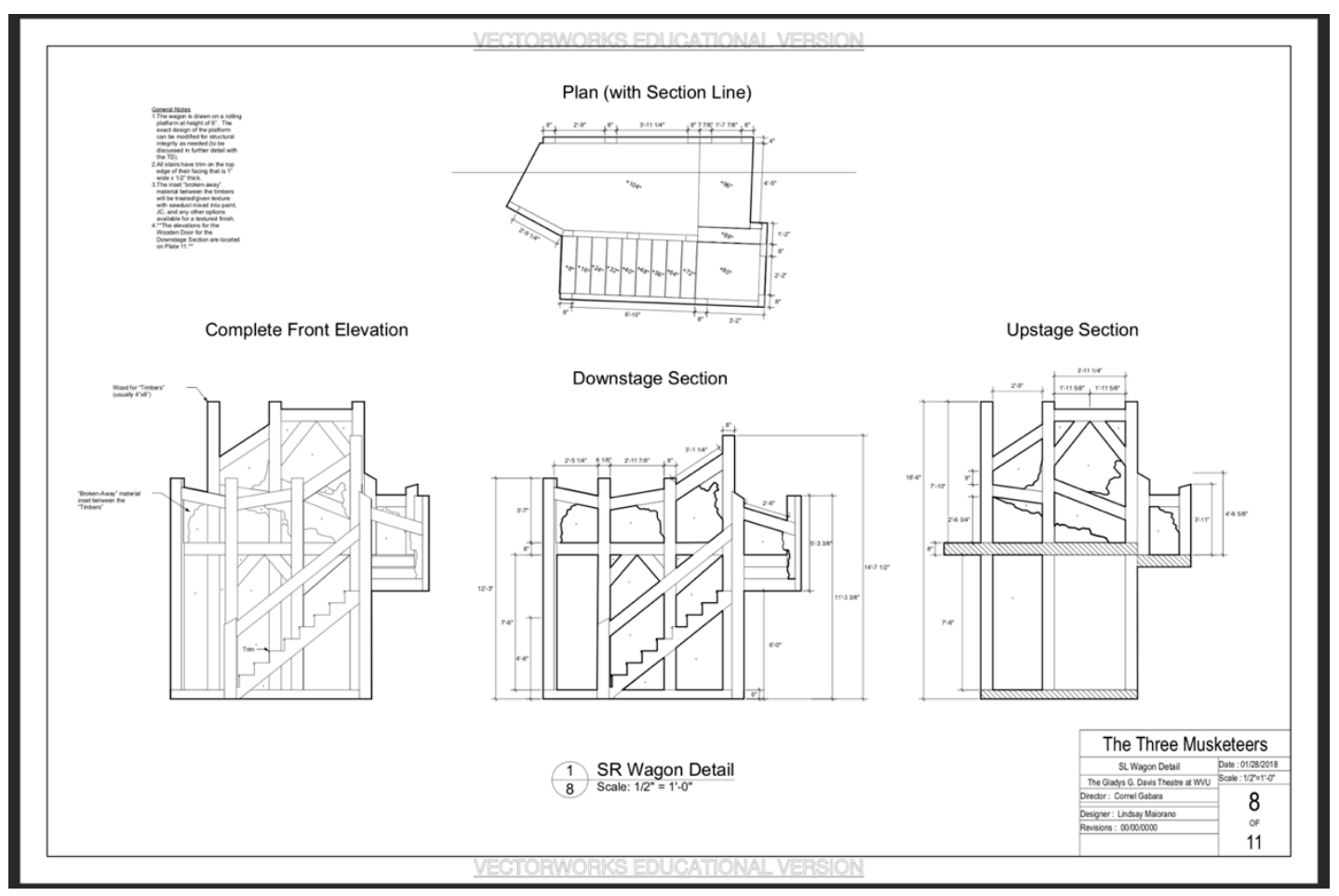

Figure 45: Drafting Plate 8

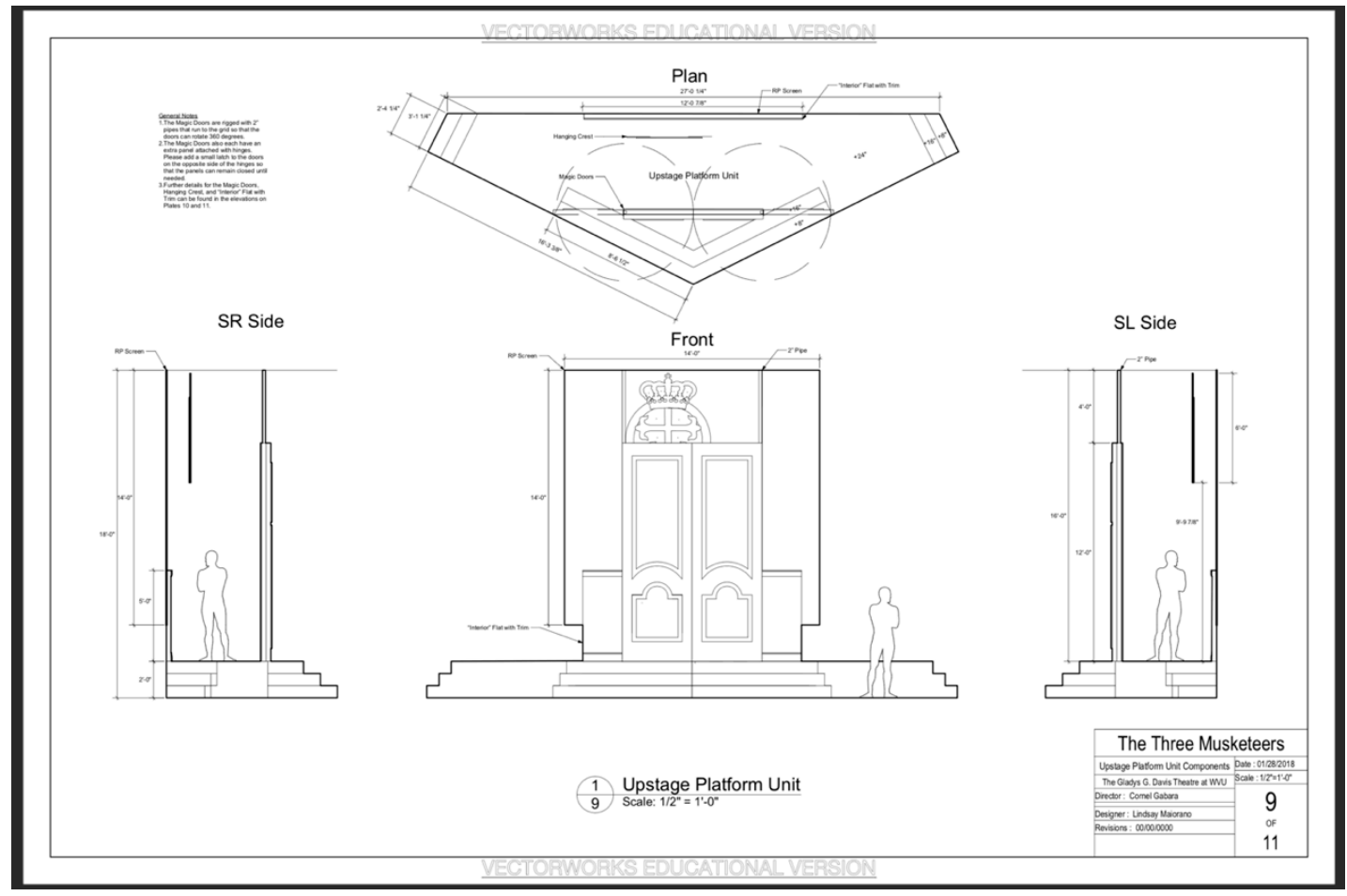

Figure 46: Drafting Plate 9 


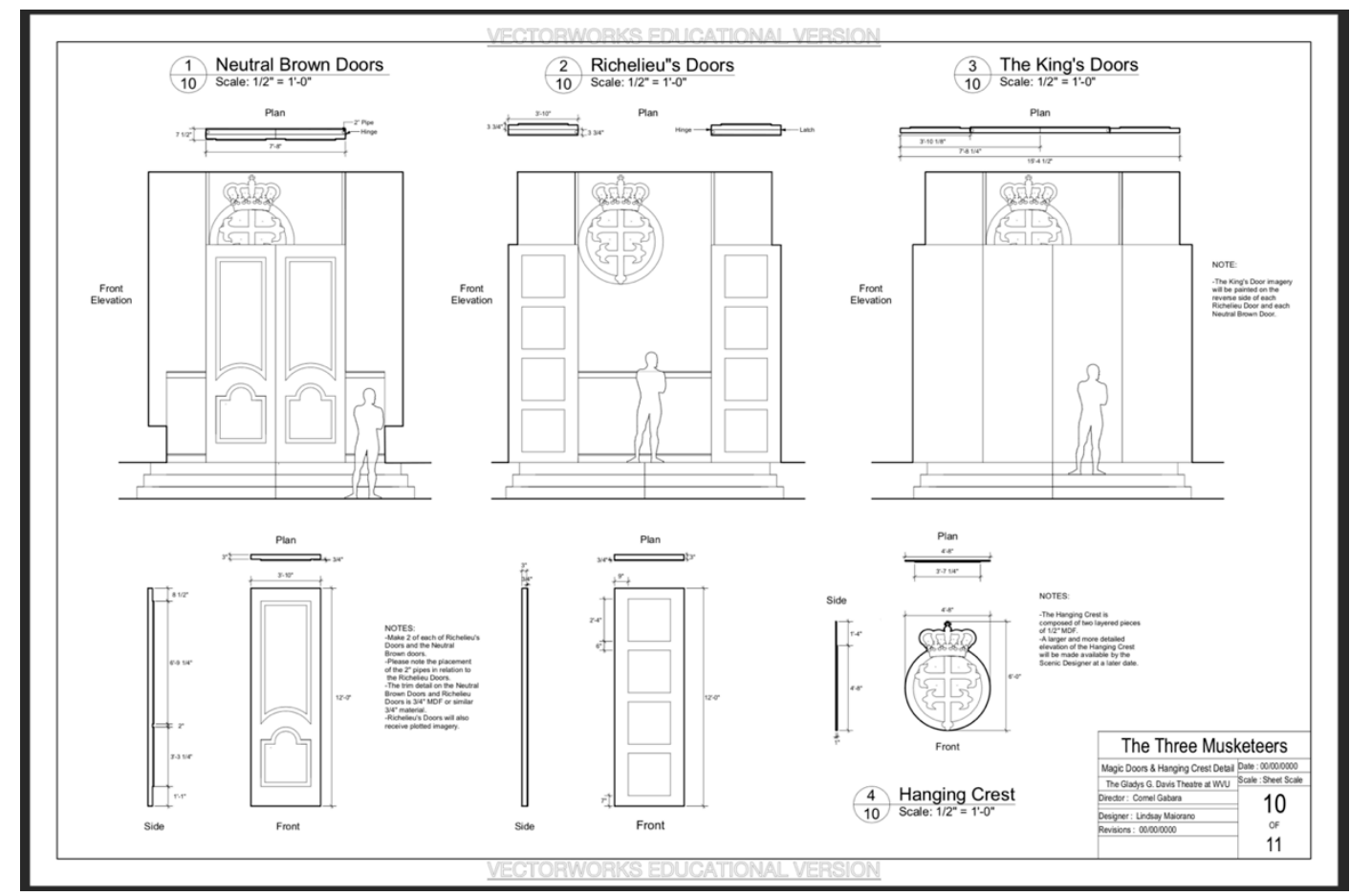

Figure 47: Drafting Plate 10

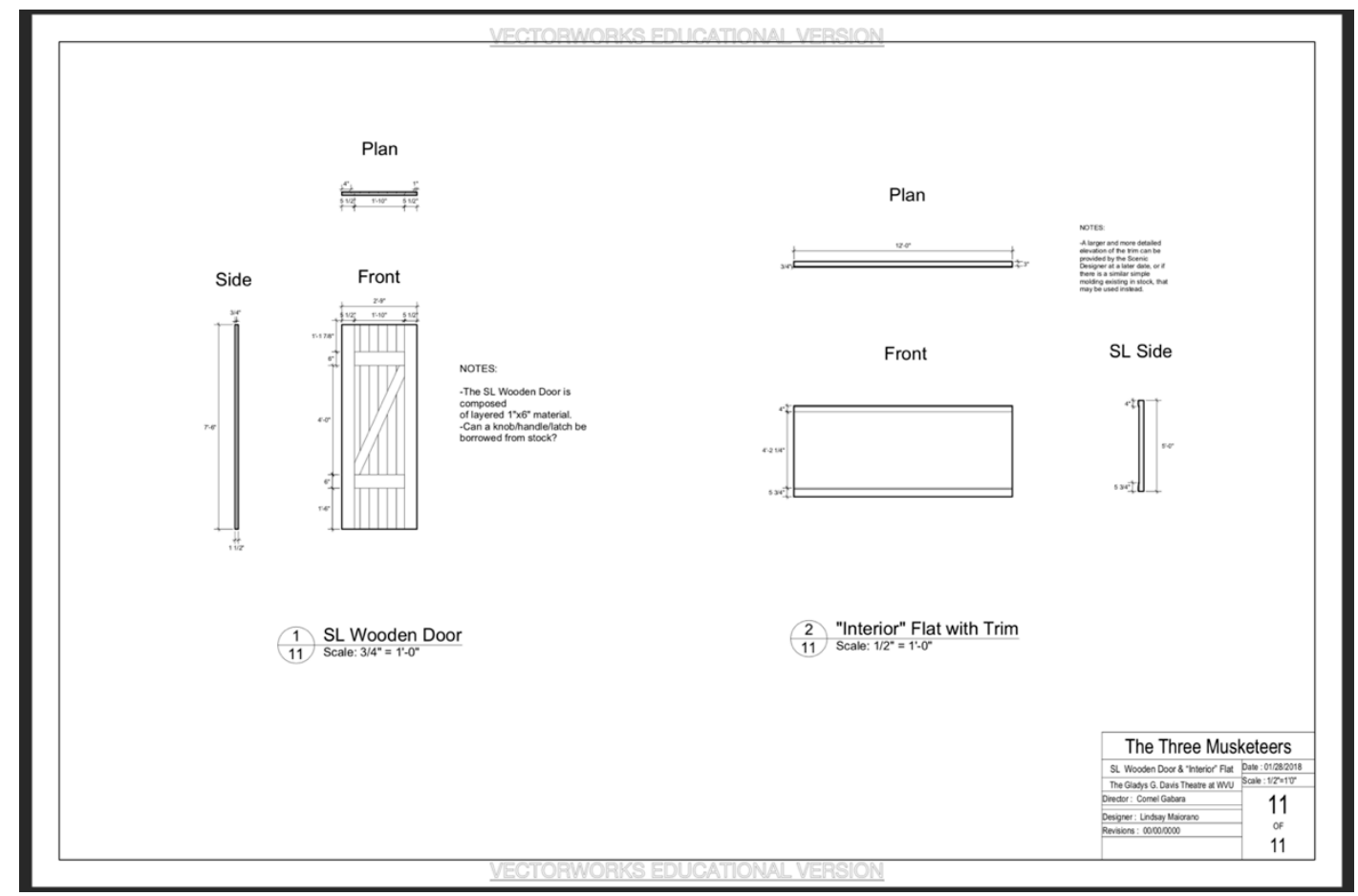

Figure 48: Drafting Plate 11 
Despite the fact that I had made so many mistakes along the way during the drafting process, this was an invaluable learning experience for me because at that time, it was the largest and most complex drafting I had ever produced, and it was rewarding to feel that after three rounds, I was finally able to execute all of the necessary information correctly. My irregular design for this show also called for more information to be communicated in greater detail to the Technical Director than I had previously had to include in any other drafting package. I learned that the more a set design can be broken down, the more helpful it can be to the technical director, because it always helps to provide thorough information even though it may seem (deceptively) redundant.

\section{The Final Photoshop Renderings}

Upon completion of the refined white model, I started an updated Photoshop file to reflect the progression of the scenic design by taking photos of the white model pieces and resizing them to fit properly into the photo of the Davis theatre. I started altering the color of the white pieces to simulate a brown timber texture and started to incorporate the Magic Doors (as seen in Figure 49), but these renderings had to take a backseat while I scrambled to complete the final technical drawings. 


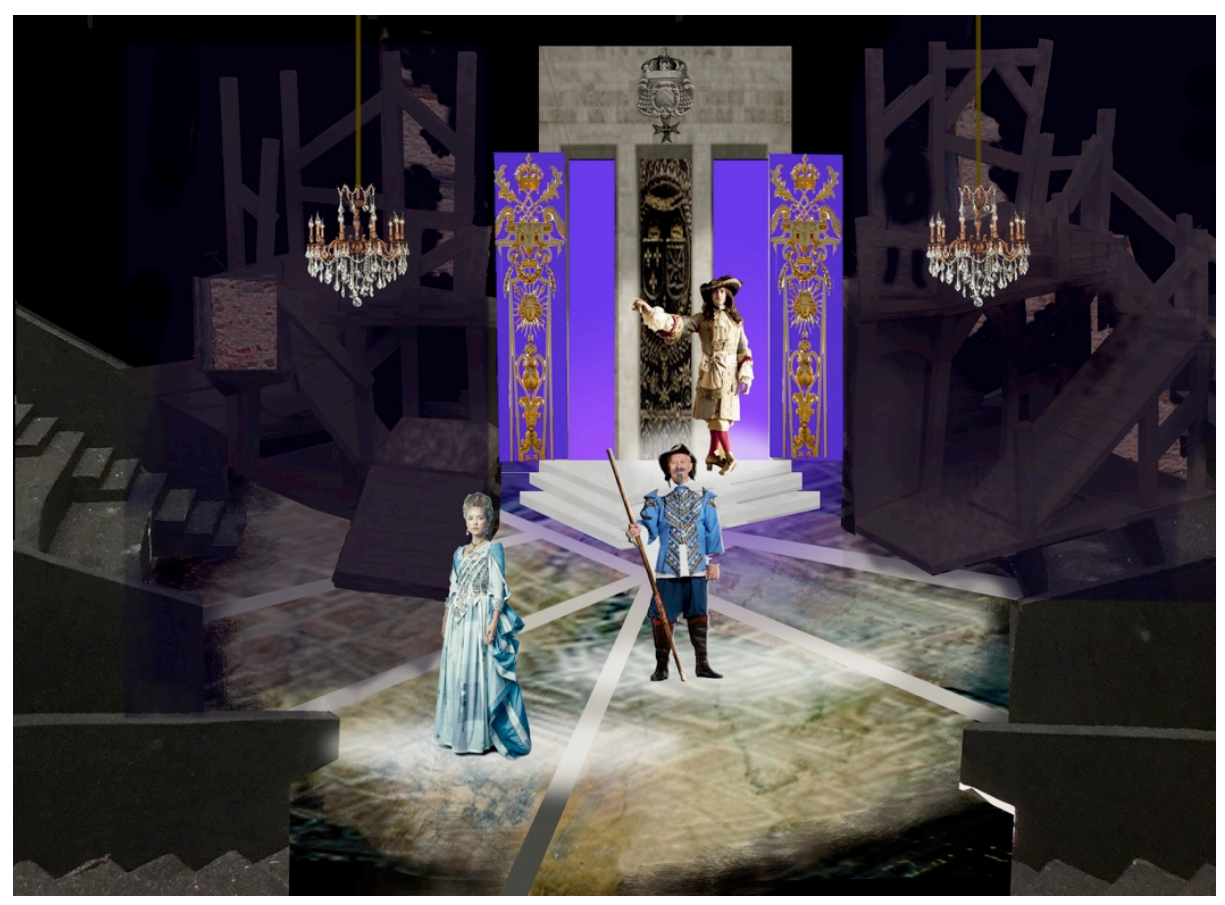

Figure 49: An In-Process Photoshop Rendering of a Slightly-Updated King's World

In our program, whenever final scenic designs are due, it is best to strive for Photoshop renderings of the set (if time does not allow for a completed full-color model), in addition to a full drafting package. However, it is most important to prioritize and turn in the drafting package so that the technical director can begin the budgeting and planning process. I knew I would not have adequate time to finish the white model, especially since the dimensions of all of the stairs had changed (these model pieces were no longer $100 \%$ accurate). I aimed to go back to the Photoshop sketches once my draftings were in good shape. However, Professor Klingelhoefer noticed the amount of drafting that I still had to do and offered to help me clean up the renderings while I focused on the drafting package. He mentioned that he knew other graduate design programs often assigned students to act as assistant scenic designers, and he said that our own program would operate the same way if we had more scenic design students. He acted as a collaborator on my renderings; I explained exactly what I wanted for every aspect 
of the design, and he would show me any progress he had made so that I could make any

adjustments. The final renderings are shown in figures 50-54. Professor Klingelhoefer's help in refining the Photoshop renderings was essential because my drafting ended up requiring my full attention in the time I had left. The renderings helped to communicate color choices and the overall look of the set to the director and other designers in a way that technical drawings could not.

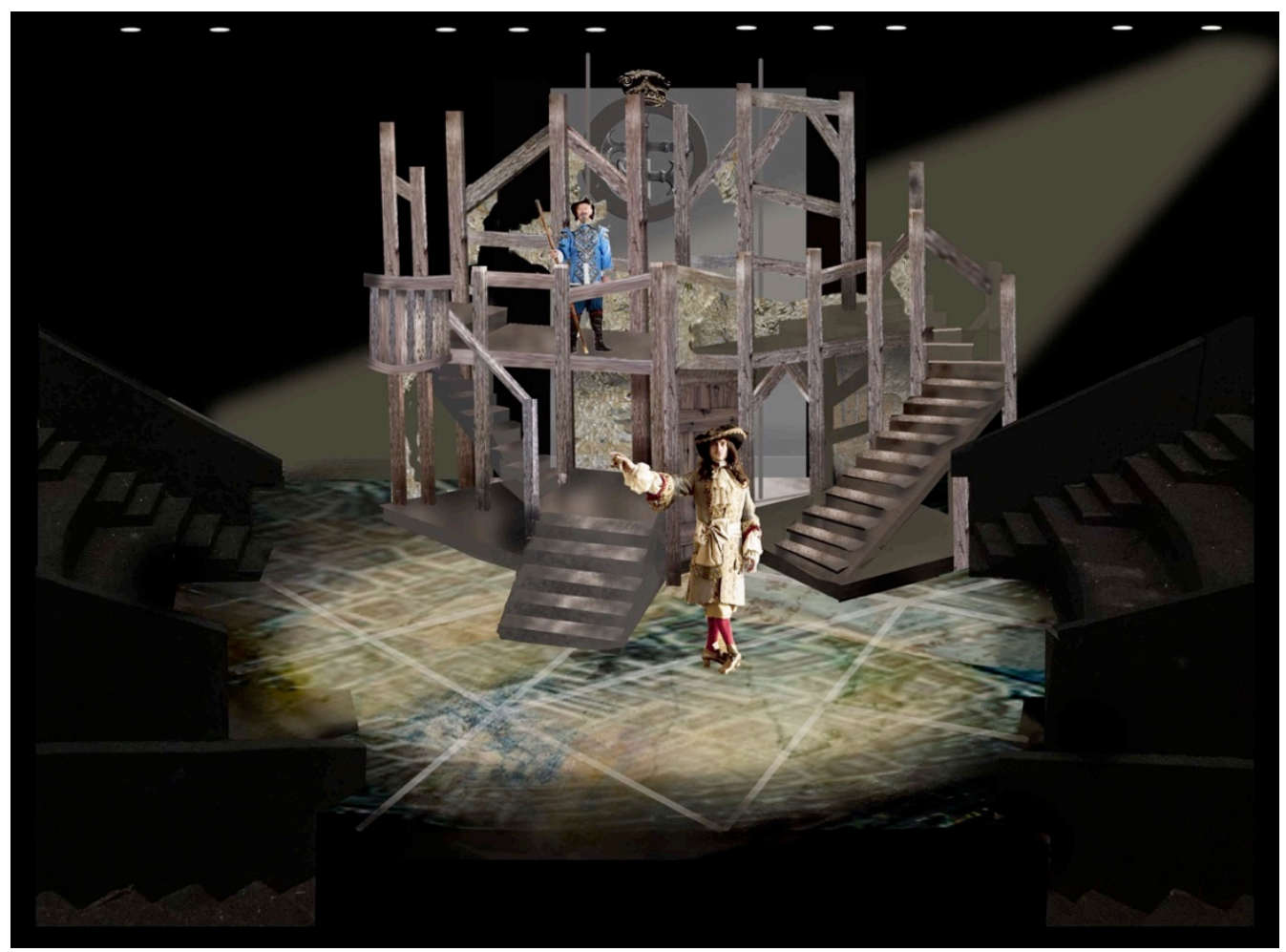

Figure 50: Final Photoshop Rendering of the Musketeers' World 


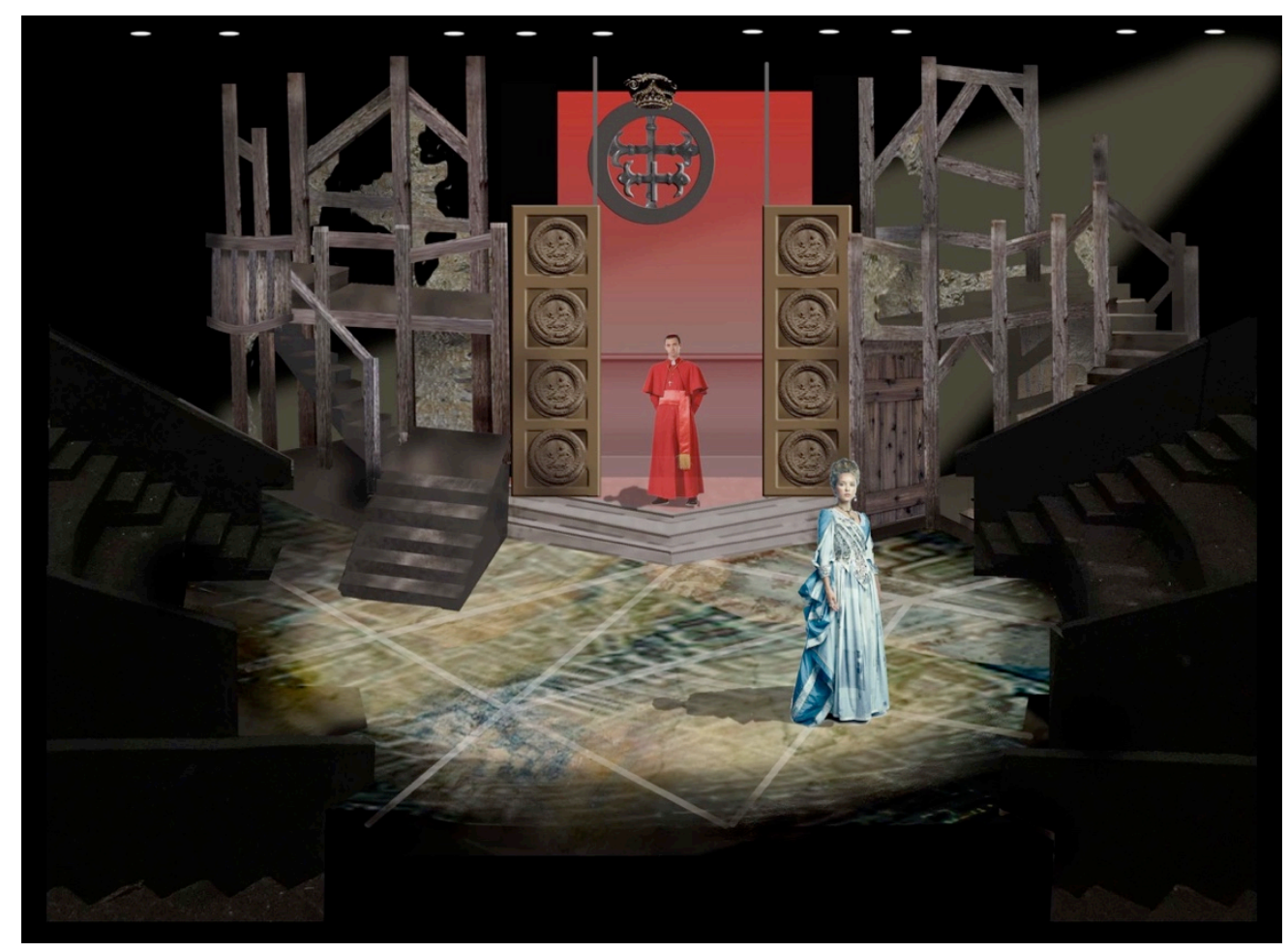

Figure 51: Final Photoshop Rendering of the Cardinal's World

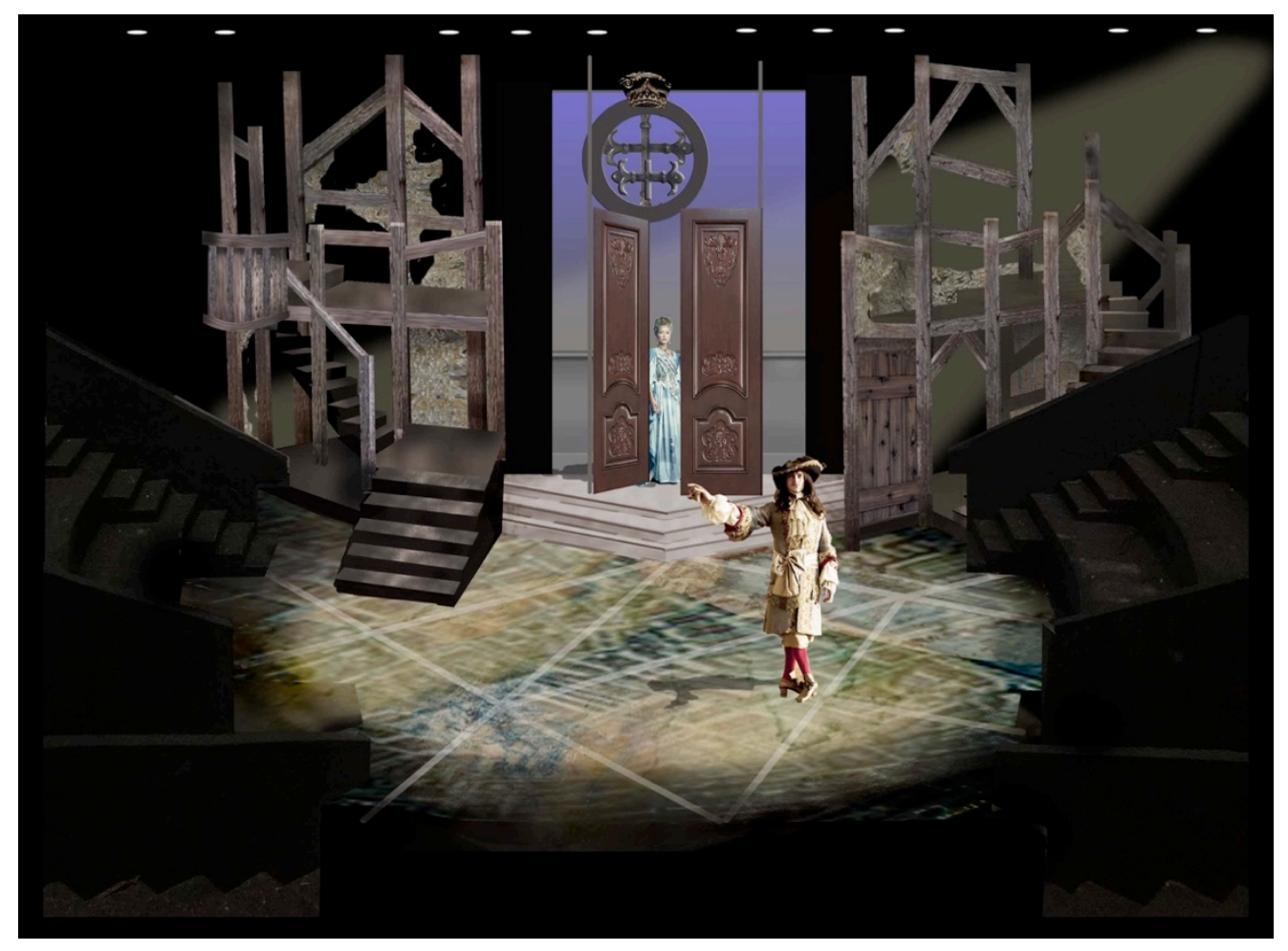

Figure 52: Final Photoshop Rendering of the Positioning for the "Neutral" Brown Doors Look 


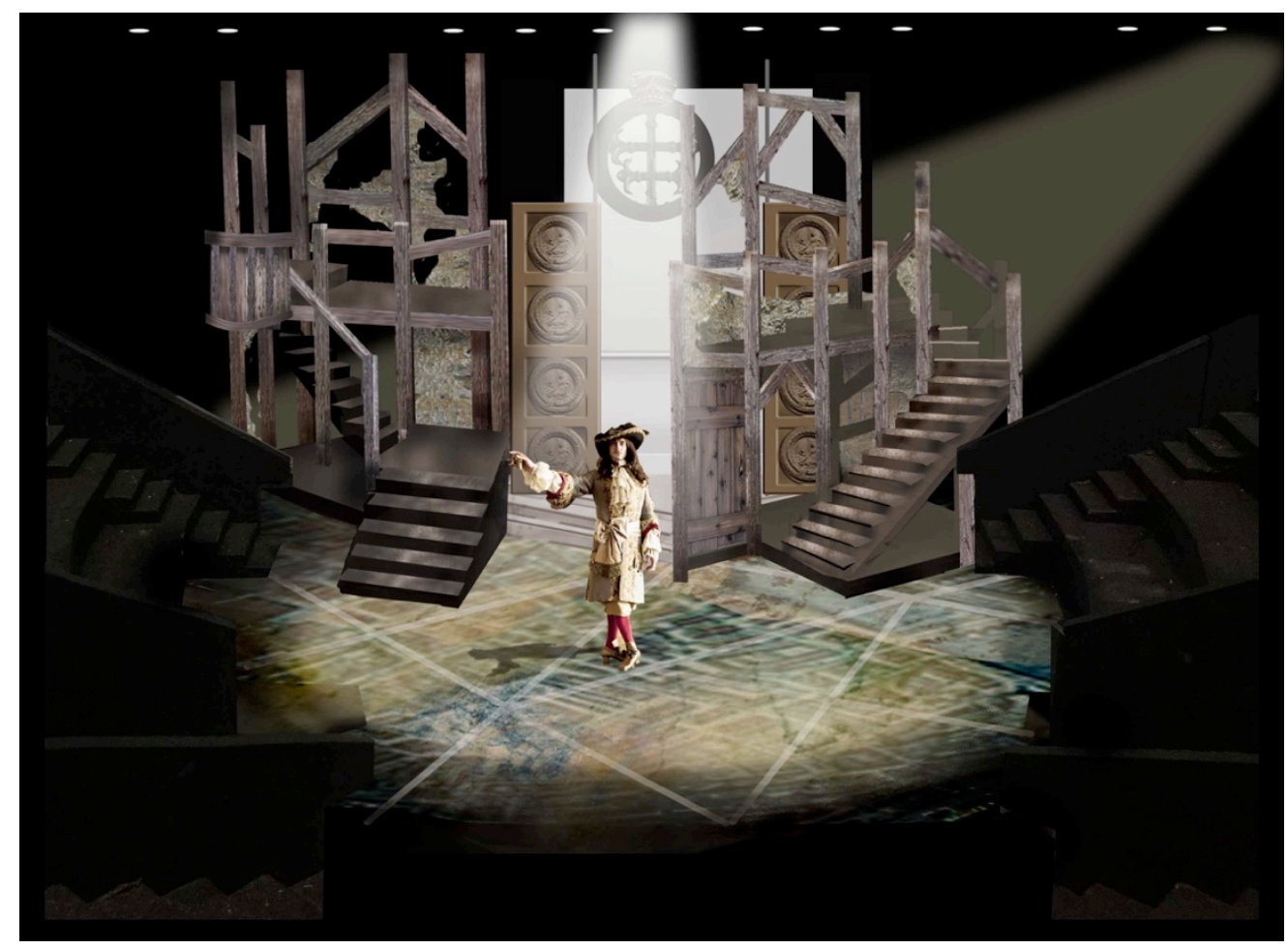

Figure 53: Final Photoshop Rendering Depicting Potential Asymmetrical Wagon Positioning

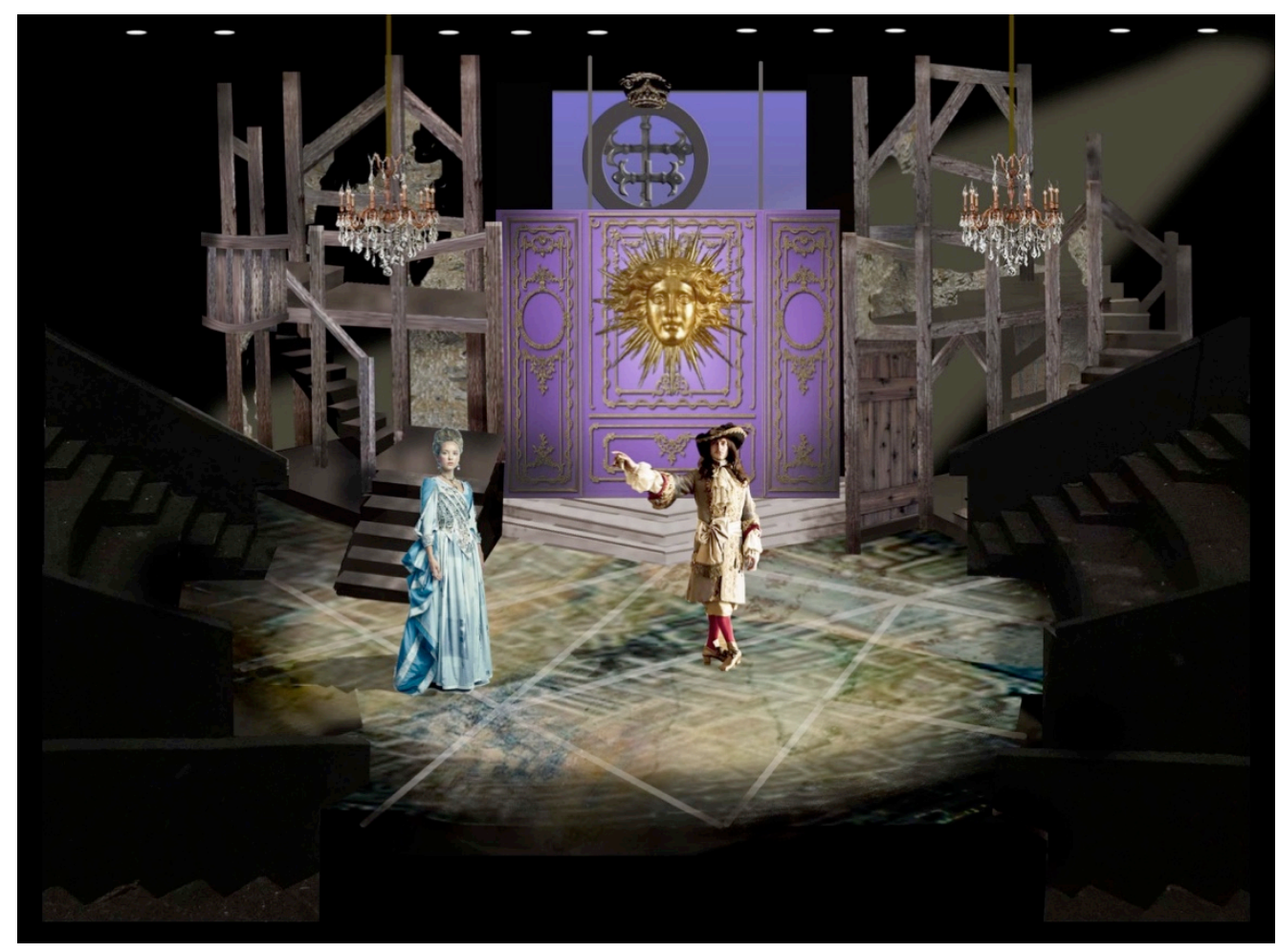

Figure 54: Final Photoshop Rendering of the King's World 


\section{The Final White Model}

After presenting the final renderings and handing in the drafting package, I was asked to recreate the refined white model of the wagons to the actual dimensions indicated in the drafting, again because the measurements of the stair units had all changed. The purpose of this was so that the Technical Director, Skiba, could refer to three-dimensional examples of the wagon units if he needed to see aspects of the pieces that were not visible enough in the drafting. I was able to create these new, accurate pieces (Figures 55-58) quickly over the next few days while Nick started his budgeting process. In retrospect, I was really happy that I provided these revised models for him, as they proved to be very helpful to his planning process. There were multiple times in which I saw Skiba in the Design Room measuring different parts of the model pieces as he started his build drawings in AutoCAD (another drafting software available to designers and/or builders), or referred to them throughout the actual building process. 


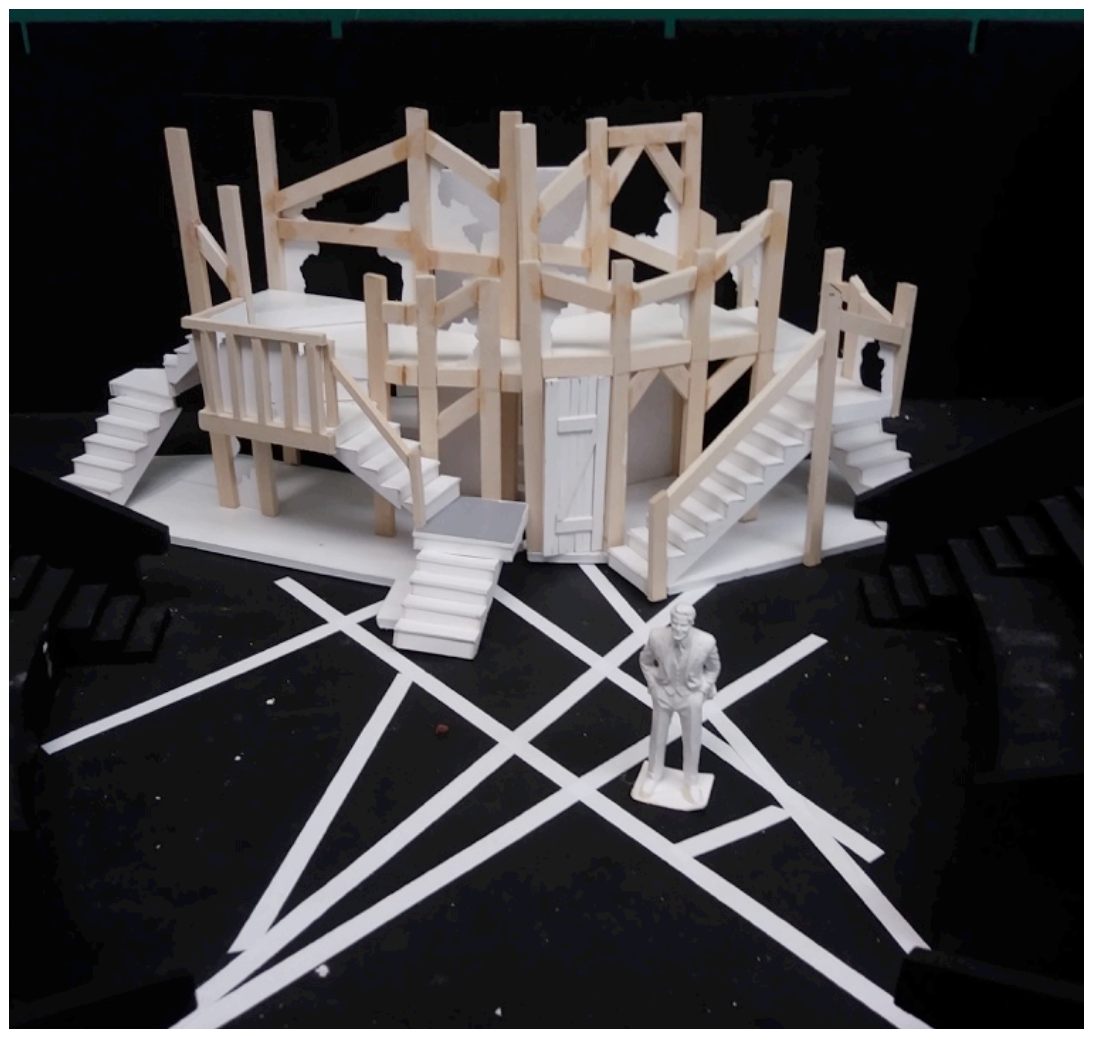

Figure 55: Final White Model-The Musketeers' World

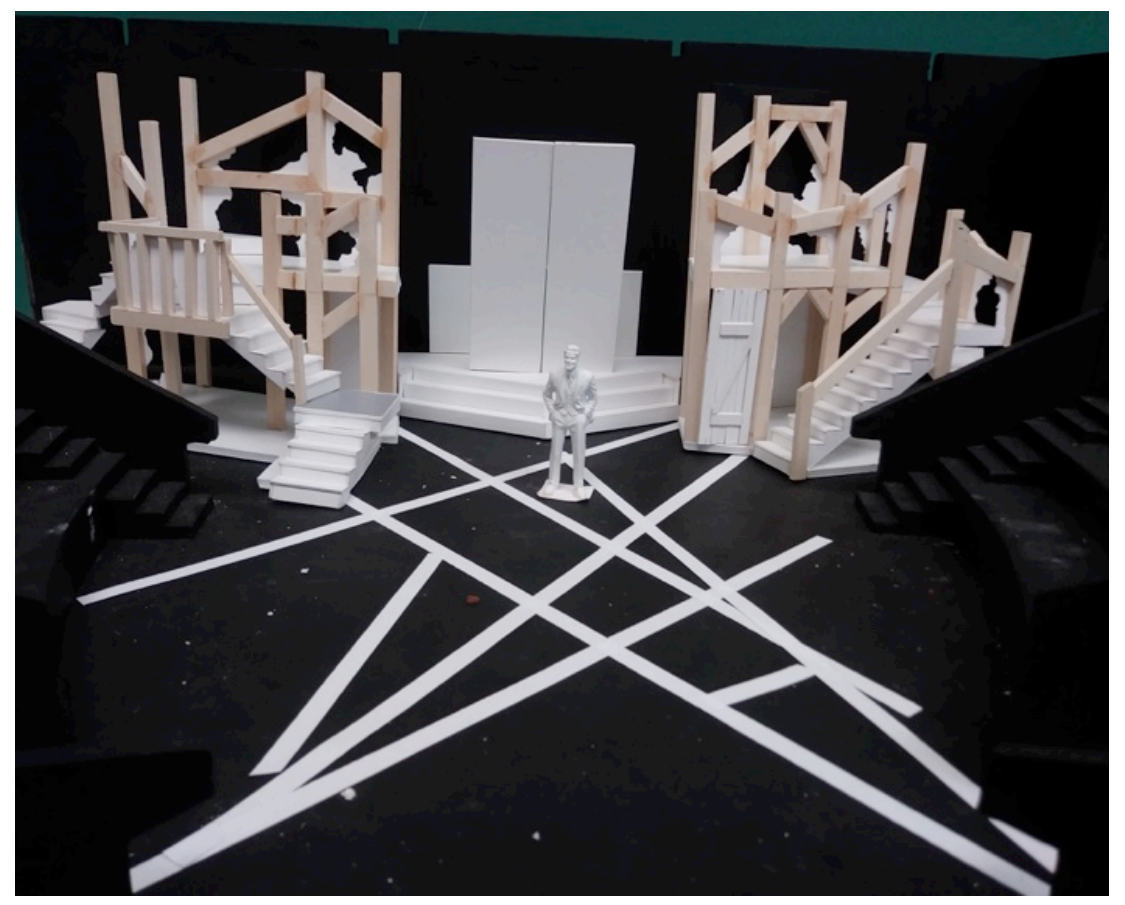

Figure 56: Final White Model-The "Neutral" Brown Doors Look 


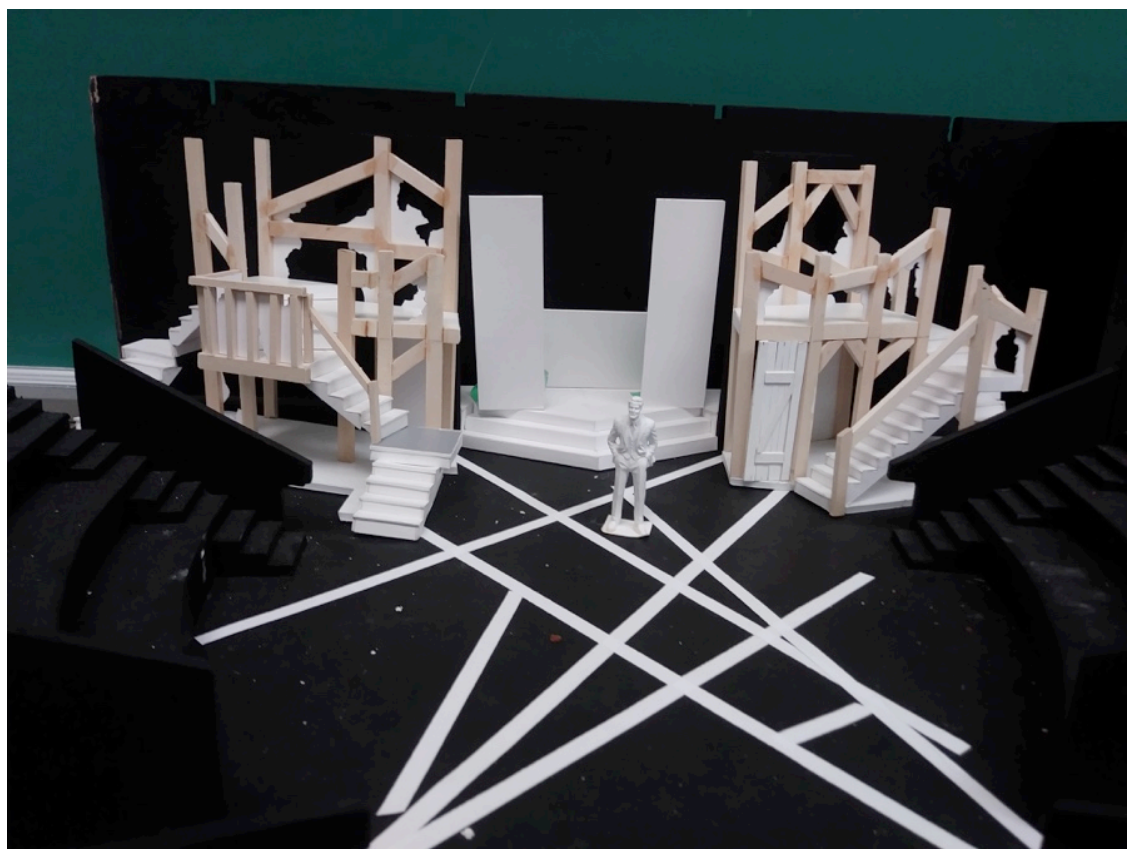

Figure 57: Final White Model-The Cardinal's World

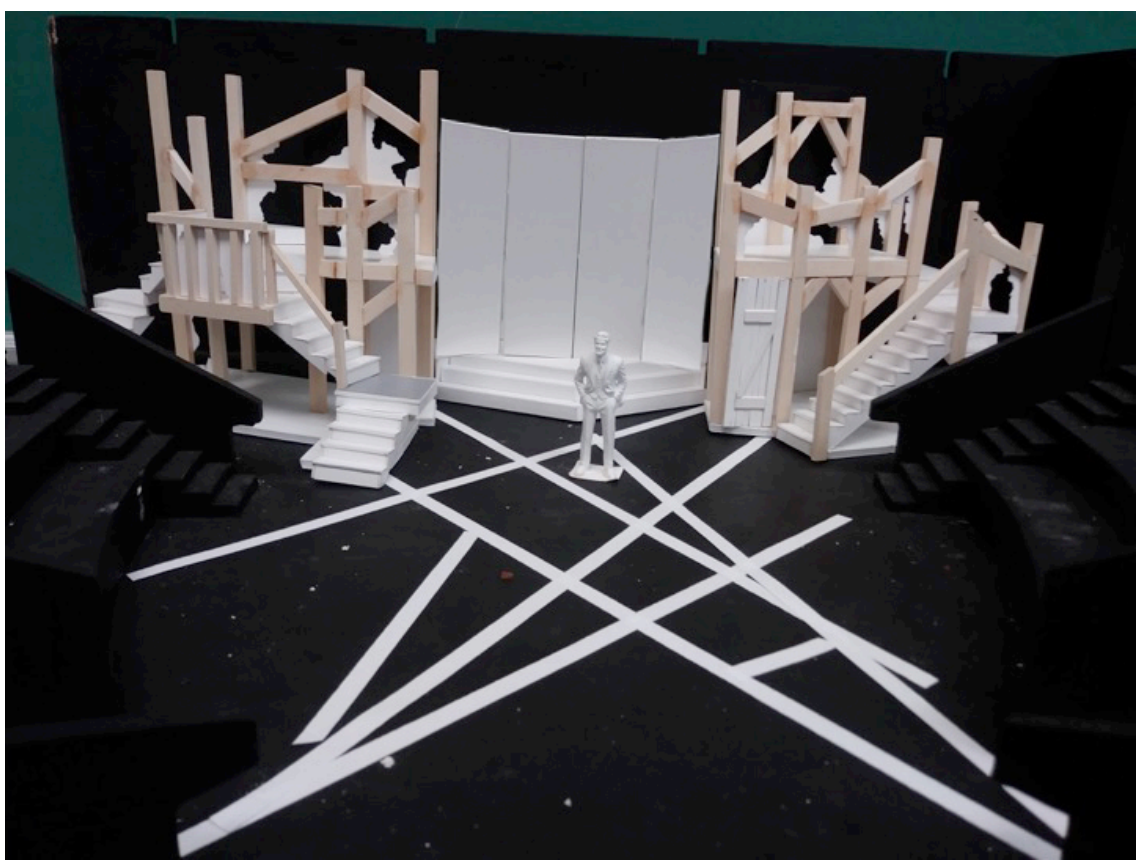

Figure 58: Final White Model-The King's World 
This model also became a valuable tool during early rehearsals for Professor Gabara. I used chalk to indicate the onstage and offstage positions of the wagons on the floor of the Davis theatre model box, as well as the intended positions for the masking legs. Professor Gabara also requested that I make sixteen half-inch scale model figures so that he could figure out blocking and fight choreography with the desired amount of actors in the model box during the early rehearsal process. 


\section{Part III. Design Execution}

\section{The Budgeting Process}

Nick scheduled a meeting with me after he had gone through all of my designer drawings to let me know where the set stood in terms of our $\$ 5,000.00$ budget. We were only over by roughly $\$ 1,000.00$ at the start of our meeting, so we discussed eliminations and possible substitutions to alter the design and bring it back within our budget frame.

The first thing we decided to cut was the zip-lines. It would have been too expensive for an effect that would most likely only happen once or twice during the show; the rest of the set was more important. There was also the issue of pinning down an exact location for the ziplines. We realized that the lines would always be visible during the show no matter where we placed them and would cause unsightly shadows that would be problematic for the Lighting Designer, Thomas Gillette, to work around with his light plot. Since the wagons were not designed to be static, that eliminated the possibility of securing the destination ends of the ziplines to the wagons, and there was no better option of where to place them in that space and in those circumstances. While it would have been an exciting effect to enhance the adventurous nature of the story, as well as a learning experience in terms of technicality and practicing actor-safety, this was the obvious item to eliminate first.

We also made some minor adjustments to the designs on the Magic Doors, such as reducing the size and amount of molding on the Neutral side and the Cardinal's side. The molding was going to be constructed of medium-density fiberboard (MDF), which is a relatively expensive material but is ideal for constructing molding and trim due to its smooth finish and ability to be easily routed into different shapes. Sometimes even the most minor modifications 
to the amount of MDF in a design can be surprisingly beneficial to retaining budget. I was able to easily compromise on a reduction of MDF while still being able to preserve the spirit of the doors' original design detail.

After these adjustments, we were still over our budget by a few hundred dollars, and if I did not cut the Swinging Chandelier, I would have had to either completely alter the wagons or the vertical upstage unit. Having already drafted the wagons three times, I had no desire to change their design again, and I did not feel as though the upstage unit could become any more stripped down. Similar to the issue of the zip-lines, I knew that this effect would most likely only be used once during one of the tavern fights, and although I would have loved to have a set piece become directly determinant of a move in a fight, I knew cutting it was the right decision.

Cutting the Swinging Chandelier brought us back just under budget until we realized that we never factored in a pair of fancy chandeliers that I included in my renderings for the King's ball scene. I had previously made a note of this detail in my drafting, but did not have time to source an exact product to incorporate in our budgeting. I told Skiba that I would attempt to find a pair of chandeliers to rent inexpensively or borrow for free from nearby theatre programs at surrounding schools, and I began sending out some emails that same day. I first contacted the props master of the theater department at Carnegie Mellon University, but they did not have anything in their stock that was similar to what I was searching for. Next, I reached out to Troy Snyder, Professor of Theatre Arts and Props Master at Fairmont State University. He quickly responded with an offer of a pair of chandeliers that were perfect for the 
King's ball. Gillette went to go pick up the chandeliers in Figure 59 (loaned to us for free) just prior to our load-in week.

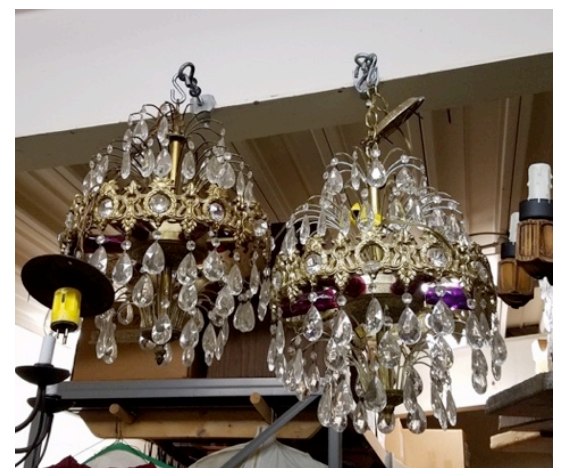

Figure 59: The Chandeliers I Borrowed for the King's Ball Scene

The last element that we discussed was the potential of rigging swinging ropes in the set for the actors. This seemed to be a very cost-effective option towards preserving an effect similar to the zip-lines and Swinging Chandelier. However, Skiba and I found that the ropes still presented the same problems as the zip-lines. We discovered the lines of the ropes would still interfere with the lighting design. In addition, the fact that the wagons were not static presented an installation issue. The ropes would have been rigged to the grid and everpresent, so they could have seemed awkwardly-placed as the wagons rolled into different positions onstage.

Having completed the budgeting process, we were ready to begin constructing and realizing the approved scenic design.

\section{The Build \& Scenic Art Processes}

The Three Musketeers was scheduled to be the third and final production during that spring semester, and I had noticed a trend during my time at WVU that the last show of the semester tends to be the most hectic build. This is often because the build calendar for the first 
two shows can sometimes change by taking longer than expected, which then affects the start date for the build of the next show. The build for The Three Musketeers also started at an unfortunate time because our department participates in two national theatre conventions each year that are often scheduled in the spring within one week of each other. Our build started just as I left for the Southeastern Theatre Conference (SETC) in Alabama with James Raymond, the other scenic design graduate student. Raymond and I were assigned as Scenic Artists for this show. Skiba had begun the building process just prior to our departure by creating the upstage stepped pyramid base, and I started to get the scenic art process for that piece underway. Raymond and I worked at getting the majority of the white marble paint treatment on the platform before we left, and I asked another scenic artist in our department, Rebecca Smith, to sponge gloss sealer intermittently over the whole unit. She texted me some photos of the platform while I was away and expressed concern because the sealer was apparently yellowing over the pristine white base coat. I asked her to stop working on it so that I could see it in person when I returned, and Raymond and I finished working on the platform after our trip.

Meanwhile, Skiba started constructing the stage right wagon, texting photos of his progress along with questions. As mentioned earlier, the timing of the theater conference trips was only the first obstacle during the build process. Just as Raymond and I returned from SETC, Skiba and several other design/tech students attended the United States Institute for Theatre Technology (USITT) conference in Florida. The wagon Skiba had started building was not ready to be painted, so the only piece that could be painted by that point was the stepped pyramid 
platform. As mentioned, Skiba and the other students were at USITT during the remainder of Spring Break, so both the build and scenic art processes were at a temporary standstill.

\section{The Theatre Floor Treatment}

Another event that was scheduled on a Saturday around the same time was the West Virginia High School Thespian Festival. Even though our school did not host the festival as it had the previous year, our department was still required to travel two hours away to organize a Technical Theatre Rodeo game as a recruiting opportunity. Coincidentally, this happened to be the best weekend for me to paint and seal the elaborate floor treatment since there were no other events scheduled in the Davis theatre, so I was exempt from participating in the festival. Raymond was still required to travel to the event, so I did not have his help in the early morning, but he joined me in the late afternoon and worked with me until the late evening. Luckily, we were able to base the floor together the previous day, which saved me a lot of time while I was working alone. I had also mixed all of our floor colors and came up with a plan of attack throughout the week, so I was able to draw the layout of the "street lines" on the stage floor until Raymond returned.

Figure 60 depicts the Photoshop rendering of my abstracted map floor design. Some of the pre-mixed colors are shown in Figure 61, and Figure 62 shows a glimpse of the layout process. 


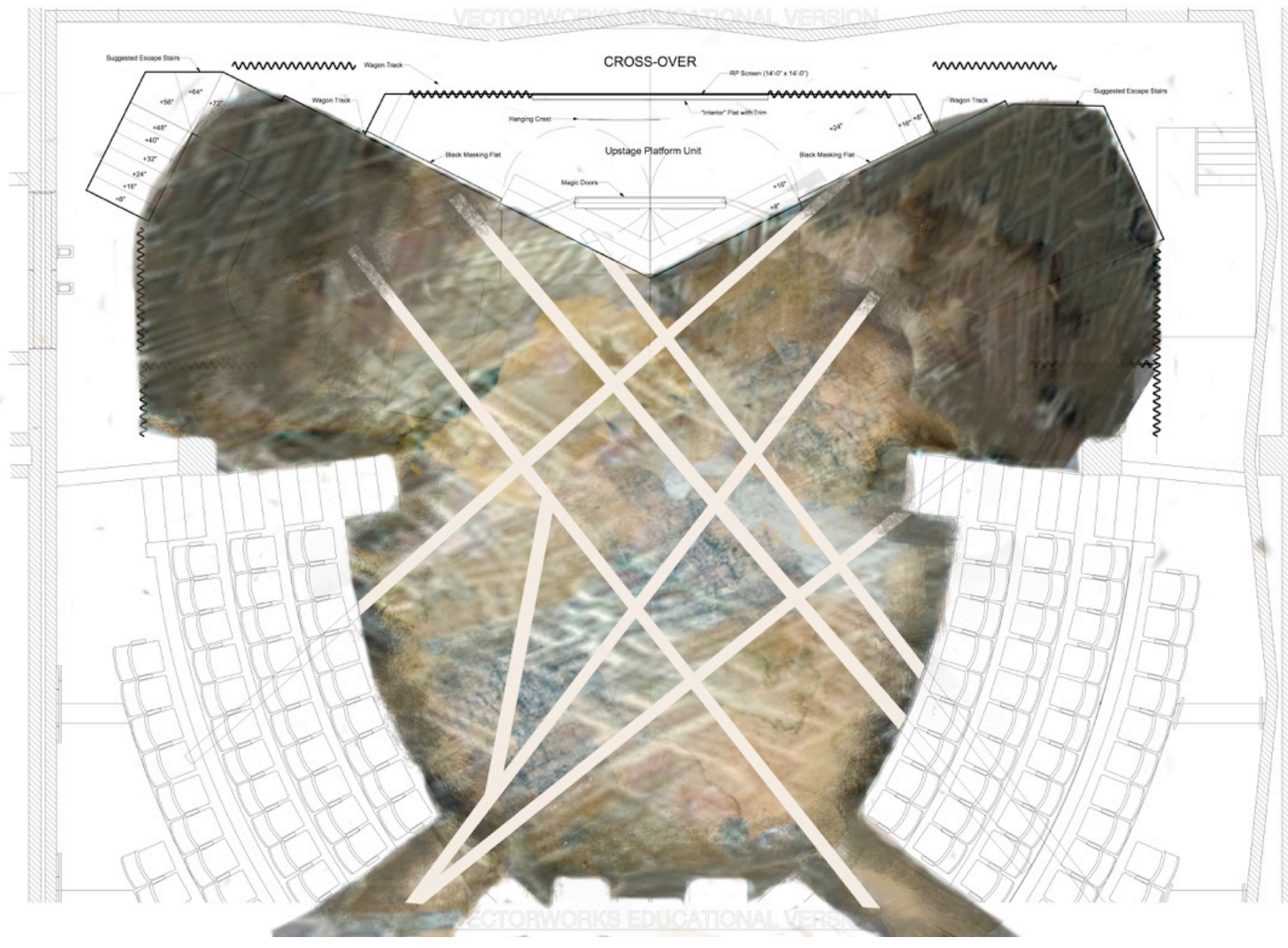

Figure 60: Digital Paint Elevation of the Abstracted Map Floor Treatment

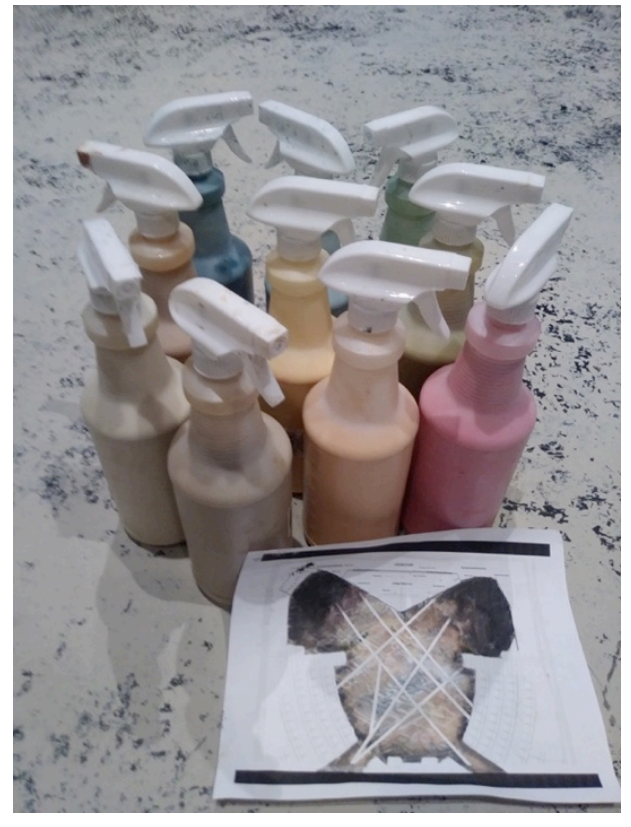

Figure 61: Mixed Paint Colors for the Floor Treatment

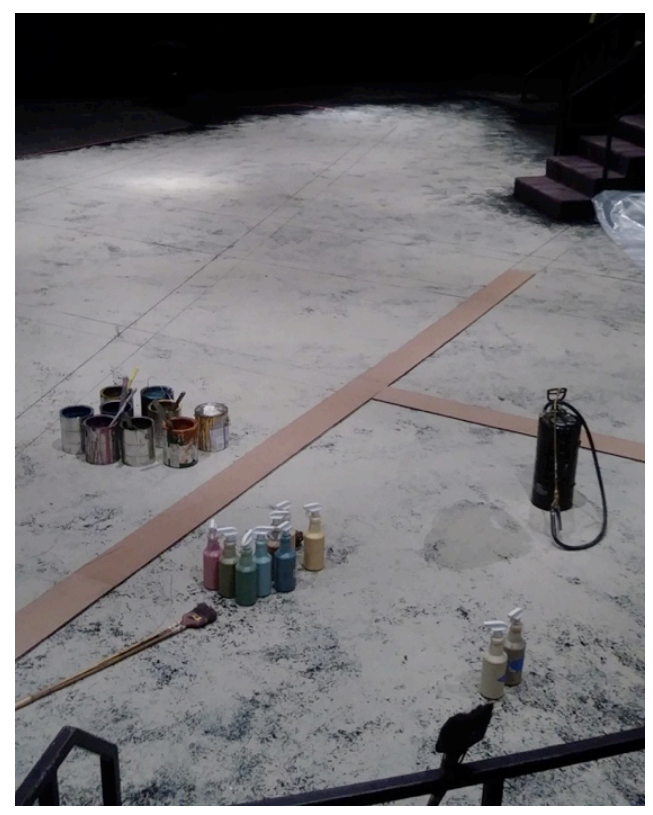

Figure 62: The Layout Process of the "Street Lines" 
When he came back from the trip, we each worked on different sections between the intersecting lines, working downstage to upstage. As seen in figures 63 and 64 , we covered the intersecting lines with scraps of lauan to preserve the layout and painted around these scraps as we moved along. I instructed Raymond to first apply a light spray of water to each section with the Hudson sprayer, then mimic the colors and abstracted shapes shown in the rendering with a brush, and finally apply more water if needed. We knew we had to completely finish the floor treatment over that weekend so that the scenic and lighting load-in and rehearsals could commence on Monday, which meant we had to work quickly. I told Raymond not to worry so much about completely copying my rendering, but rather to use it as a guide to capture the spirit of the floor treatment.

The benefit of an abstract paint treatment is that it can enable scenic artists to take liberties with the paint application without harming the end result. Using a lot of water in the process enabled Raymond and I to work quickly. The water broke up the paint where we applied it, which resulted in a really interesting variety of markings and effects that would have taken forever to try to replicate if we had attempted them by hand. Several times as we worked, we both commented to each other how enjoyable the process was. Painting the expansive floor in the Davis theatre can be an intimidating and exhausting undertaking, and we were pleased that it ended up being a liberating and quick endeavor. 


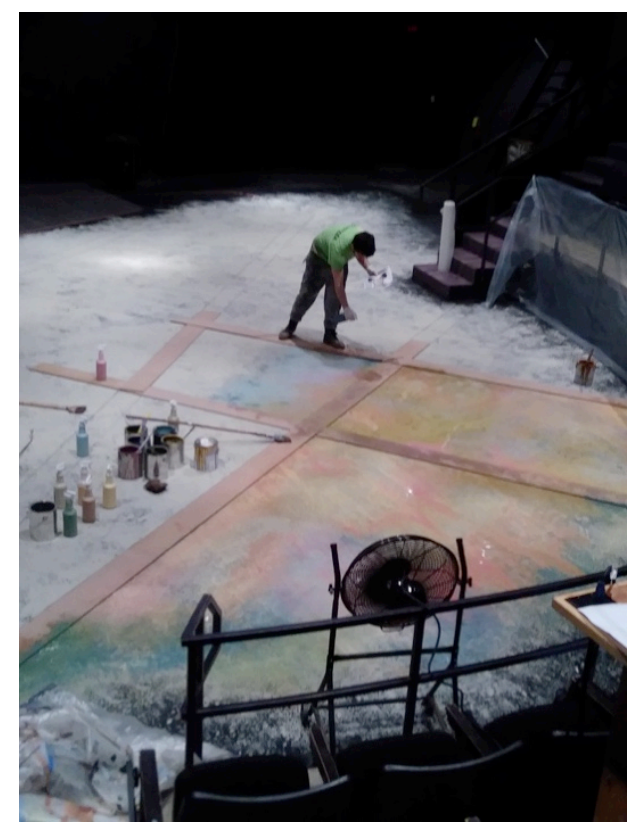

Figure 63: Painting the Theatre Floor

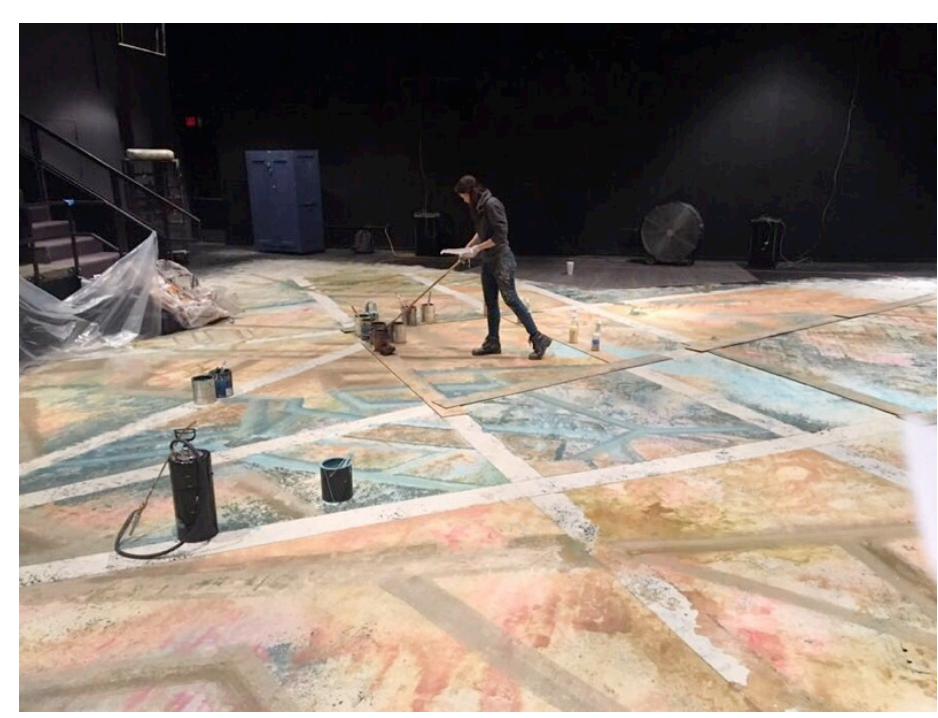

Figure 64: Painting the Theatre Floor

After we had finished adding the color into the upstage areas, we let the puddles of watered-down paint on the floor continue to dry overnight and returned the next morning to clean up the lines of the "streets" to make them stand out more. Having completed the touchup process, we sealed the floor with watered-down satin sealer to protect the treatment and give it a slight sheen. The completed floor treatment is shown in Figures 65 and 66. 


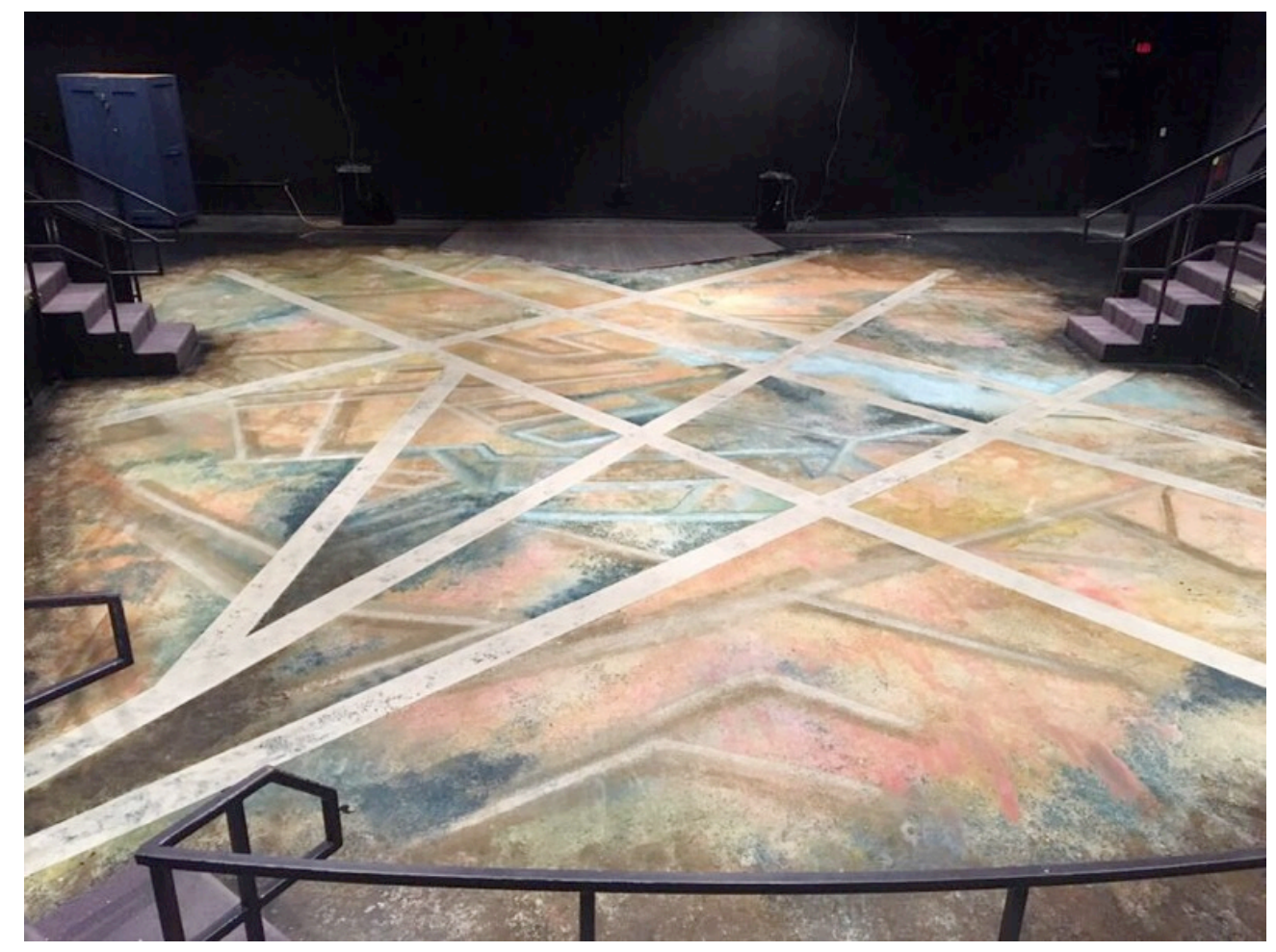

Figure 65: Front View of the Completed Floor Treatment

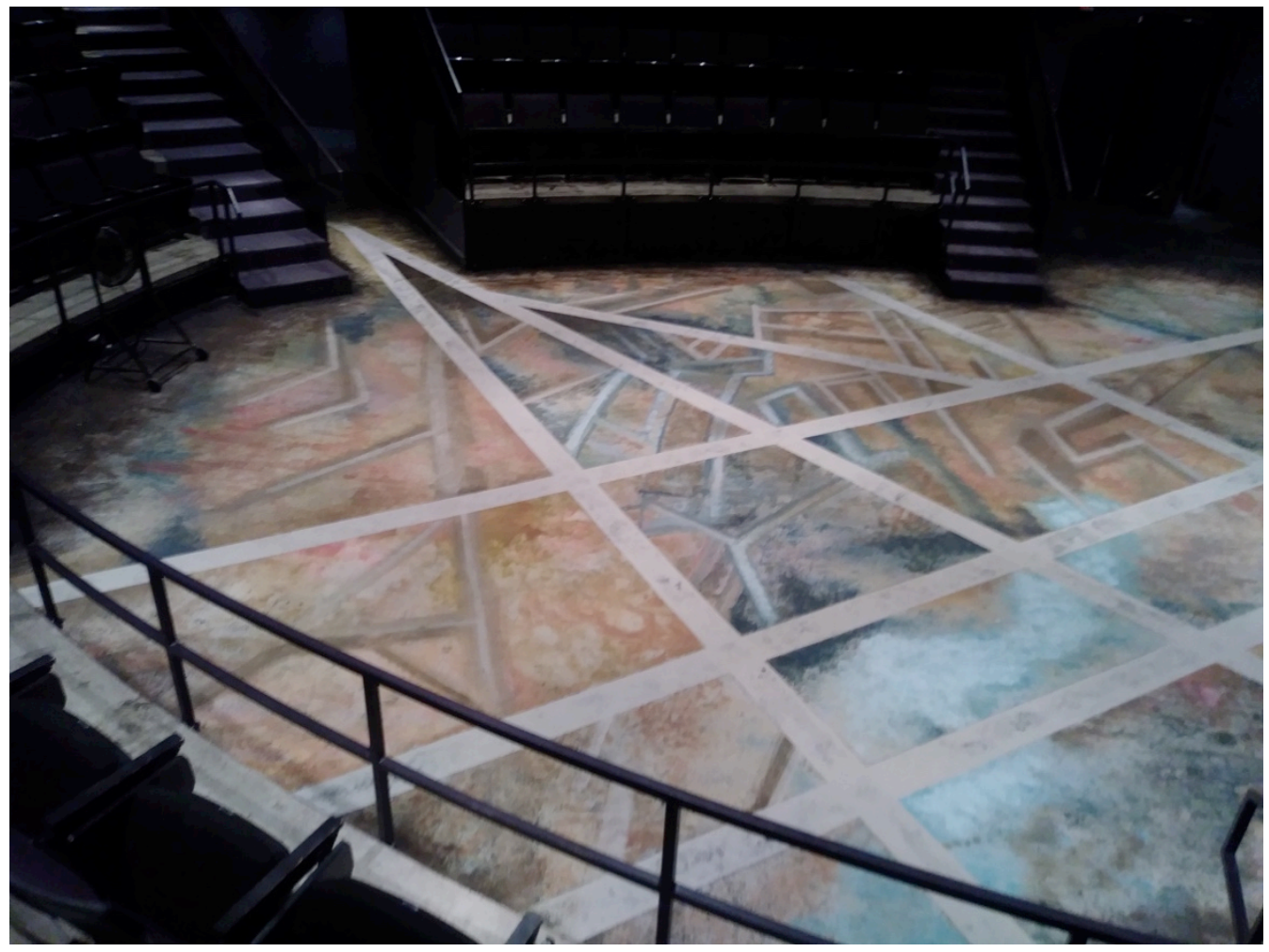

Figure 66: Stage Left View of the Completed Floor Treatment 
It was a triumphant feeling to leave the theatre on Sunday while it was still light outside, when we had originally anticipated having to work well into the night. The set could now be loaded into the space, and we did not have to worry about scrambling to paint the floor while working around a crew loading-in.

\section{Constructing \& Painting the Wagons}

When Skiba returned, he continued working on the wagons in the shop, which turned out to be a more complicated and lengthy process than we had expected. It is typical for the technical director to perform a "test-fit" of large scenic units in the scene shop prior to the official scheduled load-in of the set in the venue. This is to ensure that large pieces have been assembled safely and correctly before we allow the actors to utilize them during rehearsal.

Skiba had to construct both wagons by creating a skeleton of welded steel to ensure that the wagons would be strong enough to support active fight choreography. The steel was later hidden by pieces of MDF that would receive stylized paint treatments (Figures 67-69). I had designed the wagons at dimensions too large to fit into the Davis theatre through our scene shop load doors, which meant that Skiba had to completely assemble both wagons in the shop first, both for the purpose of the test fit and the scenic art processes, then break down both painted wagons to load them into the space in pieces, and then completely reassemble them in the Davis theatre. 


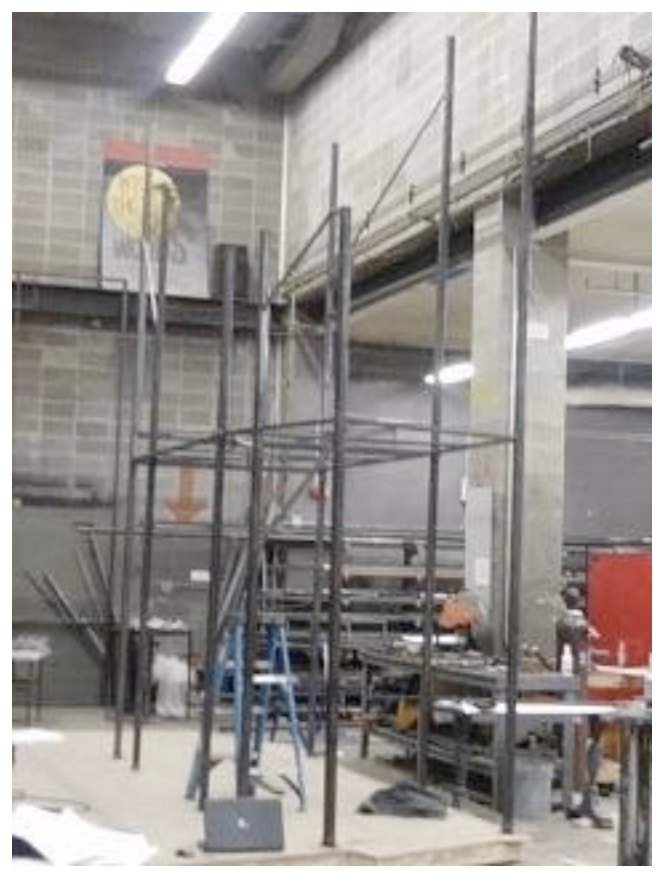

Figure 67: Inner Steel Frame of the Stage Right Wagon

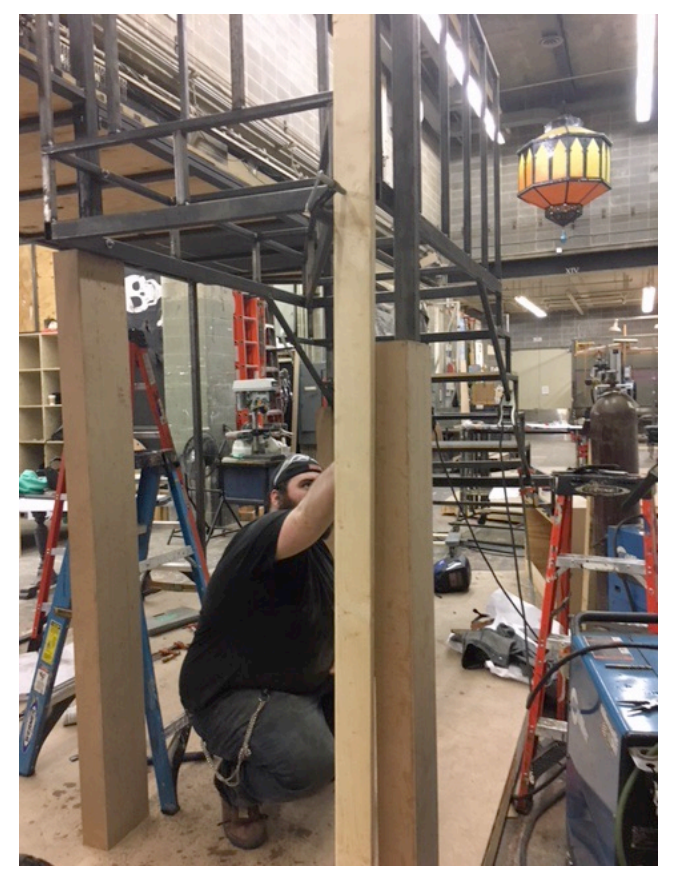

Figure 68: Skiba Covering the Steel Frame with MDF

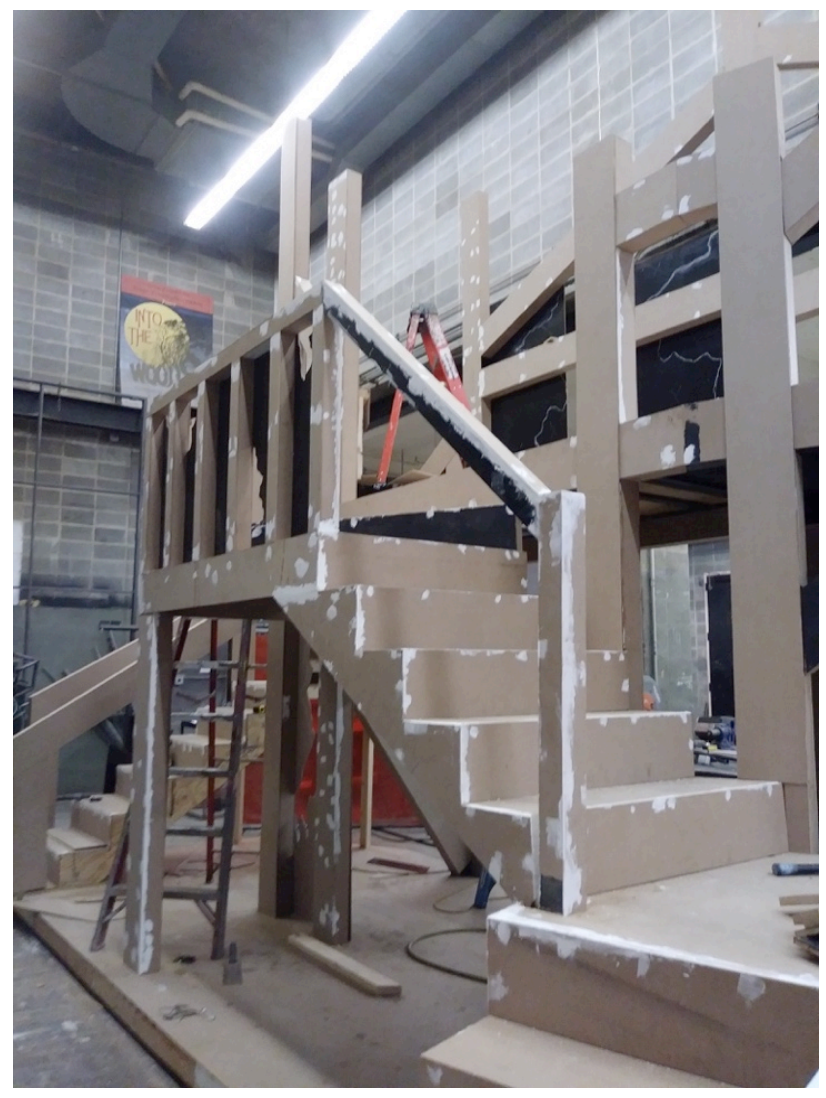

Figure 69: The Stage Right Wagon Completely Faced with MDF 
Skiba realized too late that he had made an error during the test-fit that pushed the build behind schedule: he had constructed the stage right wagon first at the far end of our shop, and constructed the stage left wagon afterwards, when this should have been done in the opposite order. This is because with the way our shop is laid out in relation to the load door of the theatre, it was required that the stage left wagon be loaded in to the space first. If he had completed the stage left wagon first, Raymond and I could have completed the paint treatments on the wagon as he built the stage right wagon. Once the painting was completed, Skiba could have started breaking the stage left wagon down and installed it in the theater as Raymond and I painted the stage right wagon, and we would have been more on schedule with load-in. Figure 70 shows the construction of the stage left wagon.

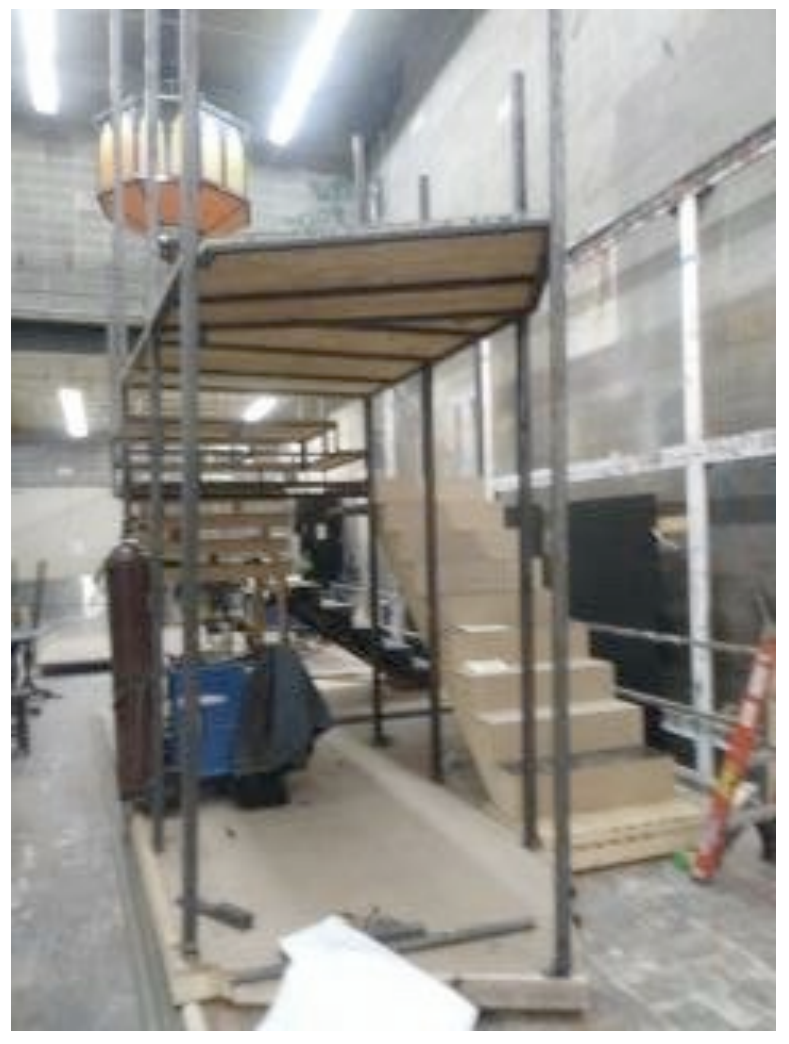

Figure 70: Construction of the Stage Left Wagon 
The scenic art processes for the wagon ended up being much quicker than I had expected, so we kept moving along at a really good pace. As we were about to start the treatment on the test-fitted stage right wagon, Professor Klingelhoefer approached me and suggested that I scrape a mixture of joint compound (JC), glue, and water onto the timber pieces to help give the beams a more realistic texture. I was originally only planning on applying a heavier version of this texture paste to the "broken" infill pieces between the timbers, but Professor Klingelhoefer convinced me that adding texture to the timbers themselves would elevate its appearance under stage lighting. He told us it would not add too much time to our process, so we took his advice and applied texture to the entire wagon, as shown in Figures 71 and 72.

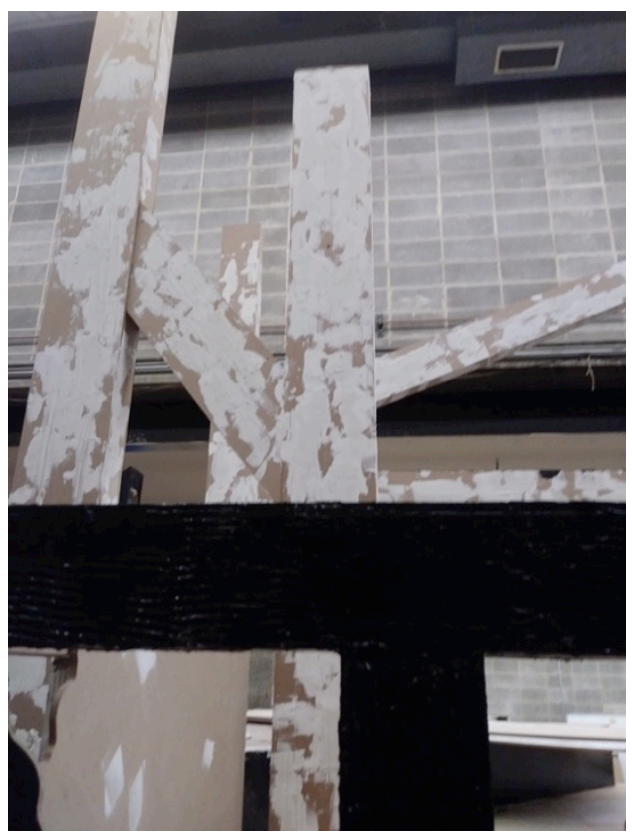

Figure 71: The JC Texture on the Stage Right Wagon Timbers

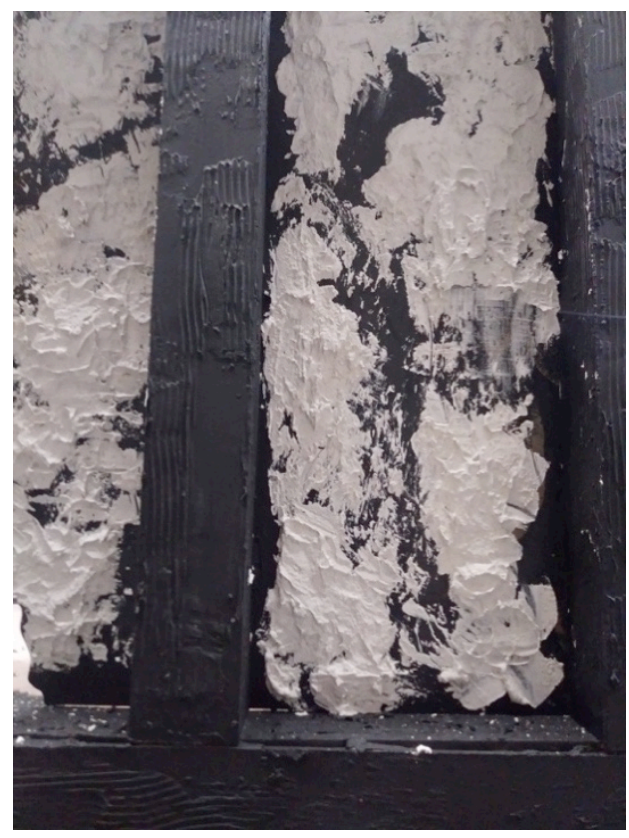

Figure 72: The JC Texture on the Balcony Infill

Professor Neuenschwander, Skiba's mentor, approached us and expressed concern that the load-in was already going to fall behind schedule and he knew the texture pastes would 
have to completely dry before we could paint them, but we assured him that we believed the texture was worth the extra time and we would still complete the treatment on the wagon before we could even begin on the stage left wagon. Fortunately, we were correct. We had finished the stage right wagon entirely and still had to wait a few more days before Skiba was even ready for us to begin painting the stage left wagon. Figures 73 and 74 depict the scenic art process on the stage right wagon.

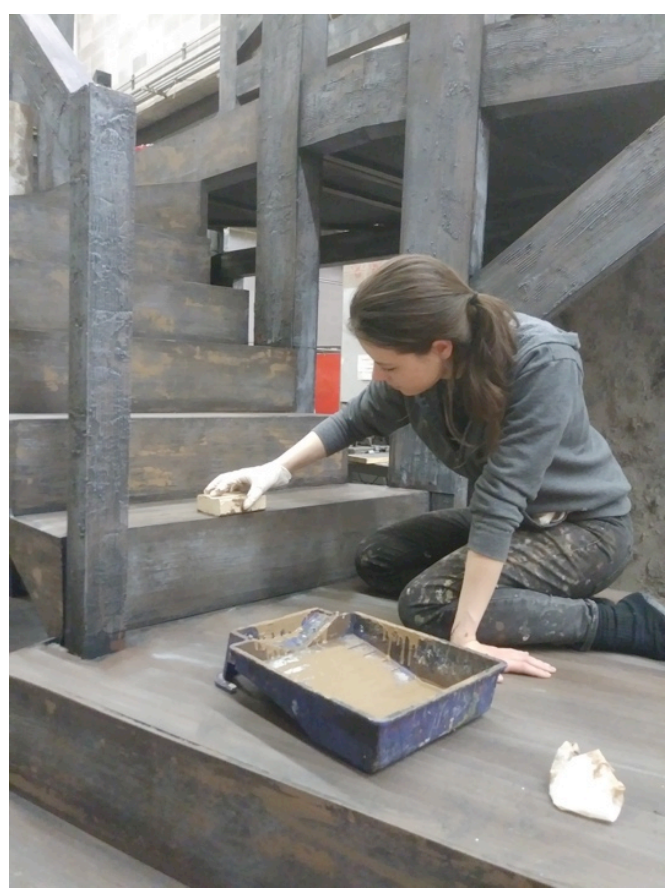

Figure 73: Painting the Stage Right Wagon

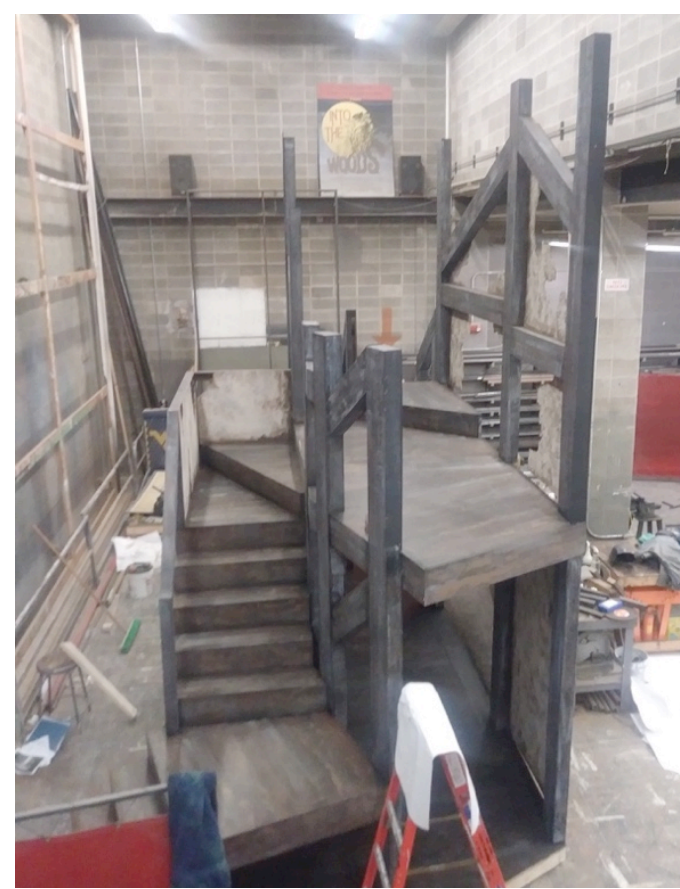

Figure 74: Scenic Art on the Stage Right Wagon Completed

Skiba was still working on the stage left wagon by the time the Easter holiday weekend rolled around and he formally scheduled a Saturday work call during that weekend in hopes that we would receive more help to get the build back on schedule. Unfortunately, we did not receive the help that we hoped for and desperately needed. The stage manager and assistant stage manager for the show came in to help, and although they were inexperienced builders, 
we greatly appreciated the gesture, and they were still able to help Skiba install certain pieces onto the wagon. Other than that, no one else came in to the shop all weekend. Raymond was unable to help because he had to travel during that time for an outside job. I also kept reminding Skiba that even though my own building skills are basic, I could still lend a hand if need be, but he encouraged me to instead focus on painting the several pieces of furniture included as part of the set design (approximately eight stools, one chair, three tables and a desk) so that the scenic art process would not also fall behind. All of the furniture in Figures 75 and 76 received varying types of wood grain paint treatments.

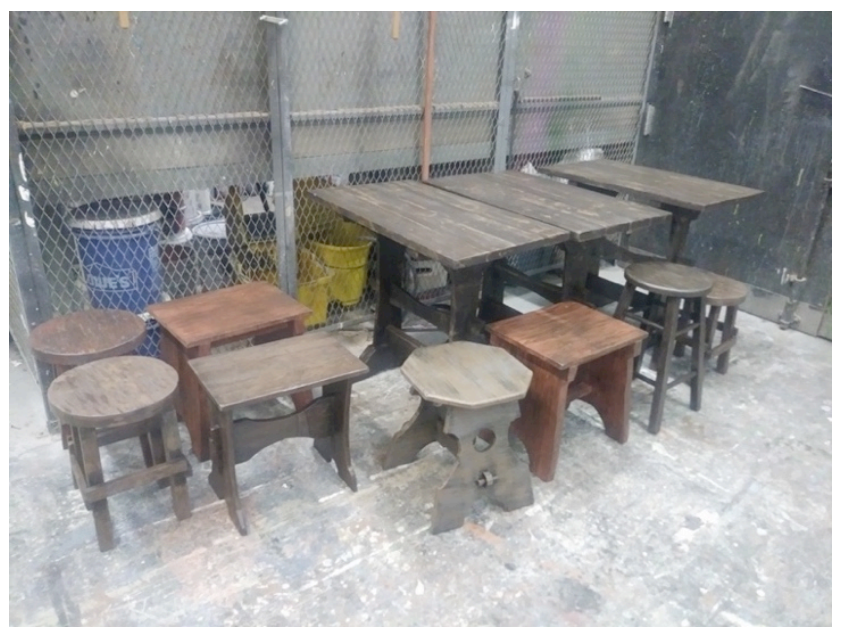

Figure 75: The Painted Tavern Furniture

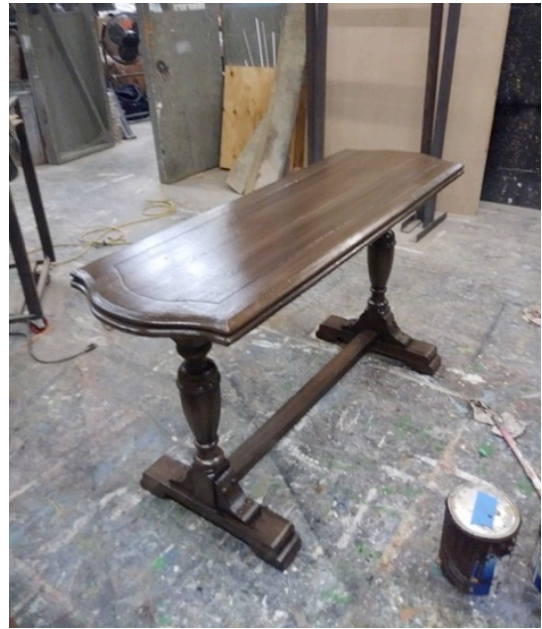

Figure 76: The Painted Desk for Treville's Headquarters

I was able to get all of the furniture painting out of the way during the first part of the weekend and began texturing and basing the stage left wagon by the time school had started again. Raymond returned, and similar to the stage right wagon, we were able to complete the entire paint treatment on the stage left wagon in under two days. Figures 77 and 78 depict the scenic art process on the stage left wagon. 


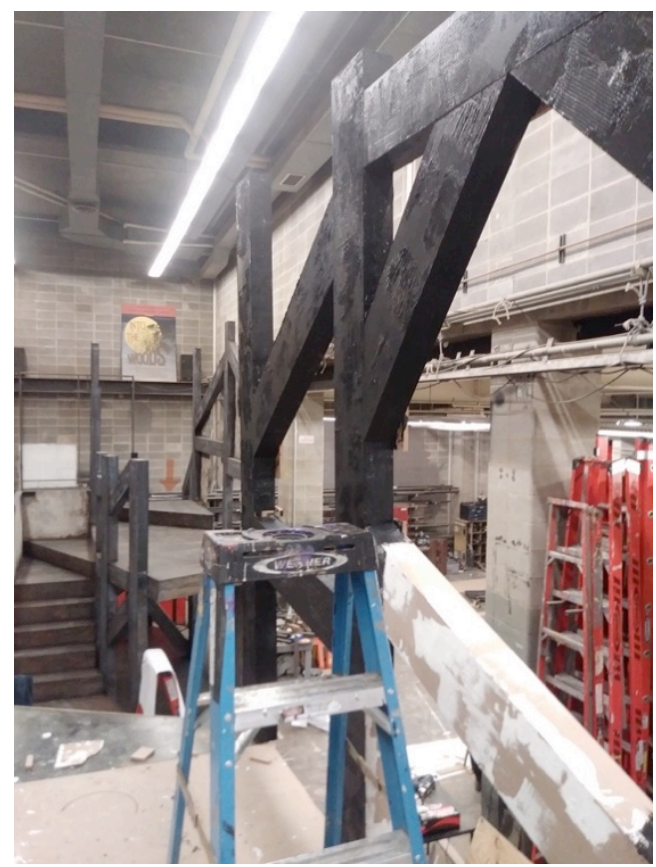

Figure 77: JC Texture Applied to the Stage Left Wagon

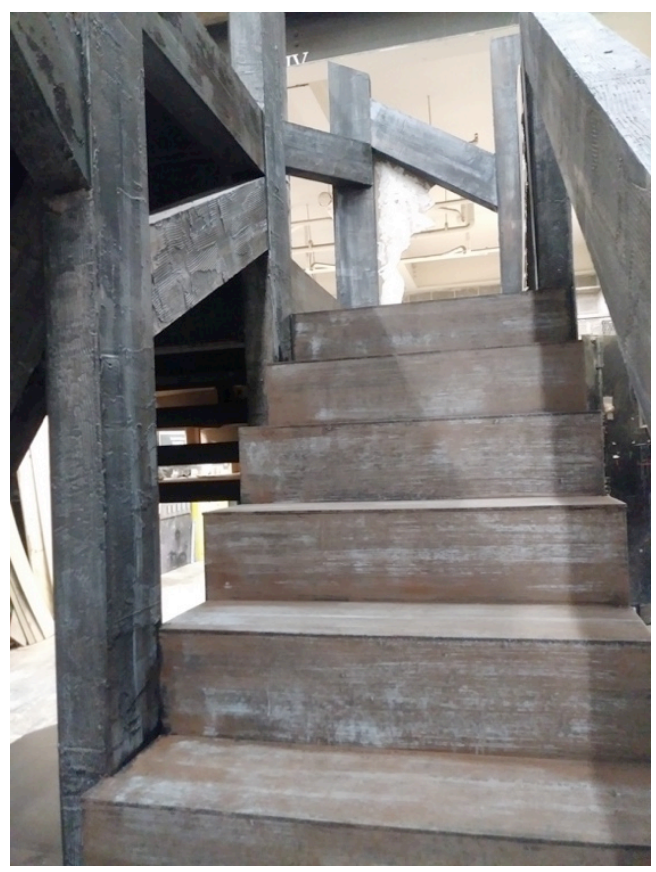

Figure 78: Painted Detail on the Stage Left Wagon

The painted wagons were disassembled and moved into the Davis theatre, where we started piecing them back together like a puzzle under Skiba's instruction. Breaking them apart into pieces inevitably meant that some of the paint treatment would be chipped away, but it did not take long at all for Raymond and I to touch up any areas that looked rough. Figures 79 and 80 show the wagons being rebuilt around the stepped pyramid platform in the theatre during the load-in process. 


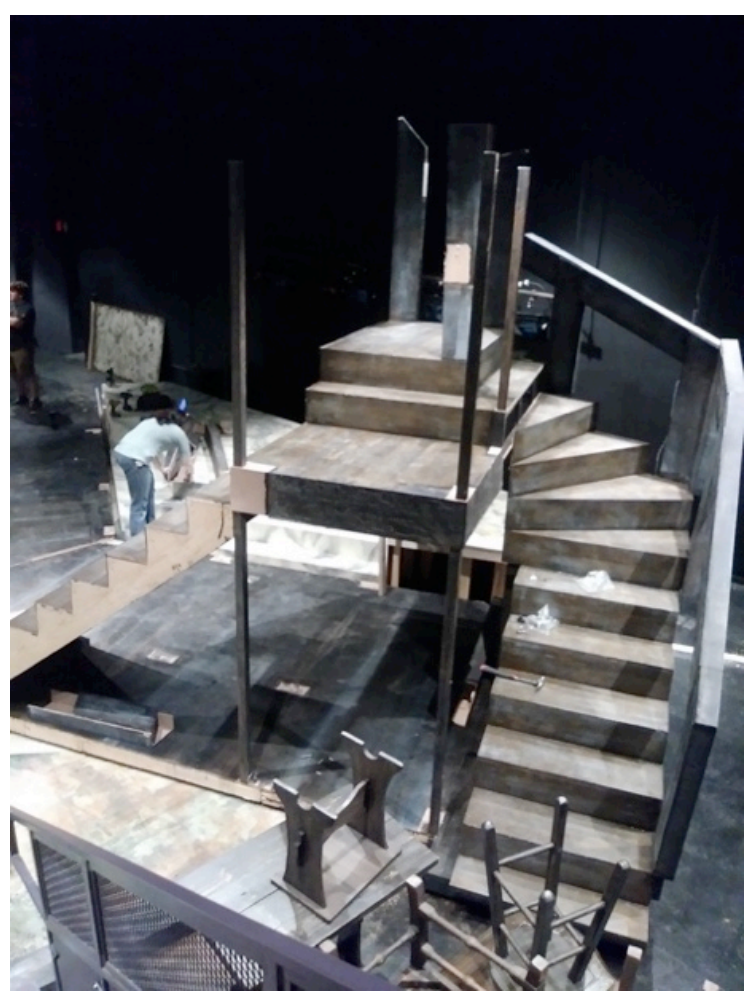

Figure 79: Reassembling the Stage Left Wagon in the Davis Theatre

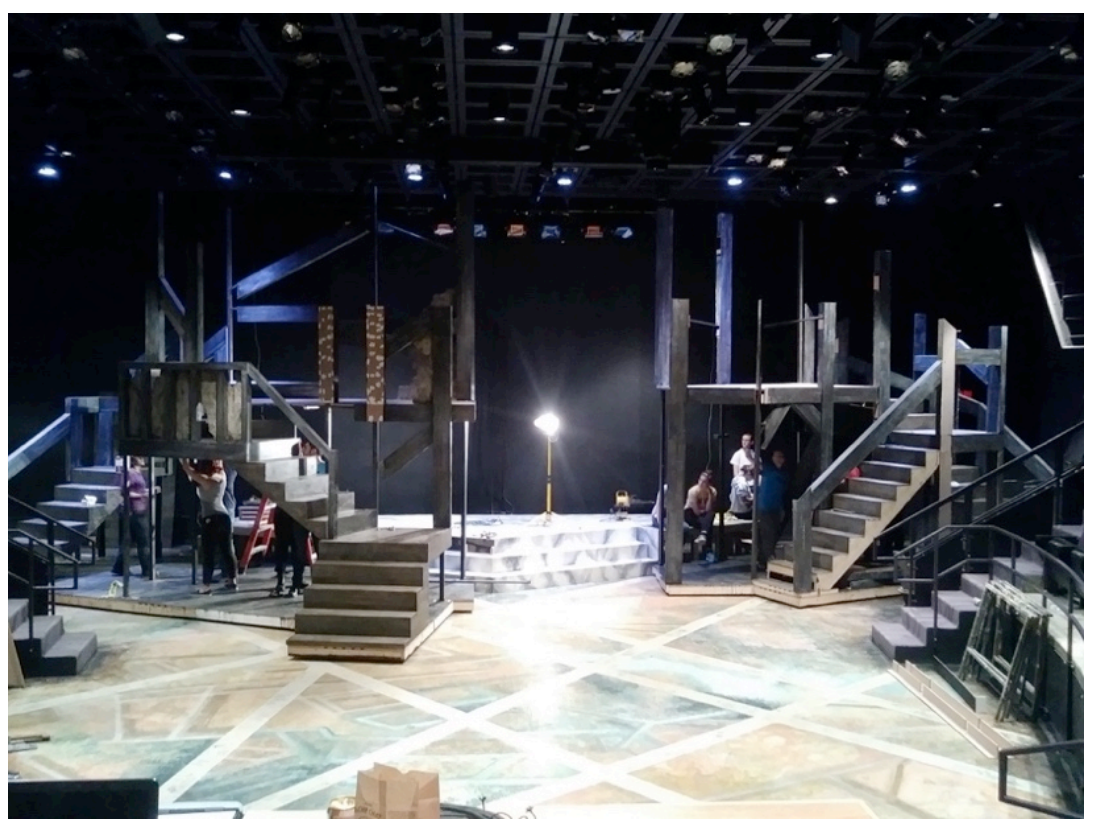

Figure 80: Both Wagons Partially Reassembled in the Davis Theatre 
The wagons were completely reassembled and safe for the actors to use just as tech week started. I recall being in the theatre when the director and his cast were shown the wagons in the space for the first time and felt slightly worried because I could feel how apprehensive everyone seemed. Up until this time, they had been rehearsing their fight choreography on a flat floor, and now with the new structures in place, they only had a few days to learn to safely incorporate large moving set pieces into their routine. Even though they could visually access and see the scale model in rehearsals, it was surprising for them to see the size of the set in the space in real life.

\section{The Technical Rehearsal Process}

"Tech Week" is comprised of the technical rehearsals and dress rehearsals that take place in the final week before a show opens. Tech week is a time for the actors to become accustomed to all of the scenery and props (ideally they have already become accustomed to the scenery during load-in, but unfortunately this was not possible in this scenario), lighting and sound designers finalize their cues and effects, and scenic transitions are orchestrated.

This was an especially stressful time for me because we had to begin tech week with a major scenic component missing: The Magic Doors. Building the doors proved to be an extremely tricky endeavor all in itself. Skiba had initiated the build process on this piece very early on, but one of the student carpenters assigned this task took a medical leave before he finished the project. It was discovered one day during our afternoon lab that the student had not quite executed them properly - the angles of the doors were riddled with issues, including not being square. Earlier, Raymond and I attempted to fix the mistakes in the doors, but fixing each little mistake seemed to be making all of the other errors worse in an unfortunate domino 
effect. Skiba eventually made the decision that the doors would need to be completely rebuilt properly, but he had to turn his focus back to the wagons since load-in was approaching.

Not having the doors in the space was troubling for me as a scenic designer because I was still unable to see how the scenic components worked together in the space. I also knew the actors would have to get used to operating them properly during transitions. I had never been in this situation before and was fearful that eventually I might be asked to cut the doors from the design. Doing so would have made the rear projection screen and interior wall seem random and out of place with the rest of the design, and the doors were crucial in helping to differentiate locations throughout the fast-moving story. Thankfully, it did not come down to this.

Over the next few days, the doors were built and Raymond and I were able to complete the majority of the paint treatment relatively quickly. We had originally planned to paint all of the detail on the doors, including the gilded trim for the King's World, but that was impossible in the amount of time we had left. Professor Klingelhoefer helped us print out decals from the plotter, and we were able to paste on the gilded trim before the doors were installed in the set (Figure 81). The doors were laying flat on saw horses for this treatment because it would have been much more difficult to apply such dainty decals properly and symmetrically while standing upright. 


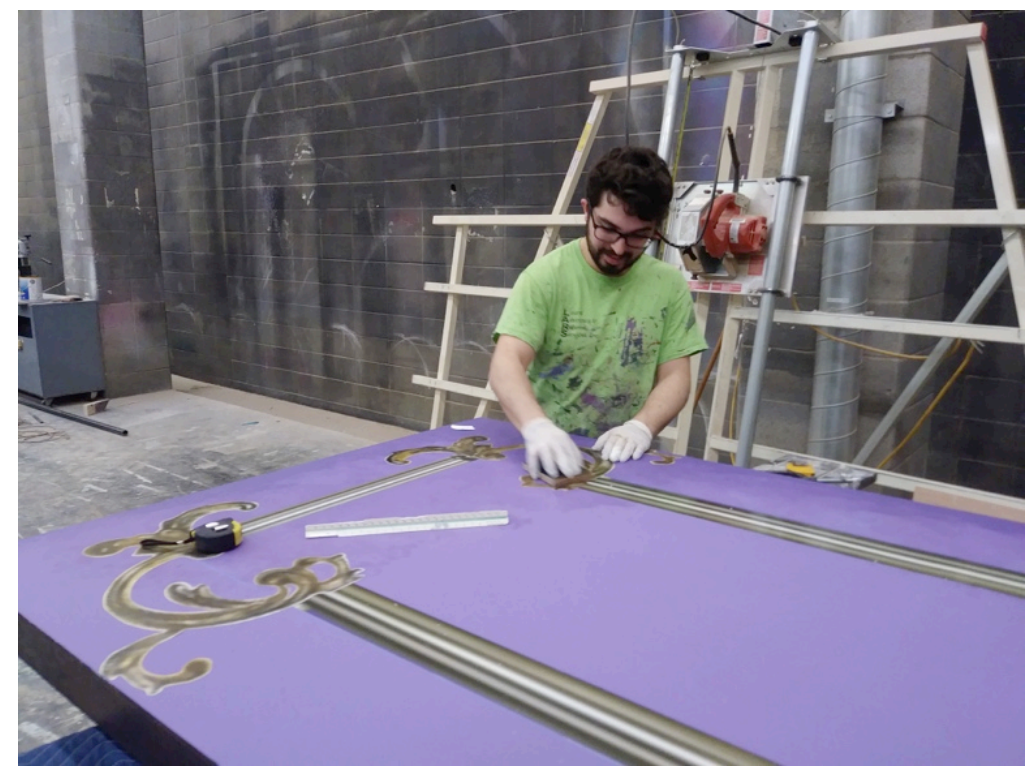

Figure 81: Raymond Applying the Gilded Trim Decals to the King's Doors

Finally, the doors were installed in place on the stepped pyramid platform, but Skiba and I were discouraged to find that our problems were not over. Once both doors were upright and their pipes were secured to the platform and the grid, he realized that he had accidentally built the doors with their pipe channels in the incorrect position. I had already known that the desired effect for unhinging the extra panels to create a straight line of four panels would only work if the pipes were in a very specific position because I had made a scale model mockup of the doors to ensure that the extra panels would open correctly before I drafted them. I had even made a note of caution regarding this in my designer drawings, which was most likely forgotten as we struggled with the building process. I do wish I had caught this mistake when he started to rebuild the doors, but I was preoccupied with other tasks.

Luckily, this error actually did end up working out in our favor. We realized that even though it was impossible to unfold the doors to create a straight horizontal line of panels, as I had originally intended, it was possible to arrange the unfolded doors into a " $\mathrm{V}$ " shape that ran 
parallel to the pointed angle of the stepped pyramid platform. This still achieved an interesting look for the King's ball, and I actually liked that the doors were not in a straight horizontal line. The only downfall of this arrangement was that the front faces of the edges of the two doors that pointed downstage did not meet up perfectly, which meant that splitting one large Sun King decal onto the two doors would look odd because the image would not match up. To rectify the problem, I decided to print two full smaller Sun King images, one for each center door. While this was not the exact look I had hoped for, I was still glad that we were able to salvage the effect of unhinging the doors for the King's ball scene.

The doors also did not operate smoothly when they were first installed, but eventually the actors became accustomed to operating them correctly during the scenic transitions.

Raymond and I eventually applied the remaining decals on the doors throughout the rest of the week. The remaining hurdles during this process included color issues and improper placement of the decals. The images I had chosen for the "Neutral" brown doors were not printing in the correct shade of brown. At first I tried applying brown floral spray, but this just made the color look even more out of place. I had also accidentally glued the decals for the tops of the doors upside-down at first and hated how they looked. The problems were solved by scraping off and replacing those upside-down decals with a newly printed set in a brown tone that looked better against the paint treatment on the doors.

\section{The Chandeliers for the King's Ball}

After the doors were completely affixed, the very last element of the set that remained was the pair of chandeliers I had borrowed for the King's ball scene. By this point in the 
process, we had segued out of tech rehearsals into dress rehearsals, and opening night was quickly approaching.

Gillette approached me in the shop and mentioned that since the chandeliers had yet to be installed, it was too late for him to incorporate or rearrange his cues in the ball scene to account for those pieces. I was a little taken aback by this encounter because the chandeliers had been a consistent element of the overall design since the very beginning and were present in both the renderings and the drafts the entire time. In fact, I had not yet had a chance to discuss the chandelier situation with the Technical Director, so I found Skiba in the shop and asked him what his plan was regarding the installation. He seemed confused as to why I asked him and assured me that it was the very next thing he was planning to do, as it was the very last item on his punch list. I described the brief discussion with Gillette, and his response was that he planned on helping me completely realize my design. I made sure to let him know that I knew we were running out of time, and I made sure he understood that if he thought he would be unable to rig them up in the time we had left, I would be completely understanding. He told me that he appreciated my concern but that he really wanted to try because that was the very last element left to fully realize the design after all the hurdles we had overcome.

This issue was brought up in our tech notes meeting following the rehearsal that night, and Skiba reiterated that he wanted to try to install the chandeliers. I immensely appreciated his drive and determination to finish the whole project, but knew in the back of my mind that he most likely would not have enough time to pull this off. The next morning, Skiba apologetically admitted that the rigging process was too much for him to take on that late in 
the game, and I reassured him that I was totally supportive of his decision. Other than that, all of the elements of the set were finally in place and the show was ready to open. 


\section{Part IV. Conclusion}

\section{Production Analysis}

Overall, I felt that the production was relatively cohesive in terms of concept and design, though not as cohesive as it could have been.

After the design deadline, it seemed for a little while as though Professor Gabara's overall interpretation of the script was veering away from the appearance and vibe of a Disney action/adventure film, and resemble more of a comic Mel Brooks film instead. As rehearsals progressed, notes began to appear in rehearsal reports such as requests for the musketeers to enter Constance's death scene wearing rollerblades, and he had mentioned that he wanted to spoof our department's previous production of Assassins. The latter effect would have been achieved by dressing Rochefort in a Santa Claus-inspired robe for one scene, since the actor playing Rochefort had played the Santa costume-wearing character, Samuel Byck, in Assassins. However, both of these ideas ended up getting dismissed, so in the end I did not have to worry about rollerblades or Santa robes clashing against the scenery. He did spoof our department's previous production of Three Sisters (the actors playing the musketeers were all in that cast) by utilizing props and a sound effect of honking geese from that show, incorporating them in the "serious" scene in which Athos reveals his past with his ex-wife. As it turned out, these details ended up seeming more fitting onstage than I had imagined, so I did not feel that it disrupted the world we had created.

As I mentioned in my analysis of the script, I do want to reiterate that I believe the script was very poorly written, or at least not fit for a university-level production. While there were some directorial decisions made that I do not necessarily think were right for the story, I do 
have to say that I fully admire and respect the spirit behind Professor Gabara's ideas and decisions. He was given a poor script to work with and I admire his creative imagination and willingness to take risks in order to try to make the best of a challenging situation. There were several shows in which the audience was extremely responsive to the humor he incorporated in the show, such as the surprising dance number to "You Should Be Dancing" by the Bee Gees during the King's ball scene, or the unapologetically melodramatic acting in Constance's death scene, so for the most part, the show seemed to be received positively.

If the director had decided to push Mel Brooks-inspired humor even further in our overall interpretation and production concept from the very start of the process, my design most likely would have looked very different. I might have pushed the playground concept much further and actually made the set more reminiscent of a wooden castle-style playground, or I might have intentionally tried to mimic a poorly-designed Renaissance Faire with very artificial-looking facades and garish colors to contribute to a humorous look. There also might have been major intentional discrepancies between the period styles of the scenery and props to enhance the comedic effect.

Since some of Professor Gabara's extraneous ideas that seemed slightly unfitting for our production were either toned down or ultimately cut, I do think my actual design still ended up working well for the world of our show, and I felt that Professor Mary McClung's costume designs worked really well with the set. Her costumes were mostly period, but with playful touches; I especially loved watching King Louis's golden platform shoes walking against the colorful abstracted map floor treatment. 
However, I did not feel as though the set and lighting design worked together as cohesively. I have to admit that I was pretty disappointed with some of Gillette's lighting choices. Even back in early design meetings with the director, before the final design deadline, Professor Gabara stressed the importance of the Cardinal's World being color-coded as red, and I made a point to remain true to this in my final design presentation. In fact, the entire inspiration behind incorporating the rear projection screen in the set design was to enable the color red into any scenes that took place in Richelieu's chambers. I had noticed during tech rehearsals that the rear projection screen was only glowing a shade of blue when it was being utilized, so I asked Gillette if it was going to turn red for the Cardinal's World. Gillette even admitted to me right off the bat that Professor Gabara had apparently expressed the same concern, but his reasoning was that he could supposedly only choose one color to light the screen, so he chose blue. My assumption is that blue was chosen because it is typically a default choice to simulate daylight, but I still feel that he should have just chosen red. The rear projection screen even had a masking wall with trim on it to create the illusion that it was part of an interior wall-there was never any intention on my behalf for the screen to be treated as a sky. The screen was even lit with blue for Richelieu's scenes, in which the actor donned bright red robes and an exaggerated codpiece, which he was wearing due to Professor Gabara's infusion of overt sexual humor. Red is an obvious color choice to denote sexuality and/or kinkiness, so the blue screen clashed severely in these scenes, seeming to fight against both the costumes and set. In retrospect, I wish I had spent more time trying to convince Gillette to change the color to red, but it may have actually been too late at that point to make that change. 
Another unfortunate incident that occurred during the run of the show was that the actor playing d'Artagnan injured his foot during a fight call. As a result, he not only had to wear a boot cast, which did not fit in with his costume and all of his other designed surroundings, but it also forced the fight choreography of his final fight with Rochefort to be adjusted to take place entirely on the thrust theatre floor. The final fight was intended to be the most climactic fight of the show, and the choreography originally took place all over both of the wagons, which were designed to directly support that possibility. Following his injury, the wagons did not seem to be used by the actors as much during the show since many of the earlier fights in the show also took place on the stage floor. The earlier fights on the stage floor were still entertaining to watch and included humorous usage of tavern stools and other props, but prior to this occurrence, they also helped the last fight on the wagons seem more intense and serious by comparison. This accident happened about halfway through the run of the show. Having been an audience member both pre-accident and post-accident, it reaffirmed to me how essential the wagons I had designed had been to that moment. When the fight was moved to the floor, the most important fight of the show seemed somewhat anticlimactic.

Looking back, I really wish that there were not so many events scheduled at the same time that we were trying to build the set, and Skiba also admitted to me that some of his build drawings were not completed on time, which contributed to some of the complications and hold-up in the building process. I was extremely thankful that throughout the entire tech week process, Professor Gabara was nothing but patient, kind, and polite to the entire design/technical team. I would not have blamed him had he been stressed, especially since The Magic Doors were not installed at the beginning of tech week, which was a major hindrance in 
rehearsals. If he was stressed, he never took it out on any of us. I am whole-heartedly grateful for how understanding and respectful he was to his team because it brought an air of calm and hope to a very stressful situation.

In retrospect, I still cannot believe that the entire set (minus the King's chandeliers) made it into the space before opening night, and that the actors and crew adapted to their scenic transitions in such a short amount of time. After the show opened and closed, I remember thinking "If that show could actually come together, I can make it through anything." Ever since, I have learned to try even harder to have faith in the whole process, because in the end, things usually do, somehow, come together and work out. 


\section{Appendix A: Production Photographs}

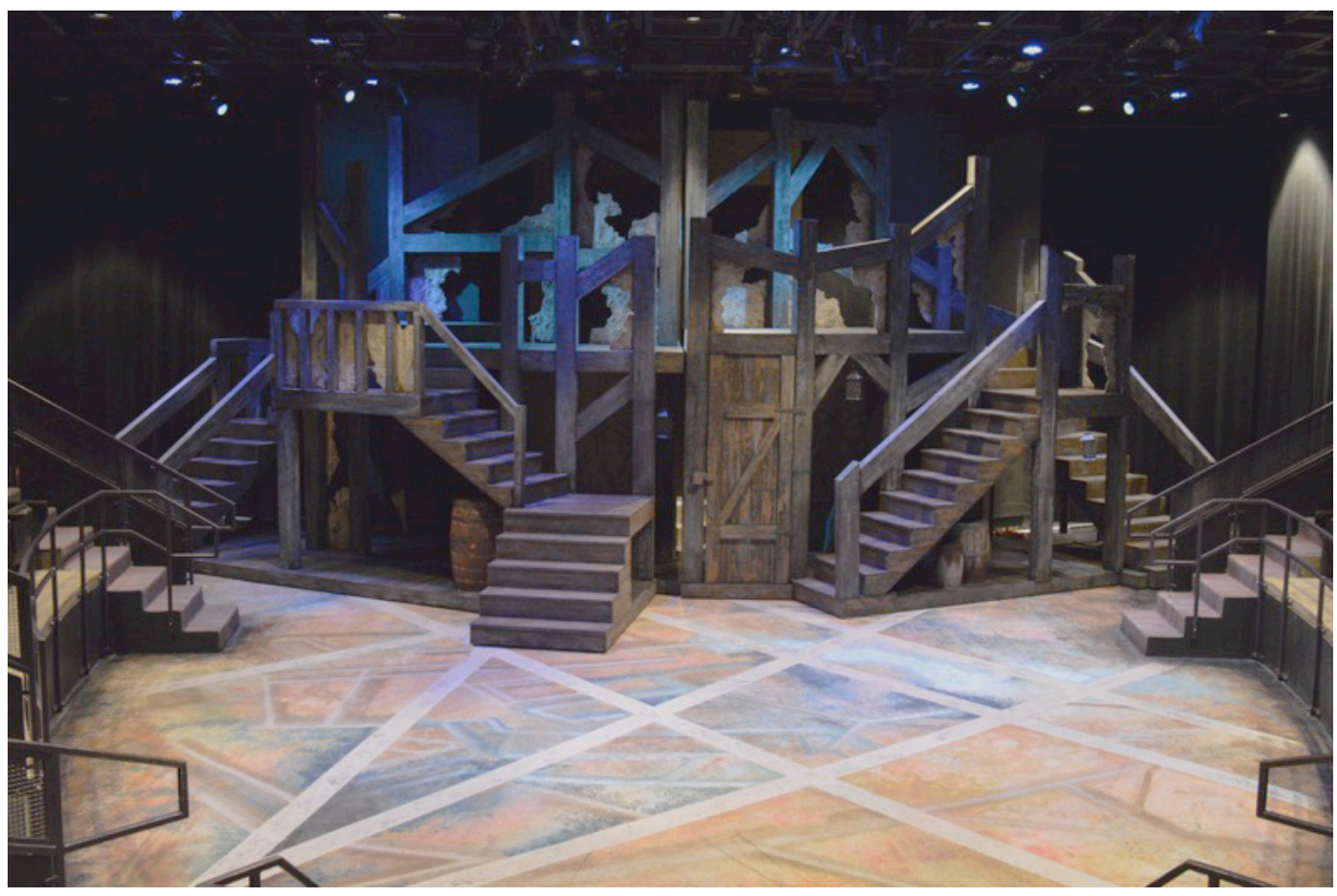

The Completed Set, Front View

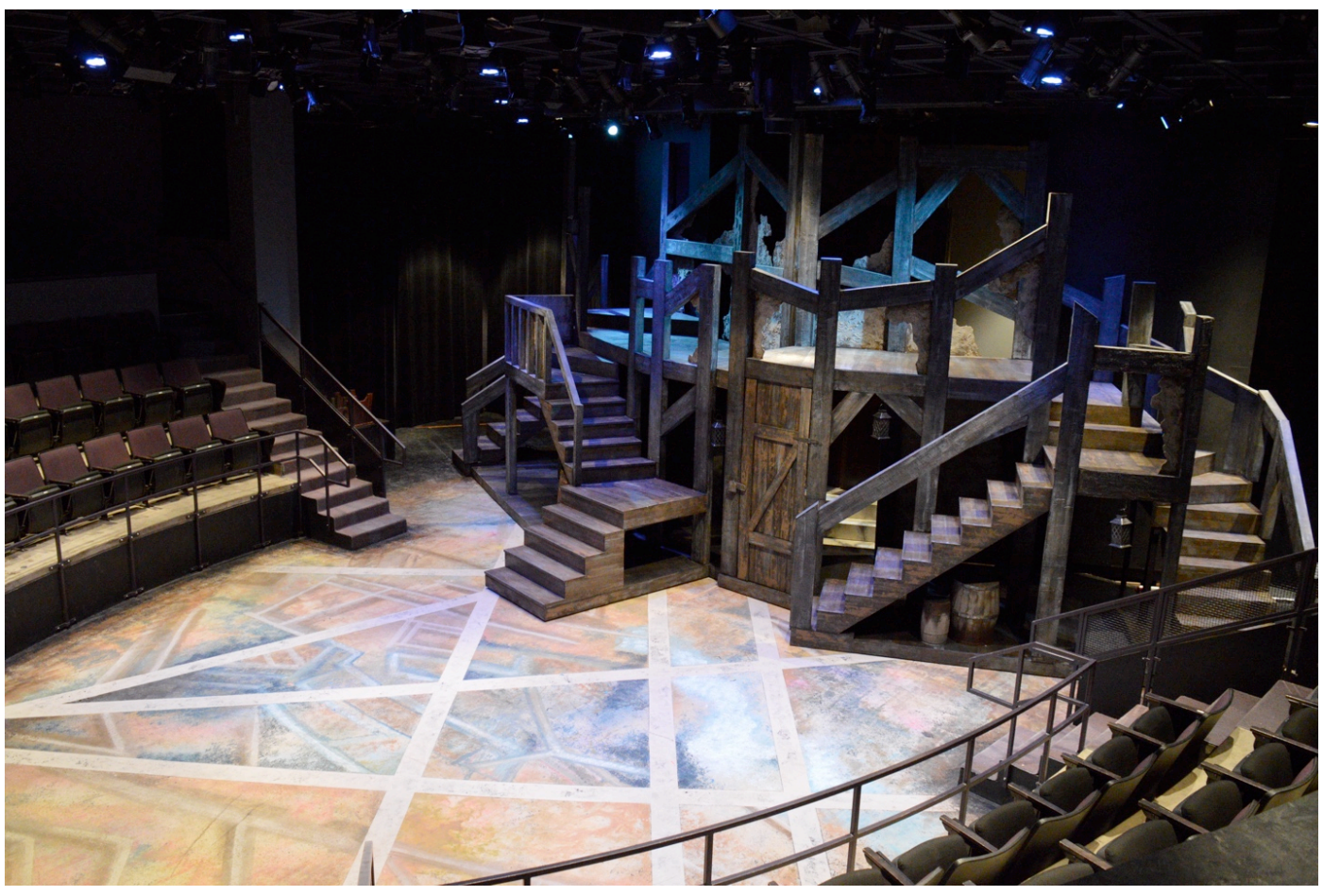

The Completed Set, Stage Left View 


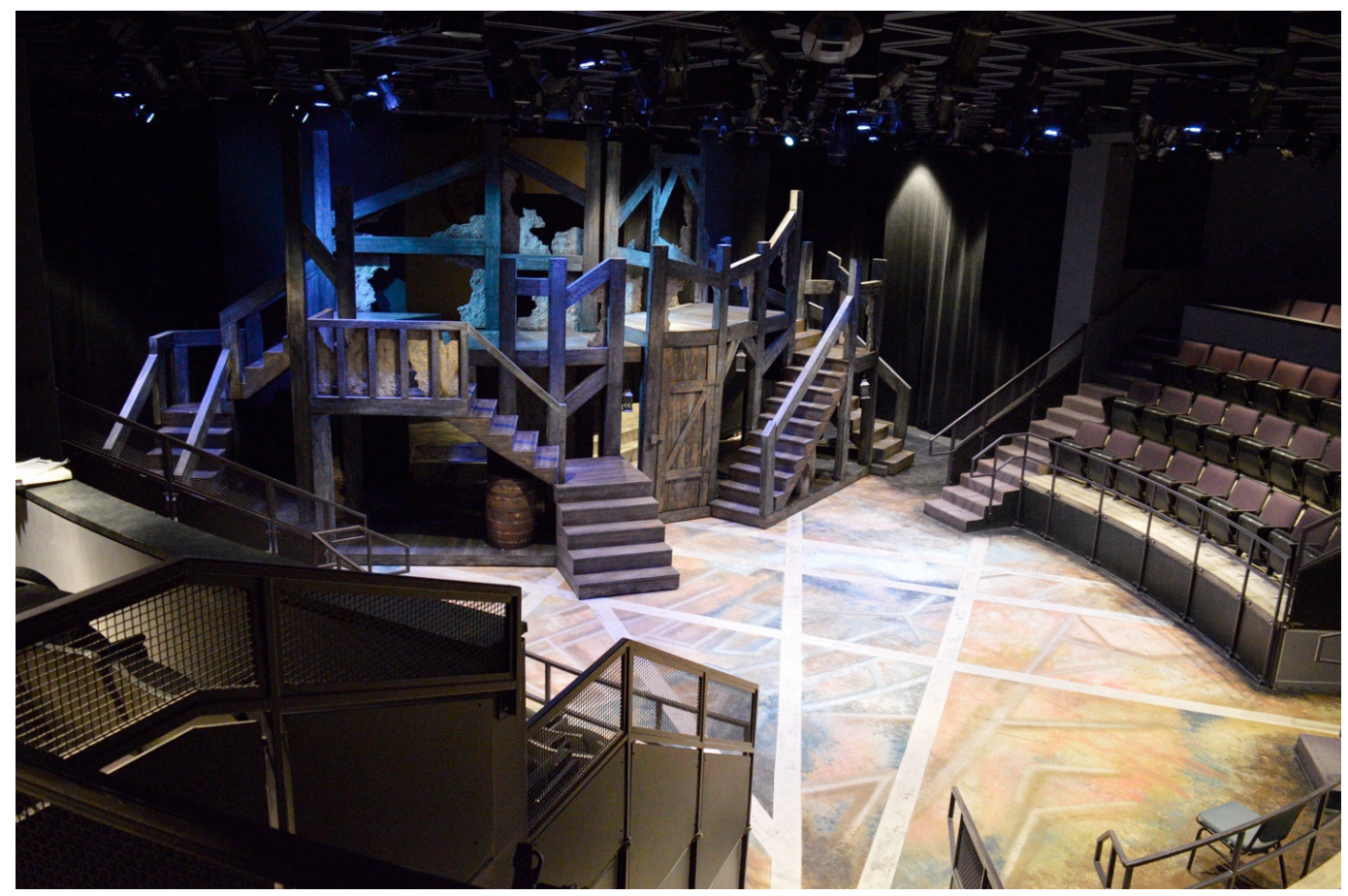

The Completed Set, Stage Right View

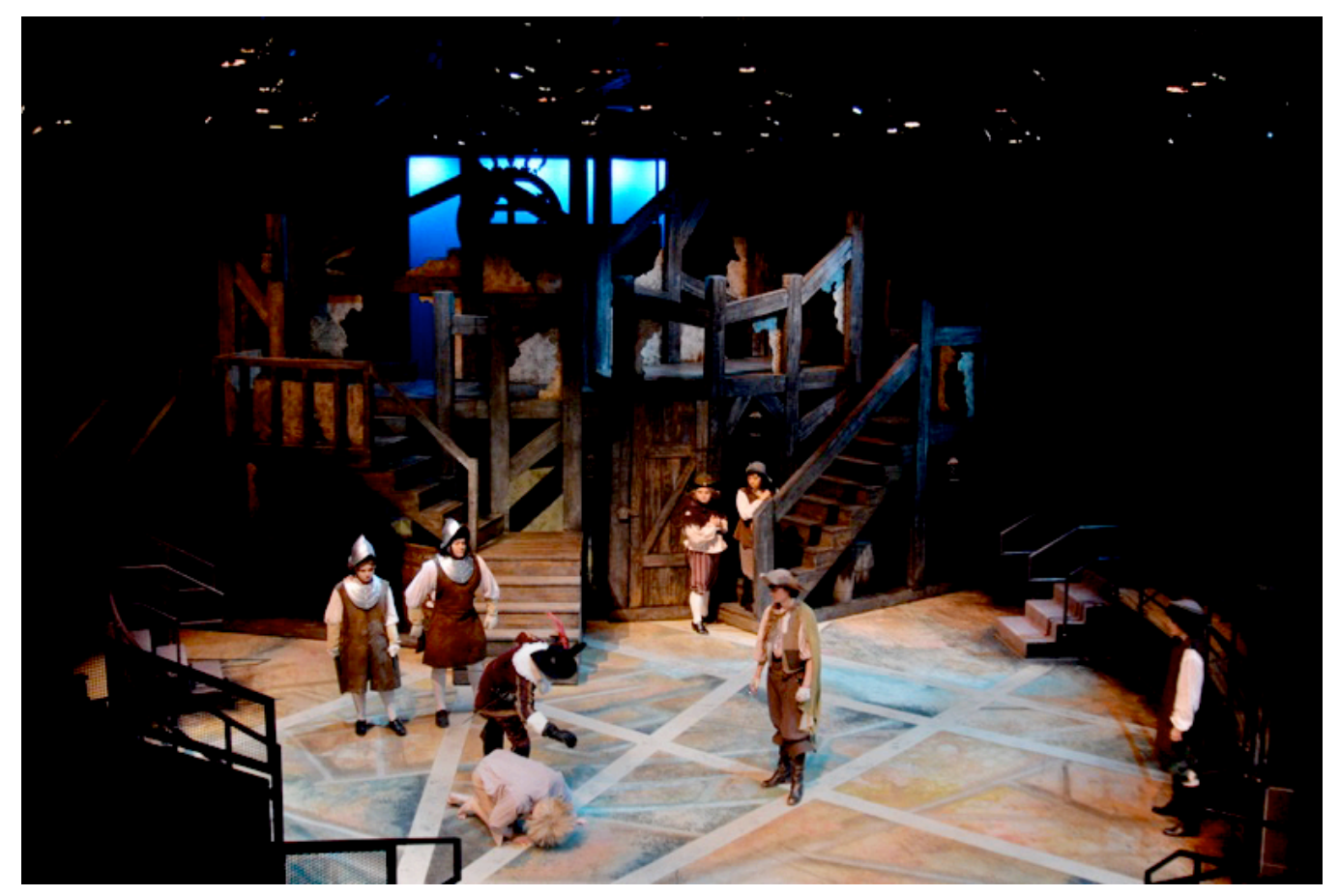

Act 1, Scene 1: D'Artagnan's First Encounter with Rochefort 


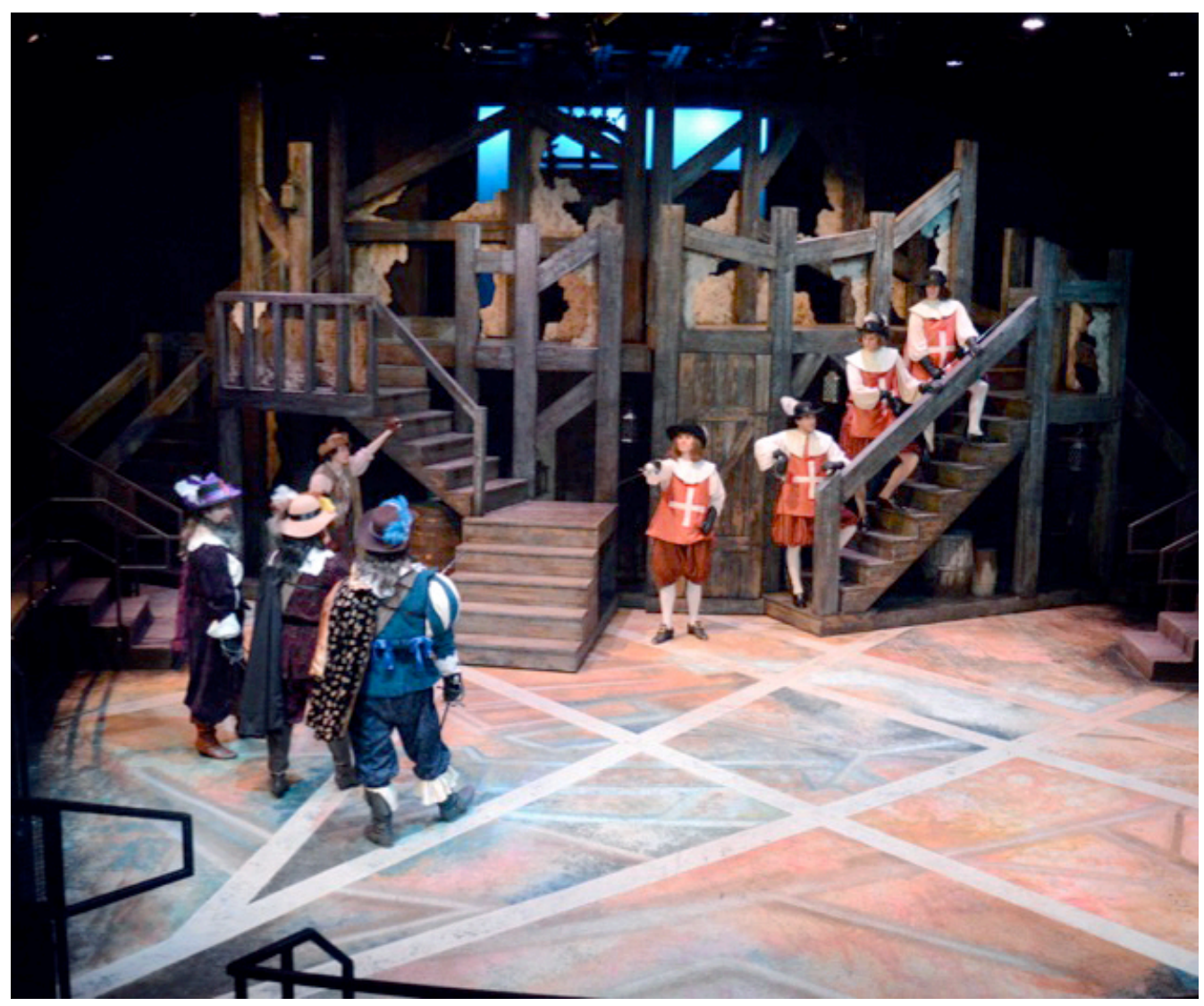

Act 1, Scene 3: Jussac and His Guards Threaten to Arrest the Musketeers

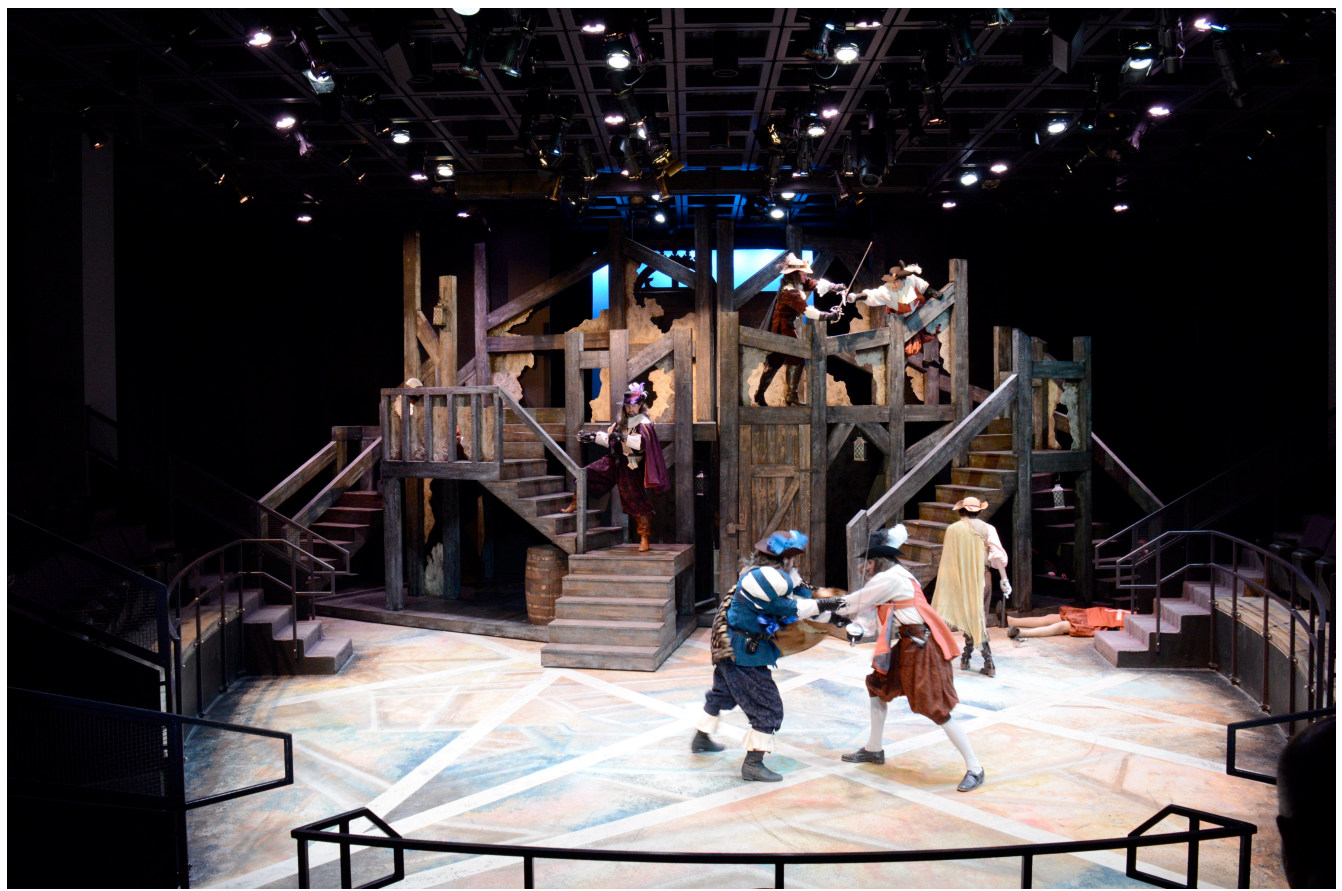

Act 1, Scene 3: D'Artagnan Fights the Cardinal's Guards Alongside the Musketeers 


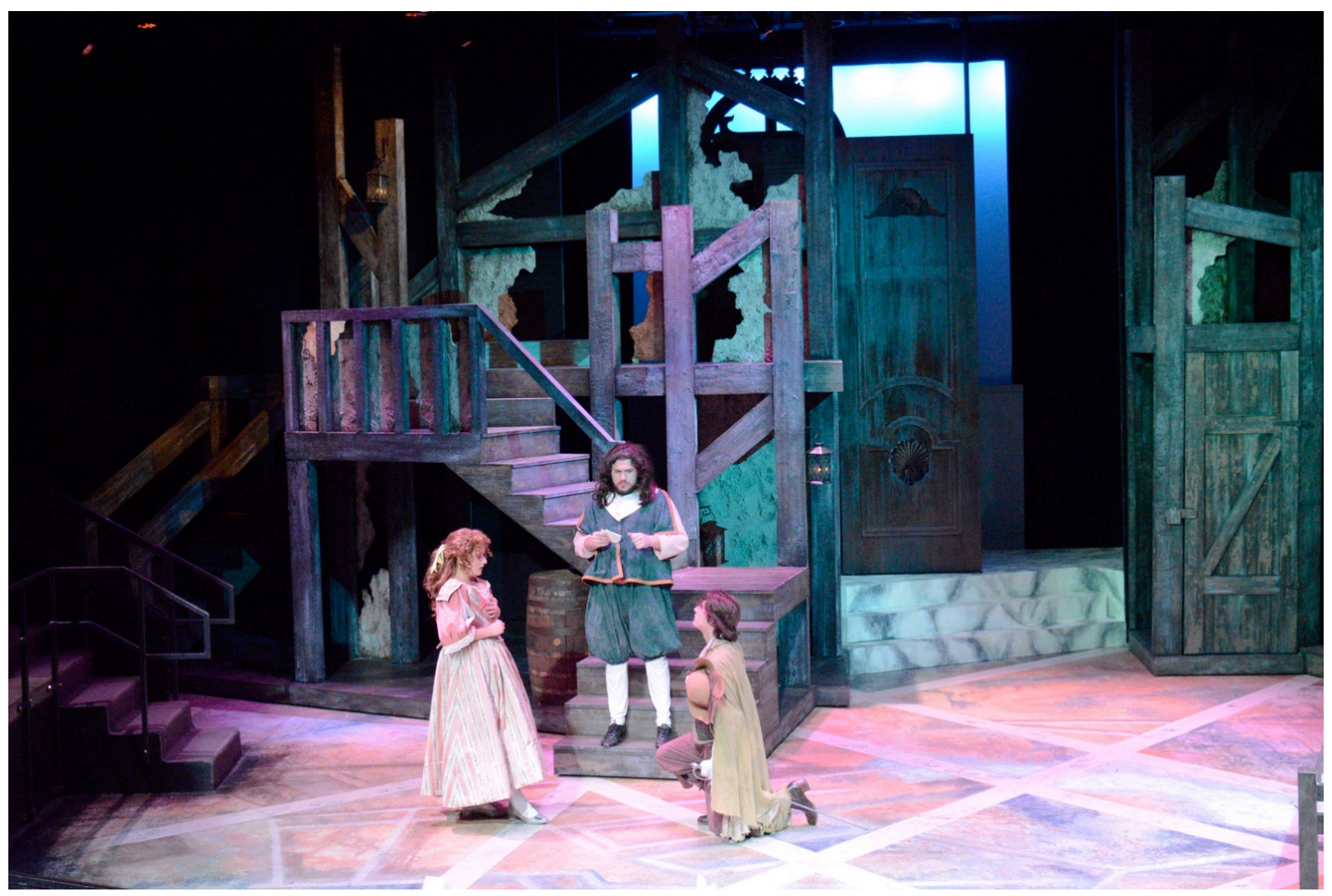

Act 1, Scene 4: D’Artagnan Falls in Love with Constance at First Sight

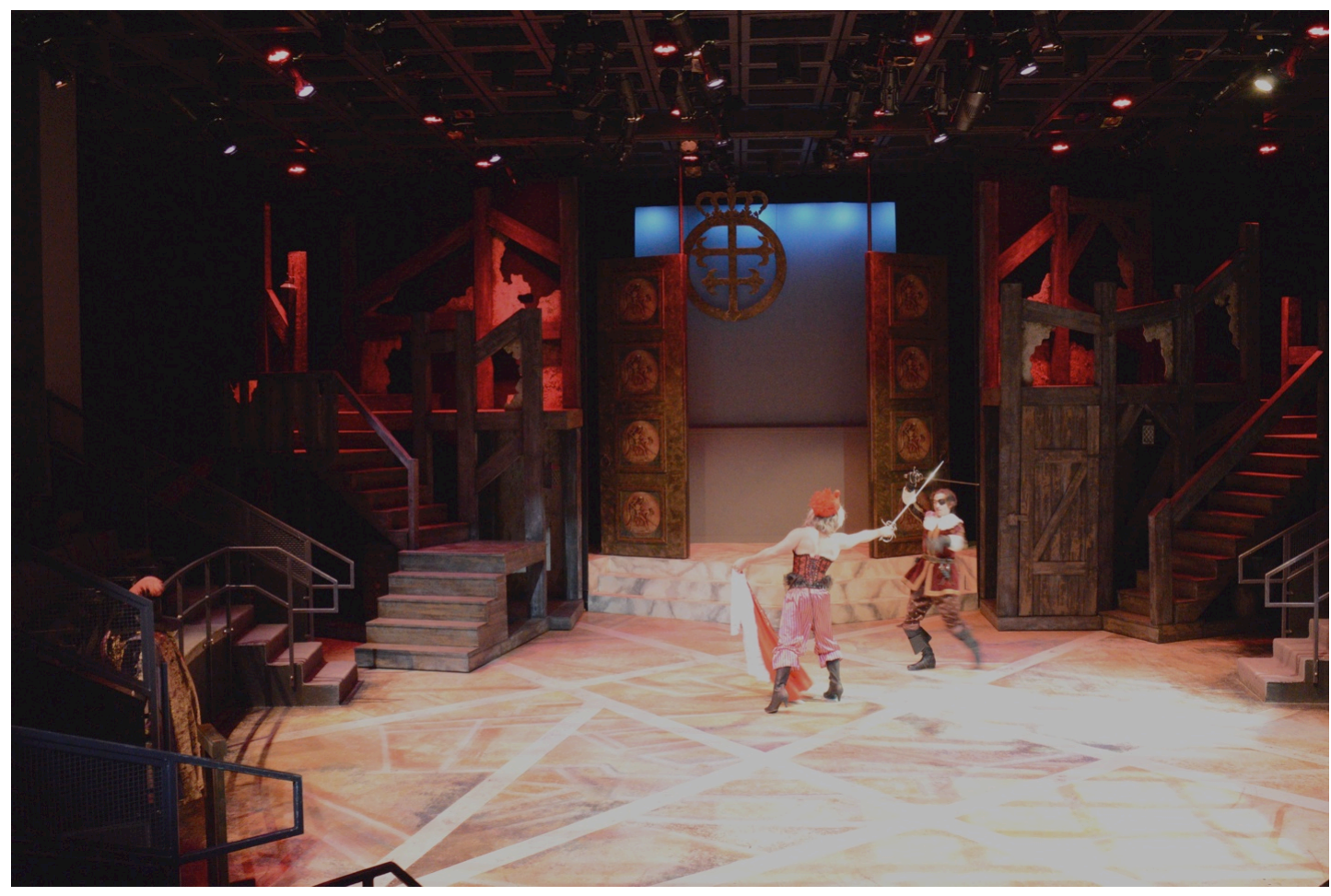

Act 1, Scene 6: Richelieu and Rochefort Practicing Their Swordplay in the Cardinal's Chambers 


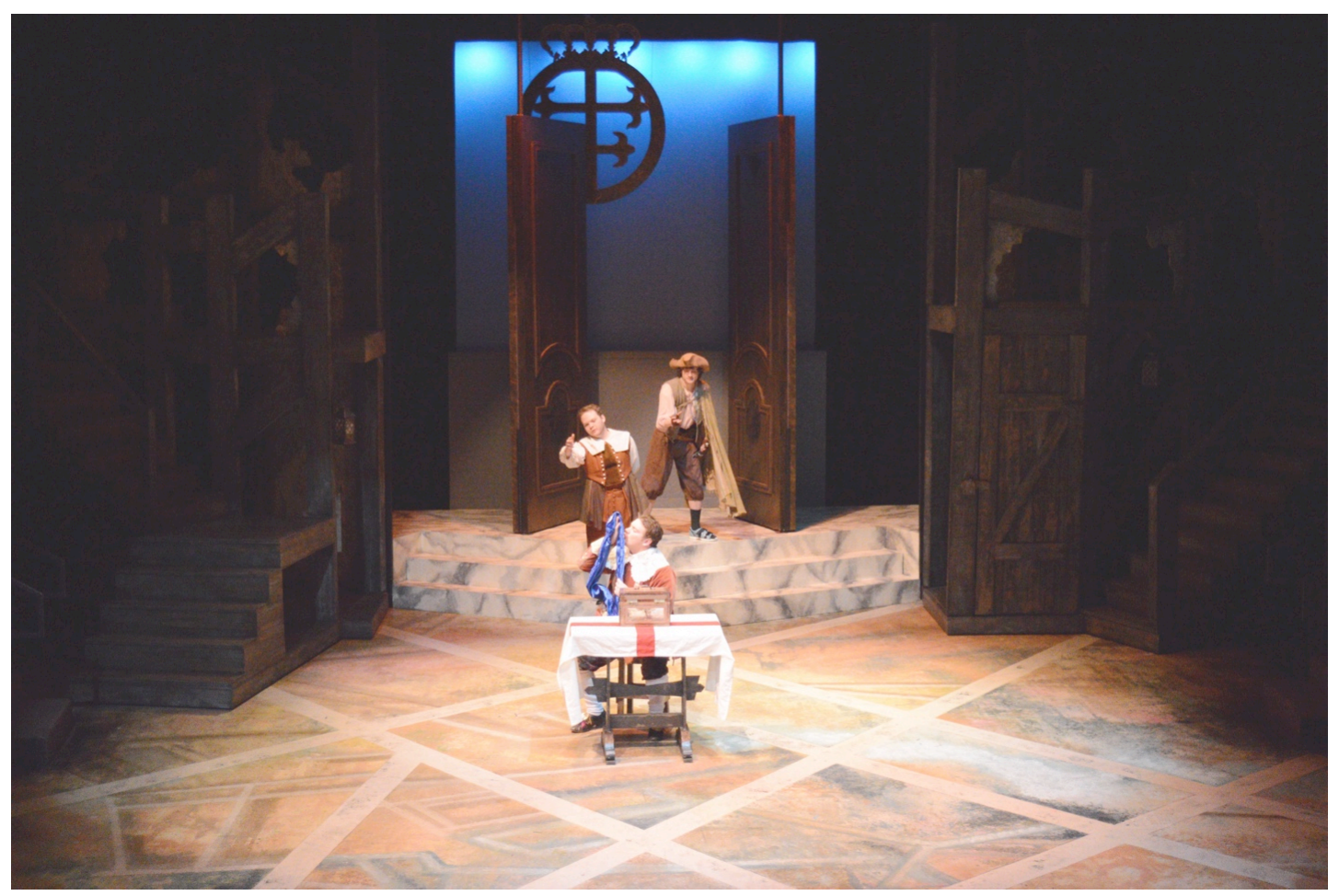

Act 1, Scene 9: D'Artagnan Arrives in London to Retrieve the Queen's Diamond Sash

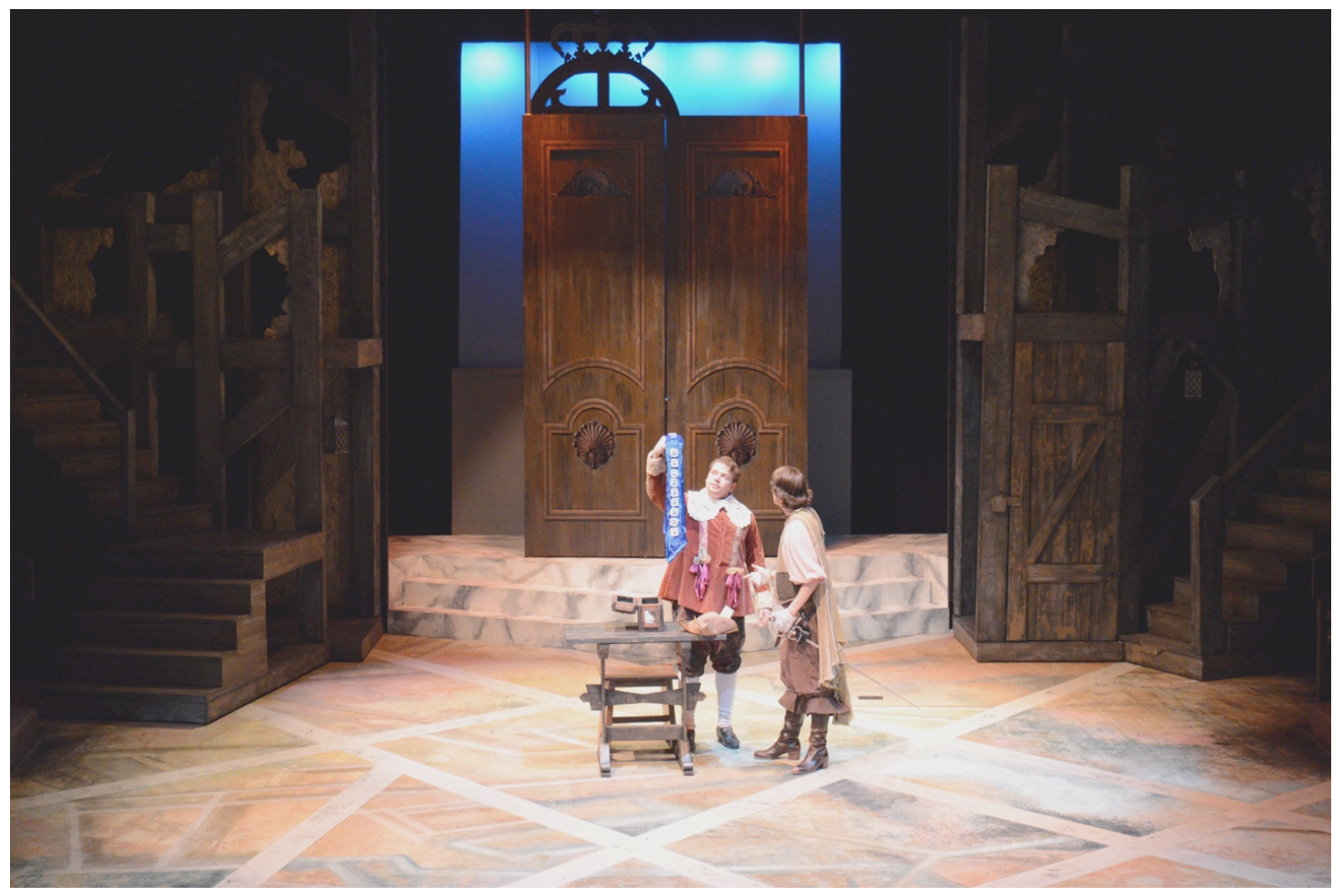

Act 1, Scene 9: Buckingham and D'Artagnan Realize That the Sash is Missing Two Diamonds 


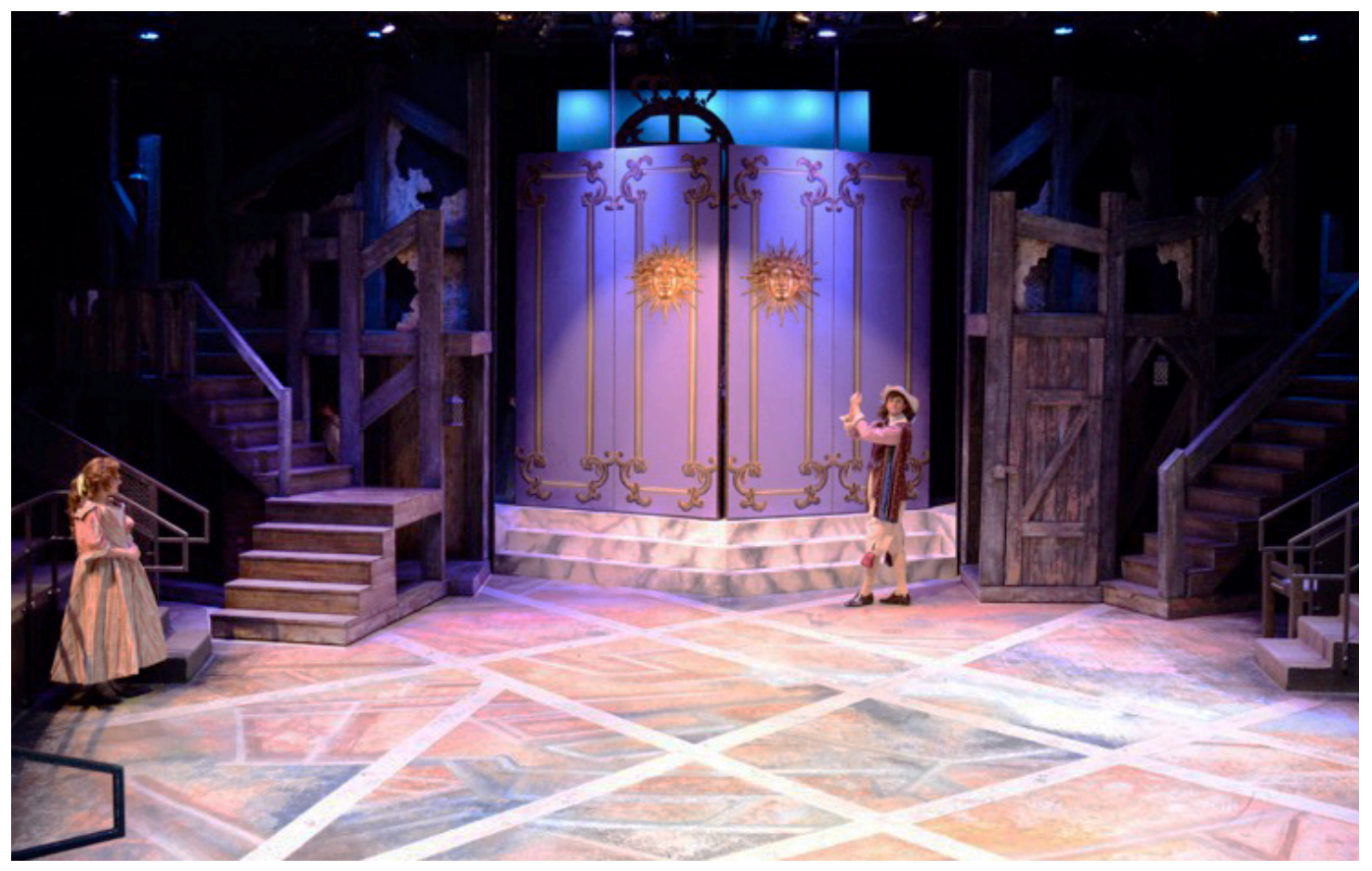

Act 1, Scene 10: Setting Up For the King's Ball

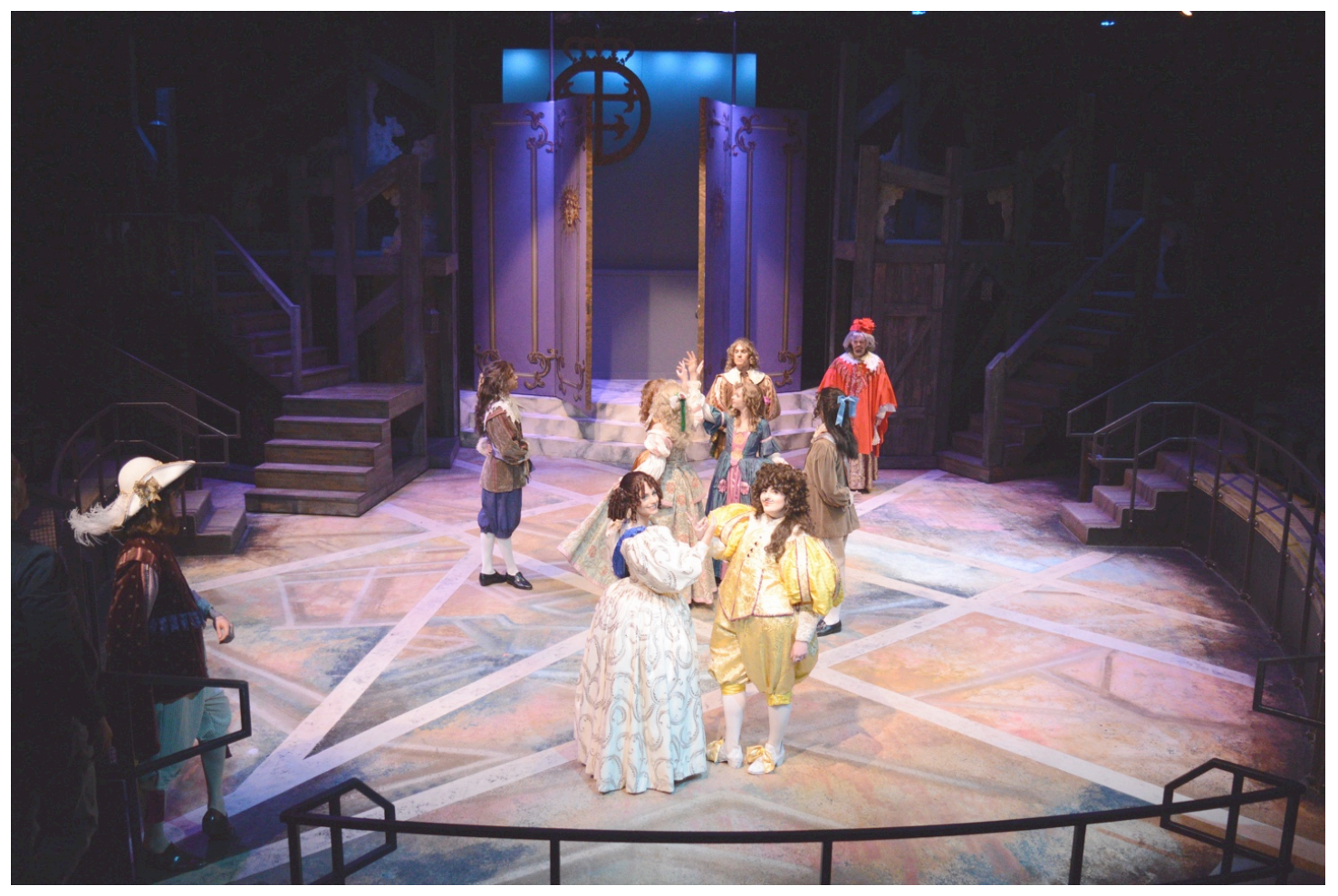

Act 1, Scene 10: The Ball Has Begun 


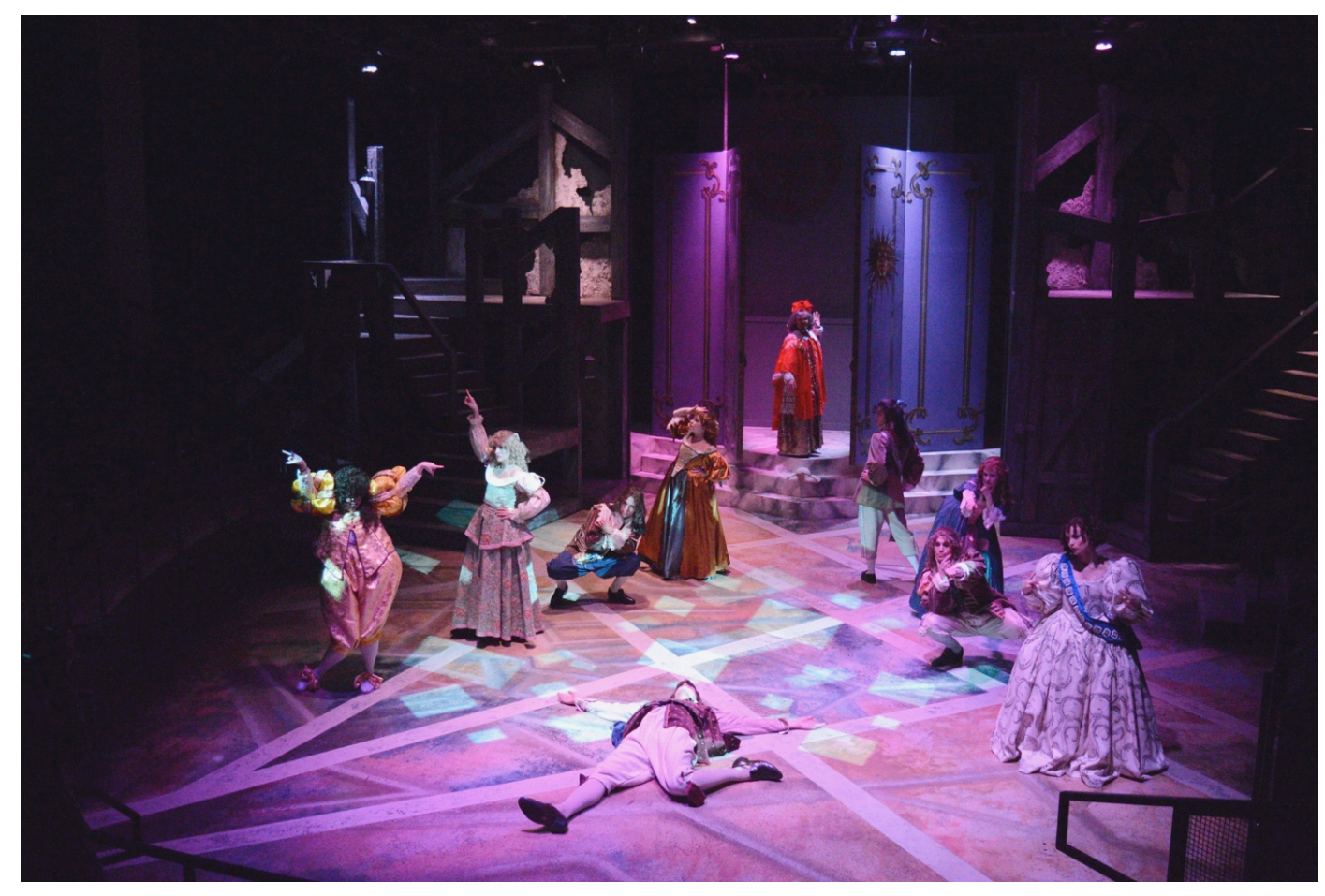

Act 1, Scene 10: The Surprising "You Should Be Dancing" Dance Break

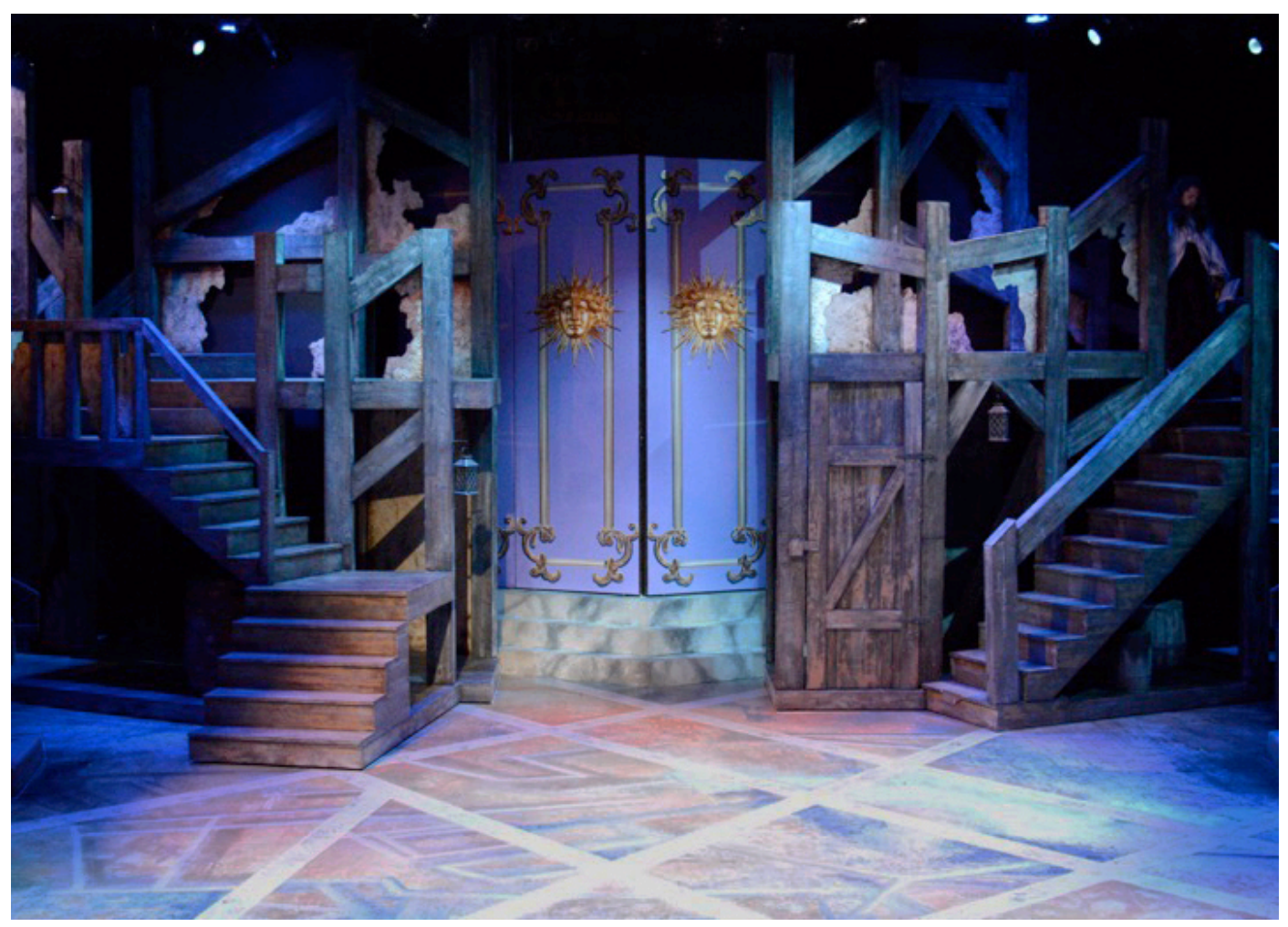

Transition to Act 1, Scene 11 


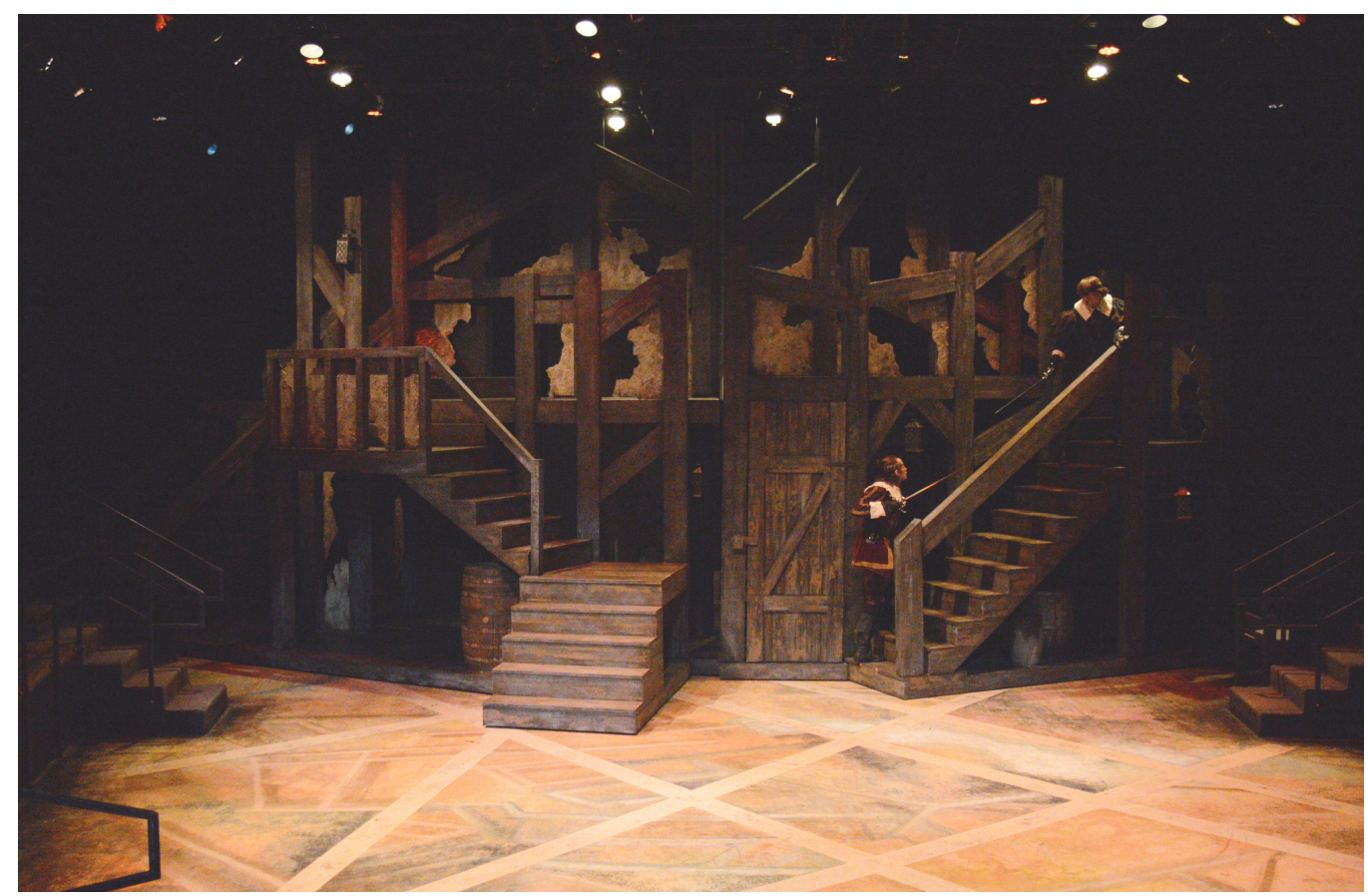

Act 2, Scene 8: D’Artagnan and Rochefort Duel on the Wagons

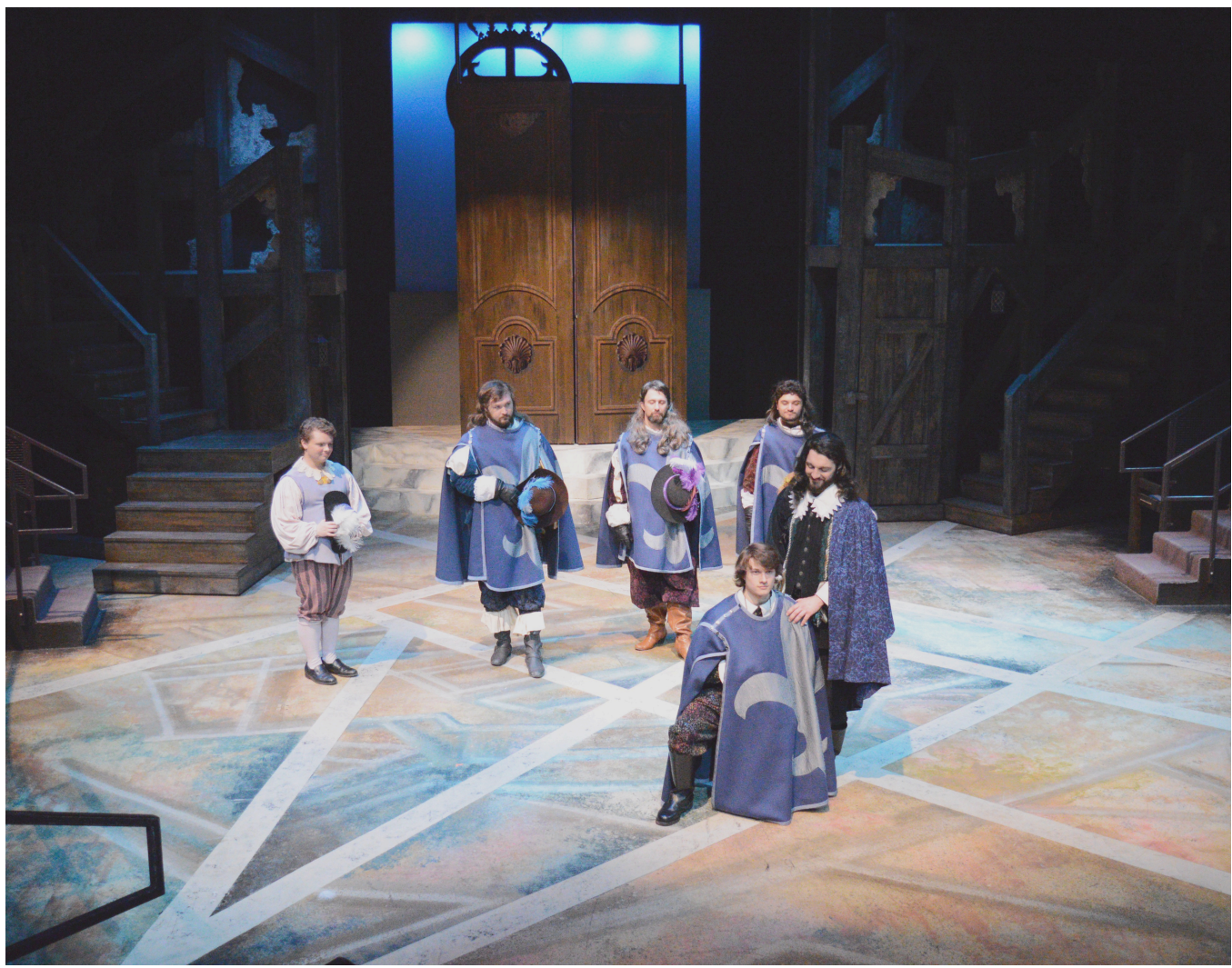

Act 2, Scene 9: D’Artagnan Becomes a Full-Fledged Musketeer 


\section{Bibliography}

Admin, Ewhelan and Eric Lambrecht. "How Did Cardinal Richelieu Change France?" DailyHistory.org,https://dailyhistory.org/How_did_Cardinal_Richelieu_change_France 3F. Accessed December 2017.

Bush, Catherine. The Three Musketeers. 2015.

D’Avella, Kaitlin. "Exploring Paris' Elegant Palais Royal." TripSavvy, https://www.tripsavvy.com/exploring-paris-elegant-palais-royal-1618628. Accessed December 2017.

Rose, Simon and Avi Abrams. "Totalitarian Architecture of the Third Reich." Dark Roasted Blend: Weird and Wonderful Things, http://www.darkroastedblend.com/2009/02/totalitarian-architecture-of-third.html. Accessed December 2017.

SparkNotes Editors. "The Three Musketeers: Further Study." SparkNotes LLC, https://www.sparknotes.com/lit/3musk/context/. Accessed December 2017.

The Editors of Encyclopaedia Britannica. "Albert Speer: German Architect and Nazi Official." Encyclopaedia Britannica, Inc., https://www.britannica.com/biography/Albert-Speer. Accessed December 2017. 